\title{
INFLUÊNCIA DO REMANESCENTE DENTÁRIO CORONAL NA AVALIAÇÃO DE DENTES TRATADOS ENDODONTICAMENTE RESTAURADOS COM PINOS PRÉ-FABRICADOS E RESINA COMPOSTA
}

JEFFERSON RICARDO PEREIRA

Dissertação apresentada à Faculdade de Odontologia de Bauru da Universidade de São Paulo, como parte dos requisitos para obtenção do título de Mestre em Odontologia - Área de Reabilitação Oral.

BAURU-SP

2003 


\section{INFLUÊNCIA DO REMANESCENTE DENTÁRIO CORONAL NA AVALIAÇÃO DE DENTES TRATADOS ENDODONTICAMENTE RESTAURADOS COM PINOS PRÉ-FABRICADOS E RESINA COMPOSTA}

JEFFERSON RICARDO PEREIRA

Dissertação apresentada à Faculdade de Odontologia de Bauru da Universidade de São Paulo, como parte dos requisitos para obtenção do título de Mestre em Odontologia - Área de Reabilitação Oral.

Orientador: Prof. Dr. Accácio Lins do Valle

BAURU-SP

2003 


\section{JEFFERSON RICARDO PEREIRA}

27 de julho de 1978

Nascimento

São Paulo - SP

Maurício de Jesus Pereira

Filiação

Elaine Maria Marques Pereira

Curso de Odontologia - Faculdade de Odontologia de

1996-1999

Bauru - USP

2000

Estágio no Departamento de Prótese da Faculdade de Odontologia de Bauru - USP

Curso de Pós-Graduação em Reabilitação Oral em

$2001-2002$ nível de Mestrado, na Faculdade de Odontologia de Bauru - USP.

SBPqO - Sociedade Brasileira de Pesquisas

Associações

Odontológicas.

IADR - International Association of Dental Research. 


\section{DEDICATÓRIA}

Aos meus pais, Maurício e Elaine, dos quais o exemplo e o amor fizeram-me chegar aonde cheguei e, com certeza, levará muito além.

À minha irmã Marcelle, pelo seu companbeirismo, amizade, amor e confiança, características que sempre me impulsionaram, até nos momentos mais dificeis.

A Deus, por sempre me mostrar o caminho que devo tomar em todas as decisões de minha vida e nunca me abandonar.

\section{Dedico a vocês este trabalho.}




\section{“O primeiro passo para você atingir uma meta é convencer-se de que é capaz disto."}

Júlio Lobos 


\section{AGRADECIMENTOS ESPECIAIS}

Aos mens pais, Maurício e Elaine, por seu carinho, amor e amizade. Se en devo alguma coisa por ter chegado até aqui, eu devo isto a vocês. Muito obrigado pelo grandioso amor e pela esperança que vocês sempre me transmitiram.

A minha Irmã, Marcelle, obrigado por ser a amiga maravilhosa que é, sem sua força tudo que consegui não seria possivel.

A Deus por ser meu companheiro de todas as horas.

Aos meus avós, tios e primos que sempre confiaram e torceram por mim.

Ao meu ORIENTADOR Prof. Dr. Accácio Lins do Valle, pela orientação feita neste trabalho e pela sua ajuda em todos os momentos necessários durante todo o tempo que trabalhamos juntos e ao meu AMIGO Accácio, o qual, a cada dia que passa, impressiona-me ainda mais, pela sua bumildade, amizade e companheirismo. A confiança que deposita em minha pessoa nunca será em vão, obrigado por tudo. 
Aos meus AMIGOS Alessandro, Paul $e$ Heitor que durante 6 anos foram minha familia aqui em Bauru. Sempre estiveram presentes, nos momentos felizes e tristes, comemorando ou consolando, obrigado por tornar este periodo de minha vida memorável.

Ao Rafael por ser minha família aqui em Bauru agora, ter que me agüentar 24 horas por dia e ser, a cada dia que passa, ainda mais men AMIGO. Obrigado por mostra-me que posso contar com você.

A Andreza, Carla $e$ João Paulo por sempre estarem ao meu lado, a amizade de vocês nós torna muito mais do que amigos, nos tornam irmãos. Obrigado por ser assim.

\section{AGRADEÇO DO FUNDO DO CORAÇÃO}




\section{AGRADECIMENTOS}

Ao Prof. Dr. Paulo César Rodrigues Conti, pela orientação

da minha primeira iniciação cientifica, a qual fez apaixonar-me pela pesquisa e seguir o caminho que escolbi e ao amigo Continho que mostrou ser muito mais do que um ótimo professor, mostrou ser um grande amigo, que posso recorrer sempre que precisar. Obrigado por sempre acreditar em mim.

\section{Ao Prof. Dr. Gerson Bonfante e Prof. Dr. Luiz}

Fernando Pegoraro pela disposição e interesse na transmissão de seus conhecimentos e por auxiliar-me em todos os momentos que precisei. Muito Obrigado.

Ao Murilo, por ser uma pessoa da qual a humildade deveria ser tomada como exemplo. Obrigado por ter me auxiliado grandemente na elaboração deste trabalho, por fazer parte de minha vida agora, e mostra-me que não ganhei só mais um companheiro de trabalho e sim um AMIGO.

Aos meus amigos Celso, Lula, Marcelo Sperandio e Renato (Gini) por estarem sempre dispostos a me ajudar e participarem, de forma tão marcante, da minha vida acadêmica e pessoal. Obrigado por serem meus 
grandes amigos.

Aos meus colegas do Mestrado: Luciana, Tatiany, Osvaldo, Paulo, Mauro, Stela, Mariana, e Leylha pela amizade, companheirismo compartilhado durante todo o curso e pela troca de conhecimentos dos quais só nos engrandecemos. Obrigado.

Aos colegas de Doutorado: Juliano, Rudys, Vinícius, Barnabé, Carlinhos, Nelsinho, Gildo, Stefania e Anuar pelos momentos compartilhados durante esta etapa de minha vida. Em especial ao Juliano por me ajudar em vários momentos deste curso.

Ao Kleber $e$ Norberto muito obrigado por serem meus amigos $e$ ter, de alguma forma, ajudado-me a chegar até aqui.

Ao Chico (Mestrado Interinstitucional) pela disposição em ajudar me na elaboração deste trabalho.

Aos Professores do Departamento de Prótese Paulo Martins Wellington, Salvador, Renato, Rubo, Lucimar, Carlos Araújo e José Conti pelos ensinamentos transmitidos durante toda a minha formação acadêmica. 
Aos funcionários do Departamento, em especial a Edna, Cláudia,

Débora, Riva, Marcelo, Luzia $e$ Valquiria sempre torcendo por mim e dispostos a ajudar-me em qualquer momento que precisasse. Obrigado.

Aos funcionários da Pós-Graduação, pela dedicação em sempre atender minhas necessidades, especialmente a Dona Ana, Cleuza, Aurélio $e$ Giane.

Aos funcionários da biblioteca pela disponibilidade que sempre me foi prestada. Especialmente à Valéria pela ajuda na correção das referências desta dissertação.

Aos estagiários Estevam, Samara, Jonas, Lucas, Érico, Valdey e Mikaela por sempre estarem prontos a ajudar-me. Muito obrigado.

Aos colegas de todo o Mestrado, pelos momentos de alegria que passamos juntos.

Ao Prof. Dr. José Roberto Pereira Lauris pela ajuda na estatistica deste trabalho.

À Faculdade de Odontologia de Bauru - Universidade de São Paulo, 
representada por sua Diretora Profa. Dra. Maria Fidela de Lima Navarro.

A CAPES, o seu apoio financeiro fez possivel a realização deste trabalho.

Ao Governo do Estado de São Paulo que através de sua faculdade a FOB-USP fez com que fosse possivel realizar o meu sonbo: tornar-me Cirurgião Dentista e agora Mestre.

A todas aquelas pessoas que de alguma forma, diretamente ou indiretamente, colaboraram com esta conquista

\section{Meus sinceros agradecimentos}




\section{SUMÁRIO}

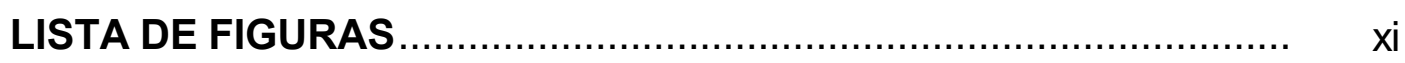

LISTA DE TABELAS ........................................................... $\quad$ iii

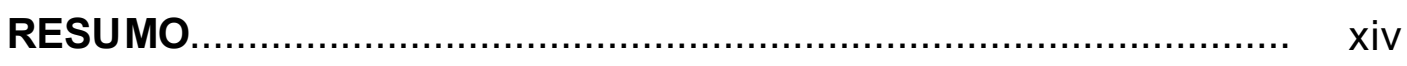

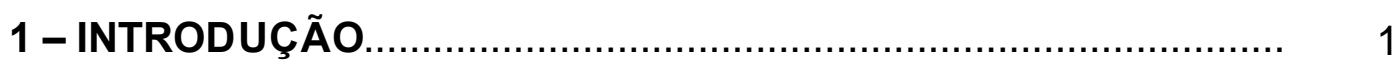

2 - REVISÃO DE LITERATURA ............................................. 8

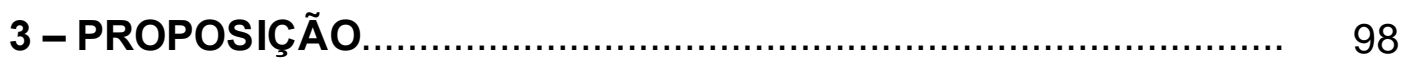

4 - MATERIAL E MÉTODOS .................................................. 100

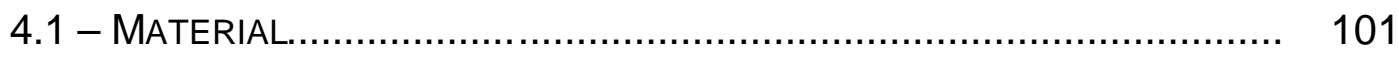

4.2 - MÉTODO.................................................................. 102

4.2.1 - SeleÇÃo dos Dentes, LimpeZa e ARMAZENAMENTO................... 102

4.2 .2 - TRATAMENTO ENDODÔNTICO.............................................. 103

4.2 .3 - DISTRIBUIÇÃO DOS GRUPOS.............................................. 104

4.2.4 - PREPARO DOS DENTES.................................................... 105

4.3 - PREPARO DOS CONDUTOS.................................................... 106

4.4 - OBTENÇÃO dOS NÚCLEOS METÁLICOS FUNDIDOS........................... 108

4.5 - CimentaÇÃo dos PinOS PRÉ-FABRicados e Núcleos Metálicos FUNDIDOS

4.6 - CONFECÇÃO dOS NúCLEOS DE PREENCHIMENTO......................... 112

4.7 - INCLUSÃO DOS DENTES....................................................... 114

4.8 - ENSAIO DE RESISTÊNCIA À FRATURA................................... 114

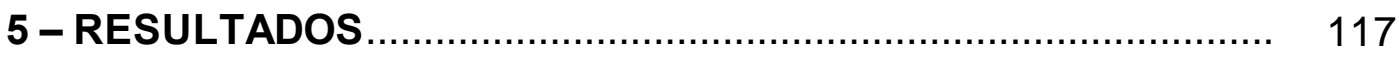

6 - DISCUSSÃO.............................................................. 122

7 - CONCLUSÕES............................................................. 135

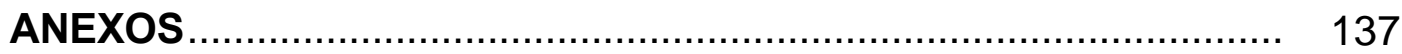

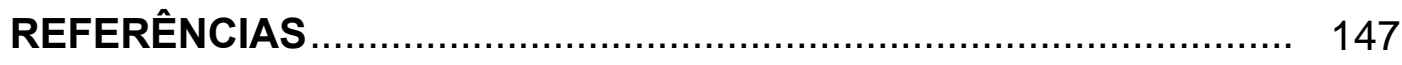

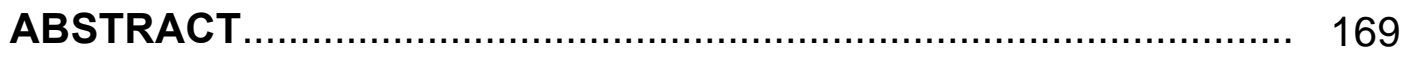




\section{LISTA DE FIGURAS}

FIGURA 1: Preparos dos dentes sem remanescente coronário (a-c).........105

FIGURA 2: Preparo dos dentes com remanescente coronário. .106

FIGURA 3: Confecção das matrizes de polietileno (a-b). 109

FIGURA 4: Núcleo metálico fundido e liga de cobre/alumínio. 110

FIGURA 5: Cimentação dos pinos intra-radiculares (a-b).

FIGURA 6: Confecção dos núcleos de preenchimento (a-d) 113

FIGURA 7: Esquema da aplicação de força à 45ํ(a-b). 115

FIGURA 8: Visualização do aparato utilizado para a fixação e posicionamento dos corpos de prova submetidos ao teste de resistência à fratura em uma Máquina de Ensaios Universal (a-d). 116

FIGURA 9: : Representação gráfica das médias de resistência à fratura dos seis grupos experimentais 121

FIGURA 10: Sem pino intra-radicular (1-10) 140 
FIGURA 11: Núcleo metálico fundido (1-10).

FIGURA 12: Pino pré-fabricado sem remanescente dentário coronal $(1-10)$ 142

FIGURA 13: Pino pré-fabricado com $1 \mathrm{~mm}$ de remanescente coronal $(1-10)$ .143

FIGURA 14: Pino pré-fabricado com $2 \mathrm{~mm}$ de remanescente coronal $(1-10)$ 144

FIGURA 15: Pino pré-fabricado com $3 \mathrm{~mm}$ de remanescente coronal $(1-10)$ 145 


\section{LISTA DE TABELAS}

TABELA 1: Material de consumo utilizado.

.101

TABELA 2: Teste estatístico de análise de variância a um critério aplicado aos valores de resistência à fratura

TABELA 3: Comparações individuais das médias - Teste de Tukey 119

TABELA 4: Valores individuais, médias e respectivos desvios-padrão para cada condição experimental (valores em kgf.) 120

TABELA 5: Padrão de fraturas 138

TABELA 6: Porcentagem dos tipos de falhas encontradas para cada grupo. .139 


\section{RESUMO}

O objetivo deste trabalho foi analisar a influência da quantidade de remanescente dentário coronal sobre a resistência de dentes tratados endodonticamente. Para isto foram selecionados 60 caninos superiores humanos anatomicamente semelhantes, divididos em seis grupos de dez espécimes cada, sendo que o grupo I não recebeu pino intra-radicular, o grupo II foi restaurado com núcleos metálicos fundidos e os grupos 3, 4, 5 e 6 foram restaurados com pinos pré-fabricados intra-radiculares e resina composta com diferentes quantidades de remanescentes dentários coronais de 0, 1, 2 e $3 \mathrm{~mm}$, respectivamente. Após serem restaurados os dentes foram levados a Máquina de Ensaios Universal para os testes de compressão a 45․ A análise dos resultados (ANOVA, $p>0,05$ ) mostrou haver diferença estatisticamente significativa entre os grupos. O teste de Tukey encontrou valores de resistência à fratura significativamente mais elevados para os núcleos fundidos, seguido dos pinos pré-fabricados sem remanescente coronal. Os outros grupos se apresentaram com valores inferiores muito próximos entre si, mostrando, desta forma que o remanescente dentário coronal influencia de maneira pouco significativa a resistência dos dentes tratados endodonticamente.

Palavras-chave: resistência, pino, núcleo, resinas compostas. 
1 INTRODUÇÃO 


\section{INTRODUÇÃO}

O princípio fundamental da Odontologia é a manutenção e restabelecimento da saúde bucal, tendo como lugar de destaque a prevenção, a qual procura manter as condições naturais de saúde do ambiente bucal, prevenindo-o de qualquer patologia. No entanto, quando estas alterações estão presentes, deve-se procurar restabelecer as condições de normalidade buscando um correto diagnóstico e a inter-relação entre as várias disciplinas da Odontologia para que se obtenha o sucesso do tratamento.

A odontologia restauradora objetiva restabelecer a forma, a função e a estética desse sistema. Para tanto, é de imensa importância o conhecimento de diversos assuntos tais como a doença cárie e a sua relação com as estruturas adjacentes, o domínio de técnicas restauradoras, o conhecimento de inúmeros materiais disponíveis, suas características, propriedades e comportamento clínico para que sua indicação seja correta e precisa.

A terapia endodôntica tem preservado dentes que de outra forma estariam irremediavelmente perdidos. Todavia, esta terapia atua somente na porção radicular destes dentes, restando o problema da restauração coronária para restabelecê-los como elementos permanentes e funcionais do sistema estomatognático ${ }^{44}$. A perda da estrutura coronal em dentes destruídos requer a utilização do canal radicular para suportar a restauração ou coroa.

A reconstrução da parte coronária de um dente despolpado teve seu i- 
nício por volta de 1746 com PIERRE FAUCHARD ${ }^{40}$, utilizando um pino de madeira no interior do conduto com a função de reter a coroa, na tentativa de devolver a estética ao paciente.

A partir deste momento, o tratamento para os dentes que se encontravam nesta situação se baseou na confecção de núcleos intra-radiculares com o propósito de reforçar o dente estruturalmente comprometido e prover retenção a futura restauração ${ }^{37,71}$. Entretanto, alguns autores defendem a idéia de que quando não houver grande perda de estrutura dentária a utilização de um pino torna-se desnecessária $4,31,47,51,154$.

Durante muitos anos o método restaurador de eleição para um dente despolpado tem sido os núcleos metálicos fundidos ${ }^{44,68,106,131}$, os quais têm demonstrado altas taxas de sucesso ao longo dos anos ${ }^{15}$ possuindo como principal vantagem a considerável documentação cientifica, que comprova sua efetividade, boa adaptação a configuração dos canais e resistên$\operatorname{cia}^{16,47,106,111,146}$.

Com o desenvolvimento de novas técnicas e materiais começaram a surgir novas alternativas para o tratamento de dentes tratados endodonticamente como, por exemplo, os pinos intra-radiculares pré-fabricados e materiais de preenchimento tal como as resinas compostas $9,10,41,97,142$.

Apesar de núcleos fundidos serem freqüentemente usados, há uma forte tendência no aumento do uso de sistemas pré-fabricados ${ }^{9,94,99}$. MORGANO ${ }^{99}$ cita que os pinos pré-fabricados têm sido preferidos pela grande maioria dos profissionais norte americanos em detrimento ao uso dos pinos metá- 
licos fundidos. No entanto, a falta de conhecimento sobre as técnicas e características ideais para a sua utilização, acompanhado da ausência de um protocolo de trabalho, vem causando problemas na clínica odontológica.

De acordo com MONDELLI ${ }^{96}$ o dente despolpado apresenta uma menor resistência em relação ao dente vital principalmente pela extensa perda de dentina, tecido este resiliente que confere, ao dente, resistência elástica. Esta perda de dentina pode ser ocasionada pela presença de um estado patológico (cárie, erosão, abfração) ou trauma (fratura dentária), como também pelo próprio tratamento endodôntico ao se efetuar uma abertura coronária para a abordagem dos condutos. Nos casos de coroas parcialmente destruídas deve-se manter o máximo possível de estrutura coronária remanescente com o objetivo de alcançar maior magnitude de retenção e de absorção de cargas mastigatórias. Outros autores sugerem que esta fragilidade esteja relacionada à perda de umidade da dentina após o tratamento endodônti$\mathrm{CO}^{5,14,37,41,50,70,120,152}$.

Conceitualmente, um pino é usado para providenciar retenção a um núcleo ou a uma coroa e aumentar a força do dente contra fratura ${ }^{9,10,81,131}$. Pode não haver questão de que um pino providencia retenção a uma coroa, no entanto, parece não haver evidências substanciais que afirmam que pinos cimentados aumentam a força de dentes tratados endodonticamente. Inúmeros autores $5,48,62,88,110,136,147,154,158$ têm demonstrado que este método não devolve a resistência à fratura que um dente vital possui, devido à própria fragilidade do dente, à diminuição da retenção, ao efeito de cunha que 
este tipo de restauração causa e às diferentes propriedades físicas entre o metal e o dente. Outros autores ${ }^{19,22,154}$ sugerem, ainda, que o pino pode até enfraquecer o dente.

HENRY, P. J. ${ }^{55}$, em 1977, mostrou que quando se optou pela manutenção da estrutura coronária houve uma mínima concentração de estresse, sendo distribuída mais uniformemente por todo o dente.

SORENSEN, J. A $^{137}$, em 1988, observou que apesar de existir uma forte evidência de que pinos não reforçam um dente tratado endodonticamente, cirurgiões dentistas continuam a utilizá-los com este propósito.

A decisão em relação ao tipo de restauração e materiais a serem empregados é determinada pela avaliação da condição do próprio dente. MORGANO $^{98}$, em 1996, defendeu que a utilização de um pino intraradicular deveria ser indicada somente para dentes deficientes coronalmente com o objetivo principal de retenção do núcleo.

ASSIF; GORFIL ${ }^{5}$, em 1994, e MANNING et al. ${ }^{84,85}$, em 1995, afirmaram que a resistência à fratura de dentes tratados endodonticamente tem relação direta com a quantidade de remanescente dentário e concluíram que quando existe perda de estrutura dentária prévia como resultado de cáries, restauração prévia, fratura ou acesso endodôntico os dentes tornam-se mais vulneráveis às forças que atuam sobre eles.

Uma dúvida ainda permanece em relação ao tipo de restauração e material que devem ser utilizados quando dentes tratados endodonticamente 
perderam parte de seu remanescente dentário coronal.

Em 1990, SORENSEN, J. A. ${ }^{138}$ comentou que o ganho de pelo menos $1 \mathrm{~mm}$ de estrutura coronal entre o término da coroa e a junção núcleo/dente aproximadamente duplicou a resistência a fratura. $O$ mesmo autor ${ }^{139}$, neste mesmo ano, chegou a conclusão de que não houve nenhuma correlação entre estrutura dentária coronal remanescente e a resistência à fratura.

No trabalho realizado por ISIDOR, F. et al. ${ }^{\mathbf{6 6}}$, em 1999, foram utilizados 90 raízes divididas em nove grupos de dez cada, todas restauradas com pinos pré-fabricados intra-radiculares variando-se o comprimento do pino e a quantidade de remanescente coronal. Todos os dentes receberam núcleos de resina composta e posteriormente coroas. Aplicourse uma carga de 400 kgf a uma angulação de 45ำ em relação ao longo eixo do dente. Observour se que quanto maior a quantidade de remanescente coronal dentário maior foi a resistência a fratura. Conclui-se que o efeito do remanescente coronal foi muito mais importante que o comprimento do pino em relação à resistência a fratura.

São freqüentes as fraturas de dentes tratados endodonticamente, razão pela qual são importantes o conhecimento, a compreensão e a interpretação dos princípios biomecânicos aplicados às restaurações para que possa coletar técnicas que ofereçam, com segurança, resistência e retenção aos elementos dentários naquelas condições. Pela falta de informações na literatura corrente de qual seria a quantidade de estrutura dentária coronal remanescente suficiente para obtemos o sucesso do tratamento em longo 
prazo, estudaremos se sua variação influencia na resistência a fratura de dentes tratados endodonticamente. 
2 REVISÃO DE LITERATURA 


\section{REVISÃO DE LITERATURA}

O uso do remanescente radicular como suporte para restaurações protéticas foi pela primeira vez relatado por PIERRE FAUCHARD ${ }^{40}$, em 1728, que utilizou um pino de prata inserido no canal radicular com o objetivo de conseguir retenção para as futuras coroas de espiga. No entanto, existe evidências que mostram que este experimento foi primeiramente realizado pelos japoneses, no século VII, substituindo dentes perdidos por coroas com pinos de madeira.

Em 1869, BLACK ${ }^{17}$ idealizou uma técnica de aproveitamento de raiz através de uma coroa de faceta de porcelana com uma rosca que era fixada dentro do canal, o qual era preenchido com ouro em folha.

As coroas de RICHMOND, mais conhecidas como "pivot", surgiram no final do século XIX. Eram coroas protéticas que possuíam prolongamentos que se encaixavam perfeitamente no interior do conduto radicular, pois eram confeccionadas a partir de modelos de gesso obtidos através de um material de moldagem que copiava fielmente o interior do conduto. No entanto, apesar de ser largamente utilizada nesta época apresentavam algumas desvantagens como dificuldade de remoção, freqüentes fraturas radiculares e grande dificuldade de se conseguir paralelismo entre os retentores. Devido a estes problemas, seu uso foi gradualmente abandonado, dando lugar aos núcleos intra-radiculares, formados por um pino de fixação no conduto 
radicular preparado e de uma porção coronária com forma anatômica de um dente preparado, na qual era colocada uma coroa com faceta estética. Com o uso dos núcleos intra-radiculares, facilitou-se a remoção da coroa quando necessária bem com o paralelismo entre os diversos suportes.

BOVE $^{157}$ em 1941, (apud VALLE) ${ }^{*}$ afirmou que, por volta de 1840, na Inglaterra, dentes com formato de tubos com perfurações em toda a sua extensão associados a espigas de madeira eram utilizados para a restauração de dentes despolpados. Citou ainda que CLARK em 1844, modificou esta idéia substituindo o tubo de madeira por um de metal, propiciando um a umento na resistência da restauração.

MARKLEY ${ }^{87}$, em 1958, sugeriu a utilização de pinos para retenção de reconstruções de amálgama. Segundo o autor, o amálgama bem condensado apresenta resistência à compreensão comparável com a da dentina, podendo ser utilizado também na confecção de núcleos de preenchimento. Dessa forma, a associação de pinos intradentinários ou intra-radiculares com reconstruções com amálgama pode ser um método para salvar dentes ou raízes que normalmente seriam sacrificadas.

A partir desta época vários estudos começaram a analisar este elemento restaurador. SILCKEMORE ${ }^{129}$, em 1959, afirmou que as coroas com pinos intra-radiculares eram um método muito comum, porém passíveis de freqüentes insucessos, como fratura do pino, devido a falta de resistência do material empregado. 
BAKER $^{7}$, em 1960, comentou que uma coroa de espiga apresentava o mesmo sistema de retenção mecânica que um dente no alvéolo e poderia fornecer melhor retenção que as coroas cimentadas em dentes vitalizados, permitindo assim sucesso em longo prazo.

TYLMAN; TYLMAN ${ }^{156}$, em 1960, descreveram uma técnica onde empregaram pinos lisos e com roscas nos condutos radiculares, completados com cera na sua porção coronária dando forma de um "coping" que cobria totalmente a raiz com o objetivo de reforçá-la. Eram, então, fundidos para que sobre eles fossem colocadas coroas de porcelana.

Realizando uma ampla revisão de literatura, ROSEN ${ }^{120}$, em 1961, preocupou-se em estabelecer normas para a correta reconstrução de dentes fragilizados e tratados endodonticamente alertando que a perda de umidade decorrente do tratamento endodôntico, que torna a dentina friável e inelástica. Além disso, considera a facilidade com que esses dentes desenvolvem lesões periapicais. Recomendando procedimentos que reforcem o dente indica a confecção de núcleos metálicos fundidos e coroa protética abraçando o término gengival, prevenindo com isso a ocorrência de fraturas sob cargas mastigatórias, o que poderia resultar no aumento da sua longevidade.

A necessidade de reforço de pinos metálicos foi salientada por BRECKER $^{20}$, em 1961, sugerindo a preservação de estrutura sadia quando da sua utilização, pois acreditava que quanto maior o remanescente dental maior seria a resistência do pino. 
Desde que o comprimento do pino fosse correspondente a 2/3 do comprimento da raiz, SEGAT ${ }^{126}$, em 1962, aconselhou o uso de coroas de espigas ou pivôs, confeccionados em ouro e faceta estética de resina. Enfatizou também que em hipótese alguma o tamanho do pino poderia ser menor que o tamanho da coroa.

HOLT $^{61}$, no mesmo ano, reafirmou que o comprimento do pino é o responsável pelo sucesso dos núcleos metálicos, não devendo ser nunca menores que o tamanho das coroas.

SILVERSTEIN ${ }^{131}$, em 1964, escreveu sobre o reforço de dentes despolpados enfraquecidos. Comentou que, devido ao tratamento endodôntico, os dentes tornam-se fracos e propensos a fraturas. Portanto os dentes tratados endodonticamente precisariam de um reforço para que pudessem atuar de forma eficiente. $O$ autor relatou sobre as vantagens da confecção de um núcleo intra-radicular quando comparado a uma coroa com espiga, salientando a importância do núcleo não ser parte integral da coroa. Descreveu ainda uma técnica direta para a obtenção de núcleos metálicos à partir de um padrão de fundição, confeccionado pela moldagem do conduto com um pino de resina acrílica e cera e obtenção da porção coronária pelo auxilio da coroa provisória.

Em 1965, CHARLTON ${ }^{26}$ enfatizou que o método de escolha dos profissionais da época para restauração de dentes destruídos e com tratamento endodôntico era a colocação de um pino fundido, sobre o qual era cimentada uma coroa de jaqueta. Afirmava também que esta técnica era dispendiosa e 
trabalhosa. Sugeriu a utilização de pinos pré-fabricados por serem de fácil utilização e mais acessíveis em termos de custo ao profissional. Referindo-se à retenção dos núcleos metálicos, o mesmo deveria ter no mínimo o tamanho da coroa para que mecanicamente pudesse ter uma boa retenção. 0 cimento durante a cimentação deveria ser colocado tanto no pino quanto no interior do conduto e um cuidado especial deveria ser tomado no posicionamento do pino, pois ele poderia agir como um embolo por ação da pressão hidrostática, não permitindo, assim, um adequado assentamento.

Descrevendo que a obtenção de núcleos metálicos fundidos poderia ser feita pela técnica direta ou indireta com o mesmo sucesso e que o comprimento do pino deveria ser pelo menos igual ao tamanho da futura coroa, JOHNSTON et al. ${ }^{67}$, em 1965, enfatizaram que todos os dentes tratados endodonticamente são mais propensos à fratura quando comparados aos dentes polpados, devendo, assim, serem reforçados com pinos metálicos.

Em 1967, CHRISTY e PIPKO et al. ${ }^{29}$, verificaram que uma coroa cimentada sobre um núcleo em dois estágios, pino e núcleo de preenchimento, seria o tratamento adequado para um dente tratado endodonticamente, preenchendo os princípios biomecânicos de desenho, função e estética, além de gastar pouco tempo clínico e ser um procedimento simples. Os autores afirmaram que se deve preservar, ao máximo, estrutura dentária ao preparar a porção radicular para receber o pino metálico podendo atingir de dois terços a três quartos do remanescente radicular. 
Analisando a falta de retenção dos pinos metálicos dentro do conduto e a grande quantidade de desgaste de dentina, KURER ${ }^{76}$, em 1967, preconizou o uso de pinos rosqueáveis e parafusados com melhores resultados quando comparados aos núcleos fundidos.

RUSSI; LEONARDI ${ }^{122}$, em 1968, afirmaram que a correta execução de uma coroa com pino deve obedecer basicamente a três princípios: a) correto tratamento do canal radicular; b) não pode ser colocado em presença de lesão periapical; c) o pino deve ter um tamanho de no mínimo 2/3 do comprimento da raiz. Pesquisando radiograficamente trabalhos com coroas de espiga, encontraram que $95,2 \%$ dos casos apresentavam relação incorreta entre o comprimento do pino e tamanho da raiz.

Preocupado com a qualidade de obturação dos condutos que iriam receber pinos metálicos, NEAGLEY ${ }^{101}$, em 1969, avaliou os diversos tipos de selamento. Estes foram realizados com: a)cones de prata; b) cones de gutapercha com condensação lateral; c) cones de guta-percha aquecida e; d) obturação retrógrada. Os condutos foram preparados com 4 a 8mm de remanescente obturador e corados com solução de Rhodamine-B. Concluíram que os condutos obturados com guta-percha com condensação lateral e guta-percha aquecida, não permitiram a penetração do corante. A obturação retrógrada e cones de prata não foram tão efetivos.

Em 1969, FUSAYAMA; MAEDA ${ }^{45}$, testaram o efeito da remoção do tecido pulpar e observaram que este procedimento não diminui a dureza da dentina, mas cessa o crescimento e maturação do dente jovem, resultando 
em uma dentina mais delgada e enfraquecida quando comparada com um dente integro. Os autores utilizaram quarenta caninos de dez cachorros. As polpas de 20 caninos direitos foram removidas e os outros 20 caninos esquerdos foram mantidos intactos como grupo controle. Doze dos vinte canais foram restaurados imediatamente com guta-percha. Os canais remanescentes foram mantidos abertos. Os cachorros foram sacrificados após 4, 6 ou nove meses. Oito pares de caninos foram usados. Para determinar a dureza da dentina foi usado um indentor Knoop, em regiões determinadas. Os resultados obtidos mostraram que a dureza e a espessura dos dentes tratados endodonticamente eram menores do que o grupo controle.

SHEETS $^{127}$, em 1970, descrevendo uma série de princípios que considerava essenciais na restauração de dentes despolpados, concluiu que os núcleos metálicos fundidos foram os que apresentaram os melhores resultados.

SHILLINGBURG JUNIOR; FISHER; DEWIRST ${ }^{128}$, em 1970, indicaram os núcleos fundidos para dentes sem remanescente coronário, tanto para dentes uni como multirradiculares, devendo-se sempre aproveitar a raiz mais volumosa ou o canal mais amplo. Consideraram também que 2/3 a 3/4 seria a profundidade do conduto para estes pinos e que quando isto não fosse possível, o comprimento do pino deveria ter no mínimo metade do tamanho da coroa clínica. Outro fator importante a ser considerado seria o nível de obturação apical de $3 \mathrm{~mm}$, o que preveniria o deslocamento dos cones de guta-percha e, posteriormente, uma infiltração. Quando os dentes tratados en- 
dodonticamente não permitirem o uso de núcleos metálicos devido a canais curtos e atrésicos ou acentuadamente divergentes, indicaram a utilização de núcleos de preenchimento com amálgama retido a pinos para se conseguir suporte para uma restauração metálica fundida.

STANDLEE; COLLARD; CAPUTO ${ }^{144}$, em 1970, estudaram o comportamento das brocas nos preparos dos condutos que iriam receber núcleos fundidos, concluindo que elas provocaram o aparecimento de trincas nas paredes de dentina. Chamaram atenção também para quando da utilização de pinos rosqueáveis e retidos por fricção, a possibilidade de ação de cunha e fratura subseqüente. Na utilização de pinos cimentados, este risco de fratura quase não acontece.

Segundo HARRIS ${ }^{52}$, em 1970, a restauração de eleição para dentes tratados endodonticamente, destruídos por cáries, repetições de restaurações e fraturas, é uma coroa total. Quando a estrutura coronária está enfraquecida ou ausente, a raiz passa a ser o suporte para a restauração, por intermédio de núcleos metálicos fundidos em ouro. Comentando sobre pinos pré-fabricados afirmou que dentes com grandes destruições não são indicados para este tipo de tratamento.

Em 1970, BARABAN $^{9}$, descreve sobre a utilização de pinos préfabricados Para-post, em dentes tratados endodonticamente enfatizando vantagens do uso do método direto e de pinos metálicos confeccionados em ouro, aço inoxidável, plástico e alumínio. Os pinos de ouro e aço eram serrilhados para que houvesse maior rete nção do cimento, deve-se ter um 
cuidado especial com a cimentação destes pinos para que fosse possível evitar a formação de bolhas de ar, impedindo assim, desajustes nos pinos e até fraturas. A maior vantagem deste sistema é a obtenção de pinos e núcleos pelo método direto permitindo que todo o procedimento seja feito em uma única sessão.

Em 1971, SPALTEN ${ }^{142}$ sugeriu o uso de resina composta ao invés de amálgama para restaurar dentes com pinos dentinários. Ressaltou como propriedades, a boa adaptação, a resposta favorável da polpa com uma base de hidróxido de cálcio, baixa contração do material e um pequeno coeficiente de expansão térmica. Como vantagens mencionou a fácil manipulação, a resistência comparável com a estrutura dentária e resistência comparável ao amálgama. Comentou ainda que esta técnica reforça e esplinta a raiz mais facilmente que um núcleo metálico fundido e com menor esforço.

Em 1972, BARABAN ${ }^{10}$ preconizou a utilização do sistema Para-post e a fabricação do núcleo de preenchimento, com resina composta ativada quimicamente, para reconstrução da porção coronária em dentes uni e multirradiculares. Este tratamento economizaria tempo e material permitindo ainda o preparo imediato do dente, dispensando o trabalho de laboratório. $\mathrm{O}$ autor enfatiza a existência de suficiente retenção entre o núcleo de preenchimento e pino intra-radicular de resina durante os procedimentos subseqüentes e durante a função, não existindo mais a necessidade do uso de núcleos metálicos fundidos. 
Para PEREL e MUROFF ${ }^{106}$, em 1972, o preparo do acesso cavitário para tratamento endodôntico leva à remoção de estrutura dentária predispondo o dente às fraturas. Para sanar este problema indicaram o uso de um núcleo fundido, reforçando o conjunto raiz e porção coronária. Dentre os requisitos para o sucesso de tratamento com núcleos fundidos salientaram: 1) o pino deverá ser longo para prevenir o esforço interno excessivo na raiz; 2) o assentamento oclusal previne a ação de cunha, eliminando possível fratura da raiz; 3) a boa adaptação interna do pino distribuirá os esforços internos em toda sua extensão, além de proporcionar uma fina camada de cimento. Enfatizaram o perigo do uso de pinos rosqueados, como maior incidência de fratura a nível radicular.

Fazendo uma análise comparativa entre núcleos metálicos fundidos e pré-fabricados, HARTY e LEGGETT ${ }^{53}$, em 1972, comentaram que 0 deslocamento do pino é causado por forças de oclusão e mastigação agindo contra a coroa. Ressaltaram o fato de que apesar de ter sido demonstrado que os pinos com paredes paralelas são mais retentivos que os de paredes convergentes, os testes de laboratório exercem tração apenas no sentido do longo eixo do pino, fato este que não ocorre em função.

STANDLEE et $\mathbf{a l}^{\mathbf{1 4 5}}$, em 1972, analisaram três tipos de núcleos resumindo suas vantagens e desvantagens: 1) os núcleos lisos, paralelos, são bastante retentivos, porém de difícil cimentação devido à pressão hidrostática; 2) os núcleos lisos, de forma cônica distribuem bem o cimento, porém são os menos retentivos; 3) núcleos rosqueados com paredes 
paralelas são os mais retentivos, porém de difícil execução clínica. Os núcleos foram cimentados com cimento de fosfato de zinco, introduzidos no canal com broca Lentulo. $O$ pino foi recoberto com cimento e o assentamento foi feito digitalmente. Para evitar o deslocamento durante a cimentação, recomendaram a confecção de um sulco de escape ao longo do pino. Após a realização de uma análise fotoelástica da distribuição das forças durante a cimentação dos núcleos concluíram: a) o axioma clínico de que o comprimento do pino deva aproximar-se do comprimento da coroa anatômica para melhor distribuição de forças parece verdadeiro, visto que ocorreu uma redução na concentração de esforços com aumento do comprimento do pino; b) os núcleos rosqueados proporcionam melhor distribuição de esforços quando em pequenos comprimentos; c) os núcleos cônicos exibiram um efeito de cunha e produziram maior concentração de esforços na área cervical; d) os núcleos de paredes paralelas geraram as mais altas concentrações de forças apicais.

Preocupados com o alto índice de fraturas radiculares de dentes tratados endodonticamente e reconstruídos com núcleos metálicos fundidos STERN e HIRSHFIELD ${ }^{146}$, em 1973, observaram e afirmaram que estes dentes têm sua resistência diminuída e para que isto fosse minimizado alguns princípios durante os preparos dos condutos deveriam ser seguidos. Segundo os autores a profundidade do núcleo intra-radicular deve atingir cinqüenta por cento da distância entre o ápice radicular e a crista óssea alveolar para diminuir os fatores de risco. 
Formulando considerações gerais a respeito da confecção de núcleos para dentes tratados endodonticamente, SCHIMIDT et al. ${ }^{124}$, em 1973, descreveram uma técnica na qual utilizaram pinos pré-fabricados que eram adaptados aos condutos após serem tornados rugosos . A porção coronária era reconstruída com resina e o pino cimentado com fosfato de zinco ou policarboxilato.

A obtenção de núcleo de preenchimento com resina composta após cimentação de um pino pré-fabricado no conduto foi também descrita por FEDERICK ${ }^{41}$, em 1974, afirmando o autor ser esta uma técnica precisa, econômica e que tem apresentado sucesso em diversas situações clínicas.

KORNFELD ${ }^{75}$, em 1974, comentou o uso de pinos Parapost e Kerr endo-post na reconstrução de dentes despolpados, afirmando que o comprimento destes pinos deve ser pelo menos de $2 / 3$ da raiz, para se evitar possíveis fraturas.

Em 1975, BALASSIANO ${ }^{8}$ após extensa revisão de literatura, concluiu que o uso de pinos metálicos em dentes com grande destruição, tem sido a escolhido como meio de tratamento. Afirmou que novos conceitos são emitidos na tentativa de se buscar uma técnica ideal, enfatizando que na sua obtenção todas as fases são de grande importância: forma do pino, preparo do conduto radicular, comprimento, cimentação e material cimentante. Todos estes cuidados não teriam valor se o sucesso da terapia endodôntica não tivesse atingido um grau elevado, passando o dente tratado endodonticamente a ser considerado como um elemento capaz de suportar uma res- 
tauração individual ou ser retentor de uma prótese fixa. Dois tipos de pinos foram os mais encontrados na literatura: pré-fabricados e metálicos fundidos. Ambos são adaptados ao conduto radicular e devidamente cimentados. Quanto à forma, os pré-fabricados podem ser cônicos lisos, ranhurados e rosqueados. Os núcleos metálicos fundidos são aqueles esculpidos e fundidos para melhor atender à necessidade da restauração que se vai proceder. Considerou esta técnica como excelente, pois possibilita melhor adaptação do pino ao canal radicular e a porção coronária pode-se desviar do longo eixo da raiz para melhor desenho da restauração e paralelismo dos retentores.

MOYERS $^{100}$, em 1975, demonstrou a relação entre os dentes anteriores superiores e inferiores por meio de análise encefalométrica através de imagem radiográfica de perfil facial. Para o padrão normal de oclusão, o ângulo entre o incisivo central superior e inferior é de aproximadamente 135‥

YETTRAM et $\mathbf{a l}^{159}$, em 1976, analisaram a distribuição das tensões em dentes naturais e dentes restaurados com coroas protéticas sob carregamento vertical e oblíquo, através de modelos matemáticos, denominados de análise de elementos finitos. Os resultados demonstraram um importante papel do esmalte em distribuir as forças. Os carregamentos verticais tendem a se dissipar ao redor da estrutura de esmalte, enquanto que a dentina permanece com tensões relativamente baixas. $O$ esmalte próximo da junção amelo-cementária e altamente tencionado, e através dessa região transmite a maior parte das cargas para a raiz. Conseqüentemente, uma restauração que atinge esta região estaria 
submetida a alta tensão nesse mesmo local. Os autores sugerem que essas tensões poderiam ser responsáveis pela sensibilidade mediante a cimentação de coroas protéticas. A remoção do esmalte e colocação de uma coroa protética resultou em distribuição de tensões semelhantes às apresentadas pelo esmalte, onde as cargas se transmitem ao longo da coroa protética, ficando a parte central da dentina sujeita a um mínimo de tensões. Houve uma concentração de tensões na região gengival da raiz ligeiramente maior do que na coroa natural. Com isso, a linha de cimentação pode ser degradada com o tempo. Quando a carga foi aplicada obliquamente, as tensões sobre a dentina foram maiores que nos dentes naturais. Deste modo é recomendada pelos autores a confecção de coroas com planos cuspídeos menos inclinados, diminuindo a força de alavanca sobre o núcleo de dentina.

Segundo REIS ${ }^{116}$, em 1976, o grande progresso da endodontia em relação ao aprimoramento técnico-científico profissional abriu um novo campo ao protesista, por possibilitar o uso de novas técnicas de restauração para dentes nesta situação. Do "pivô" ao núcleo ocorreram mudanças gigantescas. O "pivô" teve sua época áurea. A época hoje pertence aos núcleos, que são mais simples e versáteis. A confecção dos pinos, sua adaptação depois de fundidos e sua relação com a raiz e coroa tornou-o um trabalho de alta precisão. A sua resistência ao deslocamento durante a mastigação é dada pela cimentação do pino dentro do conduto. Portanto a raiz e pino formam um único bloco, absorvem cargas mastigatórias de maneira homogênea e as distribuem aos tecidos de sustentação, sem prejudicá-lo. O autor concluiu afirmando que o preparo do remanescente coronário deveria ser fei- 
to em dois planos inclinados para os dentes anteriores, podendo ter variações para os posteriores. A profundidade do conduto deveria ser $2 / 3$ do tamanho total da raiz em dentes unirradiculares e para os multirradiculares estes $2 / 3$ deveriam estar presentes no conduto de maior calibre. $O$ método direto de obtenção do núcleo com resina acrílica ativada quimicamente é o mais indicado. Para dentes multirradiculares com raízes divergentes deve-se lançar mão de núcleos divididos, com encaixes de semiprecisão ou canaletas.

JOHNSON; SCHWARTZ; BLACKWELL ${ }^{68}$, em 1976 analisaram vários métodos e técnicas capazes de proteger a estrutura dental remanescente de fraturas, proporcionando melhor retenção e suporte às restaurações em dentes tratados endodonticamente. Afirmaram que os núcleos fundidos são mais resistentes às forças horizontais e verticais e quando são inseridos dentro do conduto transmitem as forças à raiz sem levá-la a fraturas. Sugeriram que os núcleos fundidos deveriam estar perfeitamente adaptados aos condutos, pois permitiriam uma distribuição uniforme de forças mastigatórias. O cimento deveria ser levado ao conduto por meio de uma broca Lentulo, para que se tenha uma camada uniforme sem espaços vazios. Aconselharam a confecção de sulcos ao longo dos núcleos, pois permitiria um melhor assentamento através do melhor escoamento do excesso de cimento.

CAPUTO e STANDLEE ${ }^{22}$, em 1976, ressaltaram, além da importância da retenção do pino a necessidade de preservar e proteger a dentina 
remanescente e a estrutura dentária. Os autores consideraram a utilização de núcleos intra-radiculares como uma técnica radical e caso houvesse erros poucas soluções corretivas poderiam ser empregadas. Destacaram que a maior retenção é dada com o aumento do comprimento do conduto, mas como fator de risco enfraqueceria a dentina. Concluíram que pinos com paredes paralelas, serrilhadas e cimentados com fosfato de zinco seria a melhor combinação para o sucesso da prótese.

BRAVIN $^{19}$, em 1976, analisou as cargas funcionais em 110 incisivos laterais superiores, utilizando quatro sistemas de núcleos pré-fabricados como reforço e um grupo controle (dentes íntegros). Os pinos foram cimentados com cimento de fosfato de zinco, com profundidade de 7 a $10 \mathrm{~mm}$, submetidos a forças oblíquas, cujos valores eram registrados quando ocorria a fratura do dente. Verificou que as fraturas do grupo controle sempre permitiam reparações e ocorriam sob ação de forças muito mais altas, enquanto os dentes com pinos sofriam fraturas irreparáveis. Concluiu que: 1) nenhum dos pinos testados reforçou os incisivos laterais e podem, ao contrário do que se pensava, enfraquecê-los; 2) o comprimento do pino foi estatisticamente significante - quanto mais longo, mais suporte; 3) a espessura de dentina emanescente entre o ápice do pino e a superfície dental mesial e distal, foi estatisticamente significante em relação á fratura dental; 4) se um pino for necessário, o Para-post em uma profundidade ideal foi o melhor de todos os testados; 5) o uso de pinos para suportar um dente restaurado endodonticamente apresenta um potencial para o fracasso. 
Estudando técnicas para restaurações de dentes despolpados, KANTOR e PINES ${ }^{71}$, em 1977, utilizaram dentes unirradiculares reunidos em quatro grupos: a) grupo controle - preparo dental padrão, sem reforço; 2) dente reforçado com pino de aço inoxidável, fixado ao conduto com cimento de policarboxilato; 3) núcleo metálico fundido em ouro e cimentado com cimento de policarboxilato; 4) pino de aço inoxidável cimentado com policarboxilato e porção coronária de resina composta. Estes pinos foram submetidos a uma força de compressão em $45^{\circ}$ na superfície vestibular, até que ocorresse a fratura. Concluíram que em dentes com a porção coronária intacta devido a uma boa terapia endodôntica, um pino cimentado dentro do conduto seria o tratamento de escolha, acreditando que a resistência do dente seria dobrada. Indicaram o uso de pinos metálicos fundidos para tratamentos complexos protéticos e periodontais.

DERAND ${ }^{36}$, em 1977, analisando a distribuição de forças em dentes em modelos experimentais, observou que quando as paredes dos condutos eram paralelas, a região cervical era atingida pela maior concentração de forças. Quando o contato entre o pino e o conduto era aliviado nesta região, a concentração dessas forças era reduzida. Diante destas observações destacou a importância de um alivio no pino e até nas paredes laterais do conduto para o seu melhor assentamento, reduzindo, desta forma, o risco de fratura e perda do pino.

Em 1977, GUTMANN ${ }^{49}$ recomendou que fossem observados quatro fatores básicos quando um dente precisasse ser reconstruído com a- 
juda de um núcleo metálico: 1) instrumentação adequada; 2) orientação em relação ao longo eixo da raiz; 3) comprimento adequado do preparo do conduto; 4) forma interna do conduto. Para uma melhor fixação do núcleo sugeriu que fossem confeccionadas retenções. Concluiu, afirmando que a preparação do conduto radicular para receber o núcleo é tão critica quanto a restauração final e que seu preparo deveria preservar a sua forma anatômica o que proporcionaria uma ótima situação para a distribuição das forças mastigatórias.

DALE; MOSER ${ }^{35}$, em 1977, testaram cinco ligas metálicas semipreciosas e uma áurea, utilizadas para confecção de núcleos metálicos fundidos, concluindo não haver diferenças significantes quanto ao padrão de adaptação de todas as ligas testadas, considerando-as clinicamente aceitáveis. Consideraram estas ligas ideais para confecção de núcleos, mas quando fossem utilizadas como restaurações definitivas, que se levasse em conta também sua resistência à corrosão e manchas, adaptação marginal e a capacidade de serem brunidas.

Em 1977, estudando a retenção de cinco marcas comerciais de pinos pré-fabricados com diferentes tipos de cimentos, KURER et al. ${ }^{77}$, encontraram uma resistência maior ao deslocamento axial quando o comprimento do pino era aumentado. O aumento do diâmetro dos pinos não teve efeito substancial na retenção, mas rugosidades promovidas por jatos de areia nos pinos aumentaram estes resultados consideravelmente. Os pinos metálicos fundidos não mostraram diferenças quando cimentados com qual- 
quer tipo de cimento. Afirmaram também que os pinos rosqueáveis possuem grande resistência ao deslocamento, mas que necessitam de um bom remanescente dentinário para o sucesso da restauração.

Em 1977, HENRY ${ }^{55}$, estudaram por meio de análise fotoelástica o estresse gerado, antes e após a aplicação de carga, em diferentes formas de pinos intra-radiculares. Foram estudados os pinos com: 1) Paredes divergentes; 2) Paredes paralelas; 3) Paredes paralelas e rosqueadas; 4) Paredes divergentes rosqueadas. Observaram que antes da aplicação de carga, os pinos cônicos e de paredes paralelas permaneceram sem áreas de concentração de força. Após a aplicação de carga, os pinos com paredes paralelas mostraram concentração de força em ambos os lados e os cônicos na região apical. Os de parede paralela foram mais favoráveis que os cônicos e os rosqueados apresentaram concentração de esforços tão grande que o autor considerou duvidosa sua aplicação clínica. Verificou também que a concentração de esforços diminuía quando existia um pequeno remanescente coronário, deixando a sugestão que este deva ser mantido quando formos confeccionar um núcleo.

Em 1978, TRABERT, CAPUT e ABOU-RASS ${ }^{153}$ realizaram um estudo para analisar a resistência de dentes tratados ou não endodonticamente e restaurados com o uso de pinos de aço inoxidável. Foram utilizados pinos de diâmetro, largura e comprimentos diferentes. Verificaram que os pinos com diâmetros menores preservam maior 
quantidade de estrutura dentária aumentando, assim, significativamente a resistência à fratura.

MILLER $^{93}$, em 1978, descreveu uma técnica para confecção de núcleos metálicos fundidos através de confecção de um padrão de resina acrílica na cavidade bucal. Descreve que o núcleo deve ter uma conicidade mínima, evitando desgaste de estrutura dental. Afirma que este método resulta em menor remoção de dentina do que utilizando pinos pré-fabricados cilíndricos, que diferem da anatomia do canal, resultando em remoção de dentina na porção mais apical do preparo.

Em 1979, GUZY e NICHOLLS ${ }^{\mathbf{1}}$, avaliaram o reforço da estrutura dental decorrente da utilização de pinos em dentes tratados endodonticamente. Foram selecionados 59 dentes recentemente extraídos, incisivos centrais e caninos, os quais tiveram seus condutos radiculares preenchidos com guta-percha, pela técnica da condensação lateral. Vinte e nove desses não utilizavam pinos intra-radiculares e tiveram suas câmaras pulpares até $2 \mathrm{~mm}$ abaixo da junção cemento-esmalte preenchida com cimento de silicato. O restante dos dentes recebeu pinos intra-radiculares com remoção do material restaurador intracanal até $8 \mathrm{~mm}$. Pinos intraradiculares Kerr Endo-post fram cimentados com cimento de Fosfato de Zinco. Os dentes foram colocados em cilindros de alumínio preenchidos com resina acrílica, montados em um ângulo de $130^{\circ}$ em relação ao longo eixo do dente, e em seguida, receberam uma força de compressão através da máquina de teste Istron. O resultado encontrado mostrou que não houve 
diferença estatística significativa quando da utilização ou não de pinos intraradiculares.

MONDELLI et al. ${ }^{96}$, em 1980, estudaram a resistência à fratura de pré-molares, onde variavam a amplitude vestíbulo lingual de 3 tipos de preparo: oclusais, próximo oclusais com duas faces e preparos MOD. Para realizar a pesquisa, utilizaram 100 pré-molares recém extraídos de pacientes com idade entre 20 e 25 anos. Foram divididos 30 dentes para cada tipo de cavidade, onde 3 diferentes diâmetros de preparo eram confeccionados para cada grupo de 10 dentes. O grupo controle foi composto por 10 dentes hígidos. Após a divisão e realização dos preparos, foram incluídos em blocos de resina e submetidos à fratura, sob carregamento de compressão, a uma velocidade de $0,5 \mathrm{~mm}$ por minuto. Uma esfera com $4 \mathrm{~mm}$ de diâmetro contatava ambas as cúspides dos pré-molares, simulando uma carga oclusal. Concluíram que todas as cavidades são capazes de diminuir a resistência dos dentes e que a amplitude da cavidade está diretamente relacionada à resistência à fratura do remanescente dental.

CHRISTIAN et al. $^{28}$ em 1981 , selecionaram 25 molares inferiores intactos recém-extraídos, cortaram a coroa $2 \mathrm{~mm}$ acima da junção amelocementária e montaram em um cilindro de resina acrílica. Os dentes foram divididos em 3 grupos: A) dentes íntegros; B) núcleos de amálgama sem pinos e C) núcleos de amálgama com pinos intra-radiculares. Os dentes foram montados em uma máquina INSTRON com uma angulação de incidência de força de $90^{\circ}$. Ao final dos testes os autores encontraram que 
os dentes hígidos foram os mais resistentes (269 libras) seguidos pelos núcleos de amálgama com pinos intra-radiculares (142 libras) e os núcleos de amálgama sem pinos intra-radiculares.

Salientando que a principal função de um pino é proteger um dente enfraquecido contra fratura CHAN e BRYANT ${ }^{24}$, em 1982, publicaram uma investigação científica com o intuito de comparar a resistência à fratura e as características de falha de dentes posteriores tratados endodonticamente. Os materiais usados foram ouro fundido, amálgama com pino e resina composta com pinos. Os pinos foram colocados em 55 pré-molares inferiores á uma profundidade de 8 milímetros e 0,06 polegadas de largura. Vinte e quatro horas depois de confeccionados os núcleos, os dentes foram preparados e moldados para confecção de uma coroa total fundida. Os dentes foram montados em cilindros de acrílico e colocados em uma máquina de ensaios para medir a resistência ao cisalhamento. Após realizados os testes encontrourse que os núcleos em ouro fundido necessitaram de menos força para falharem. Todos os núcleos fundidos apresentaram deslocamento e a maioria deles apresentou fratura da raiz. Espécimes de amálgama e resina relataram fratura do núcleo mas apresentaram menor evidência de deslocamento do núcleo sendo que os núcleos de resina composta não relataram fratura da raiz tão freqüentes como núcleos de amálgama. Os autores concluíram que os núcleos de preenchimento de resina composta e amálgama são alternativas altamente aceitáveis e a superioridade destas, se deve provavelmente à rigidez dos 
postes de aço e a adaptação superior do amálgama e resina composta em relação aos núcleos fundidos.

HOAG e DWYER ${ }^{59}$, em 1982, avaliaram três formas de reconstrução de dentes posteriores: ouro fundido, amálgama e resina composta avaliando também, o efeito da coroa total metálica nestes três tipos de núcleos. Os autores selecionaram 40 molares inferiores e os dividiram em 3 grupos: A) núcleo fundido em ouro; B) núcleo de resina composta com pino intraradicular e C) núcleo de amálgama condensado $4 \mathrm{~mm}$ dentro dos canais. Metade dos dentes receberam uma coroa total e a outra não. Com o intuito de simular as forças de mastigação os dentes foram montados em ângulo de 45 em uma máquina de testes. Nos grupos sem coroa total os núcleos fundidos foram bem superiores aos núcleos de preenchimento, sendo que amálgama e resina composta apresentaram o mesmo resultado. Os grupos com coroas foram bem mais resistentes que os dentes sem coroa. Nos grupos com coroa total não houve diferença entre os tipos de núcleos. Como conclusão os autores indicaram que o método de núcleo pode não ser significante se a coroa fundida tiver suas margens integralmente além do núcleo.

Em 1982, comparando pinos pré-fabricados e núcleos metálicos fundidos, MILLER ${ }^{94}$ chegou as seguintes conclusões: os pinos e núcleos pré-fabricados podem simplificar e acelerar o procedimento restaurador em dentes despolpados; os pinos rosqueáveis têm maior retenção, mas apresentam um risco maior de fratura; os pinos cilíndricos sem roscas 
são mais retentivos que os cônicos, mas podem ter maiores chances de perfuração radicular; os sistemas que possuem brocas de tamanho padronizado para preparação do conduto podem causar danos à raiz quando usados indevidamente.

A fim de conhecer as possíveis conseqüências da presença de um pino intra-radicular em dentes tratados endodonticamente, MATTISON ${ }^{89}$, em 1982, realizou um estudo através de análise fotoelástica. Esta análise serviu para comparar fotograficamente o estresse gerado após a sobrecarga de pinos fundidos em ouro com 2 diâmetros diferentes e núcleo de resina composta. Três principais conclusões foram obtidas: o diâmetro do pino reconstruído com resina composta altera a magnitude do estresse; estresses geralmente aumentam quando o diâmetro do pino aumenta; o estresse aumenta quando as cargas verticais aumentam. Aconselhou a diminuição diâmetro do pino usado, particularmente quando grandes forças oclusais são exercidas pelo paciente. $\mathrm{O}$ uso de pinos de diâmetros menores reduz 0 estresse exercido sobre a dentina e estruturas de suporte e limita a quantia de material dentário removido durante o preparo.

STACKHOUSE ${ }^{143}$, em 1982, recomendam a utilização de pinos fundidos no interior do conduto tratado endodonticamente, como método de reforço. O autor recomenda o uso desta técnica em casos de reforço de coroas artificiais individuais, reforço de dentes incluindo grandes esplintagens, substituição de coroa que tenha fraturado na raiz e substituição de próteses fixas que tenham soltado. 
No ano de 1983, DEUTSCH, et al. ${ }^{37}$, publicaram uma revisão da literatura avaliando os núcleos intra-radiculares pré-fabricados disponíveis no início daquela década. Os estudos demonstram que os núcleos intraradiculares apresentam duas principais funções: primeira a de reforçar a porção coronária e a porção radicular do dente contra fratura, no caso de existência suficiente de estrutura coronária e a segunda, é que na falta de uma quantidade considerável da estrutura coronária, o núcleo é utilizado para repor esta falta, além de reter e suportar a restauração protética subseqüente.

BENDER e FREEDLAND ${ }^{14}$, em 1983, discorreram sobre a ocorrência de fratura radicular causada por oclusão traumática, procedimentos iatrogênicos e causas patológicas. Nove casos clínicos foram acompanhados e o tipo mais comum de fratura vertical da raiz foi causado após processos iatrogênicos, devido aos tratamentos que utilizam instrumentos que causam a remoção excessiva de estrutura dental para o acesso endodôntico e também o alargamento excessivo do canal, ocasionando o enfraquecimento da raiz.

PETERS et al. ${ }^{107}$, em 1983, através da análise de elementos finitos, analisaram as tensões geradas por pinos intra-radiculares de comprimento, forma e diâmetros diferentes em dentes tratados endodonticamente restaurados com coroa protética. Avaliaram também o efeito da espessura da camada e tipo de cimento. Concluíram que: os pinos com diâmetro menor concentram maior esforço sobre as paredes do canal radicular; quanto à 
forma, descobriram que, independente da forma, as tensões concentram-se principalmente nas suas terminações apicais e maior intensidade em pinos cônicos; com relação aos tamanhos, que pinos cilíndricos longos são os mais aconselhados, devendo-se respeitar os limites da raiz.

Por meio de ampla revisão de literatura sobre o uso de pinos, GREENFELD; MARSHALL ${ }^{48}$, em 1983, ditaram algumas normas para o seu sucesso: 1) os pinos para promoverem uma resistência adequada, têm que ter sobre si uma coroa satisfatória; 2) só devem ser usados quando perfeitamente indicados e devem ter retenção suficiente para manter uma coroa; 3) devem ser colocados somente na presença de tratamentos endodônticos perfeitos; 4) pinos cilíndricos distribuem melhor as forças; 5) não se deve usar pinos que requeiram grande remoção de estrutura dentinária; 6) devem ser evitadas ligas que possam se distorcer; 7) deve-se usar para os pinos a mesma liga que será usada nas coroas, para se evitar corrosão; 8) em toda a volta do pino deve-se ter $1 \mathrm{~mm}$ de dentina sadia; 9 ) dentes com raízes curtas devem ter pinos cimentados com ranhuras adicionais; 10) uma retenção ótima é conseguida com pinos de 7 a $11 \mathrm{~mm}$ de comprimento; 11) todos os agentes cimentantes, quando usados de acordo com as especificações dos fabricantes, permitem ótimos resultados de retenção; 12) o uso de pinos em dentes tratados endodonticamente não predispõe ao sucesso, podendo ocorrer fraturas. A partir destas conclusões, admitiram que o pino ideal deveria ter as seguintes características: ser cilíndrico, com 9 a $11 \mathrm{~mm}$ de comprimento a partir da junção cemento/esmalte, ou longo o bastante para abranger metade do suporte ósseo da raiz; serrilhado para proporcionar boa retenção; ser 
resistente à fratura durante a manipulação e função; ser de fácil instalação; passível de remoção e custo relativamente barato.

SORENSEN e MARTINOFF ${ }^{135}$, em 1984, fizeram um estudo correlacionando a parte clínica e laboratorial de 1273 dentes tratados endodonticamente para determinar a importância clínica de reforço do pino e da cobertura coronal bem como a importância da localização do dente no arco durante o planejamento. Os autores concluíram que não existiu aumento significante na resistência à fratura ou ao deslocamento obtido com reforço intracoronal para os 6 grupos anatômicos de dente; a cobertura coronal não aumentou significativamente a taxa de sucesso clínico de dentes anteriores superiores e inferiores e que a taxa de sucesso clínico foi significativamente aumentada com cobertura coronal nos pré-molares e molares superiores e inferiores. Eles sugerem que o recobrimento da estrutura dentária seria mais eficiente no reforço do elemento dentário do que a fabricação de um núcleo para tais dentes. No caso de uma real necessidade de núcleos intra-radiculares o comprimento, forma, tipo de superfície e diâmetro devem ser observados atentamente. Não foi encontrada diferença estatisticamente significativa quando comparadas as porcentagens de sucesso dos dentes anteriores superiores restaurados com ou sem pinos intra-radiculares. Os autores salientam ainda que pinos intraradiculares não devem ser indicados com o propósito de reforçar a estrutura remanescente, pois, o espaço para o pino pode levar à remoção excessiva de estrutura dentária. 
Os mesmos autores ${ }^{136}$, no mesmo ano, correlacionaram os 1273 casos de dentes tratados endodonticamente para investigar o significado de determinados fatores como desenho, comprimento, configuração da superfície, diâmetro na confecção de núcleos intra-radiculares e suas sobrevidas. As variáveis avaliadas foram: 1) método de reforço intracoronário nas categorias (a) núcleos metálicos fundidos (b) Parapost e núcleo de preenchimento de amálgama ou resina composta (c) núcleos metálicos fundidos de Parapost (d) pinos rosqueados (e) Amalgamapin (f) pino dentinário com resina composta; 2) tamanho do núcleo intra-radicular determinado através de radiografia; 3) modo de falha, dividido em dois grupos, os restauráveis por falha de deslocamento e os não restauráveis por falhas originadas de fraturas obliquas e horizontais, fratura vertical do dente e perfuração iatrogênica do dente. Ao final do estudo foi concluído que pinos serrilhados cilíndricos fundidos com porção coronária e pinos serrilhados cilíndricos com porção coronária em amálgama ou resina composta, registraram os resultados mais satisfatórios; pinos cônicos fundidos com porção coronária, apresentaram maior risco de falha do que os de dentes tratados sem reforço intracoronário; pinos serrilhados não apresentaram falhas causadas por fratura dental; dentes com comprimento de pino igual ou maior que o tamanho da coroa, apresentaram percentual de sucesso superior a noventa e sete por cento.

Em um estudo realizado por LINDHE $^{80}$, em 1984, foram avaliados 51 dentes restaurados com pinos pré-fabricados e núcleos de preenchimento em resina composta após 10 anos, onde foram encontrados 43 destes 
funcionando satisfatoriamente e um onde a coroa foi perdida de seu núcleo. A falha dos outros sete dentes foi por fratura radicular, cárie secundária e/ou retenção do pino inadequada.

Com o objetivo de comparar a resistência á compressão de dentes posteriores endodonticamente tratados com diferentes formas de núcleos GELFAND et al. ${ }^{47}$, em 1984, selecionaram 156 dentes molares superiores e inferiores divididos em 6 grupos: 1) núcleo de amálgama com 2 pinos Parapost; 2) núcleo de resina composta com 2 pinos Para-post; 3) núcleo de amálgama com o mesmo condensado dentro de 3 canais; 4) núcleo de resina composta condensada dentro de 3 canais; 5) núcleo fundido com pino em um canal e 6) dente natural com Cavit dentro da câmara pulpar. Destes 156 dentes, metade recebeu uma coroa total fundida e a outra metade não. Os dentes foram montados em blocos de resina acrílica e colocados sob uma angulação de $45^{\circ}$ em uma máquina de testes Instron. Após os testes os autores concluíram que quando se coloca uma coroa total não há diferença nos resultados de resistência á compressão. Nos dentes sem coroas os núcleos de amálgama e resina composta condensados $3 \mathrm{~mm}$ dentro dos canais foram mais resistentes do que os mesmos com pinos Para-post $7 \mathrm{~mm}$ dentro dos canais. Os núcleos fundidos foram os mais resistentes nos grupos que não receberam coroa total.

TJAN e WANG ${ }^{151}$ em 1985, avaliaram a resistência de raízes com condutos preparados com tamanhos proporcionais às várias espessuras de dentina, os fatores biomecânicos que afetam a capacidade de proteção da 
estrutura dentinária remanescente e o poder de retenção da restauração. O comprimento, diâmetro, configuração, saliências na superfície e o material utilizado podem afetar a resistência e retenção de um núcleo. Além destas variáveis, a espessura do cimento foi avaliada. Os autores concluíram que núcleos com paredes paralelas seriam mais retentivos do que os núcleos cônicos. Quanto mais longo e largo é o núcleo, maior é a sua resistência e retenção, mas, o alargamento excessivo do conduto pode enfraquecer a raiz por perda de dentina e causar fratura radicular. Com relação à espessura dentinária foram experimentadas as de $1 \mathrm{~mm}, 2 \mathrm{~mm}, 3 \mathrm{~mm}$ e $1 \mathrm{~mm}$ com término œrvical em bisel de $60^{\circ}$. O resultado mostrou que as raízes com $1 \mathrm{~mm}$ de espessura na parede vestibular são mais propensas à fratura.

Em 1985, IRVIN et al. $^{64}$, avaliaram, através de uma análise fotoelástica, o padrão de estresse induzido pela inserção de pinos retentivos auto-rosqueáveis e observaram que o desrosqueamento de 1/4 até meia volta, resulta numa significativa diminuição do estresse gerado. Foi notada também uma zona de grande estresse quando estes pinos foram inseridos completamente no canal preparado, levando a uma correlação com a presença de trincas ou fendas na estrutura dentária.

A análise da relação entre o tamanho da raiz, tamanho do núcleo e a possibilidade de fratura radicular durante a inserção de núcleos préfabricados, foi analisada por DEUTSCH et al. ${ }^{38}$, no ano de 1985. Foram utilizados três sistemas diferentes de pinos pré-fabricados em 212 dentes, considerando-se a morfologia radicular, comprimento, diâmetro, forma, tipo 
de rosqueamento, forma do pino, distribuição da dentina remanescente e quantidade de força durante a inserção, concluíram que núcleos préfabricados, rosqueados e cônicos apresentam maior incidência de fratura, e que dentes menores apresentam mais complicações durante a inserção do núcleo.

Questionando se um pino intra-radicular realmente reforça um dente tratado endodonticamente TROPE et al. ${ }^{154}$, em 1985, compararam a resistência à fratura de incisivos centrais superiores tratados endodonticamente sob diferentes métodos de restauração. Os 64 dentes foram divididos em 8 grupos: 1) câmara pulpar preenchida com resina composta; 2) câmara pulpar condicionada com ácido e preenchidos com resina composta; 4) conduto preparado $10 \mathrm{~mm}$ e deixado vazio; 5) câmara pulpar e $10 \mathrm{~mm}$ dentro do canal apenas preenchido com resina composta; 6) Pino Para-post cimentado no canal e câmara pulpar preenchida com resina composta; 7) Pino Para-post cimentado com fosfato de zinco no canal, câmara pulpar condicionada com ácido e preenchida com resina composta; 8) Canal radicular e câmara pulpar condicionados com ácido, pino Para-post cimentado com resina composta. Os dentes foram montados em um ângulo de $50^{\circ}$ e a resistência à fratura foi medida em uma máquina Instron. Como resultado os autores não encontraram nenhuma melhoria na resistência dos dentes após o condicionamento ácido da dentina. O preparo do conduto para um poste diminuiu significativamente a resistência do dente. A cimentação de um pino intra-radicular enfraqueceu o dente tratado endodonticamente. 
PLASMANS et al $^{111}$., em 1986, compararam a resistência de núcleos metálicos fundidos, amálgama com pino Unimetric, amálgama sem pino e Amalgama pin sob forças oblíquas. Os núcleos foram confeccionados em dentes naturais montados em um plano inclinado de $45^{\circ}$ com o intuito de simular forças de compressão ou cisalhamento exercidas por um dente antagonista. Após os testes os autores concluíram que apesar da resistência superior dos núcleos fundidos, os núcleos de amálgama apresentam um comportamento satisfatório em casos onde o dente não está sujeito às forças além do normal, como retentor de prótese fixa ou pacientes com bruxismo. Os autores concluíram também que a colocação de um pino intraradicular em núcleos em amálgama não aumentou a resistência dos dentes despolpados.

KAYSER et al. ${ }^{72}$, em 1987, traçaram uma comparação entre núcleos metálicos fundidos e núcleos de resina composta com pinos intraradiculares. Os autores afirmaram que em torno de $50 \%$ dos dentes que irão receber uma restauração metálica fundida ou uma coroa de jaqueta necessitam de um núcleo. Para eles os núcleos fundidos apresentam alguns problemas como necessidade de remoção exagerada de estrutura dental sadia, alto custo e retenção insuficiente em alguns casos. Ao final do artigo os autores descrevem uma técnica de confecção de núcleos de preenchimento em molares utilizando resina composta e pinos intraradiculares. Os autores fizeram um acompanhamento clínico desta técnica durante 13 anos relatando excelentes resultados, mas indicam este tipo de núcleos apenas para restaurações unitárias. 
PAO et al. ${ }^{103}$, em 1987, utilizaram um modelo matemático produzido por computador para analisar o efeito do pino de extremidade cônica sobre o estresse transmitido para a dentina, em dentes com suporte periodontal reduzido. Em dentes com suporte ósseo normal, que requerem pinos, longos e de grande diâmetro, os pinos com extremidade cônica produziram níveis máximos de força, em dentina, enquanto reduziam o risco de perfuração do conduto durante o preparo. Nos dentes com suporte periodontal reduzido, os pinos com extremidade cônica, reduziram também as forças transmitidas à dentina, quando comparados aos cilíndricos. Outro fator a ser considerado no uso de pinos cônicos é a preservação de maior quantidade de dentina na região do ápice do pino.

LEARY; AQUILINO e SVARE ${ }^{78}$, em 1987, avaliaram o comprimento do pino dentro dos limites elásticos da dentina. Foram utilizadas amostras preparadas com variados tamanhos de diâmetro dos canais e diferentes comprimentos de inserção dos pinos nos canais radiculares. Os resultados mostraram que quando a estrutura dentária interna é removida, o dente fica enfraquecido, que a cimentação de pinos intra-radiculares pré-fabricados recupera apenas parte desta resistência perdida, e que com pinos cimentados parece existir alguma trans ferência de carga.

STOKES $^{148}$, em 1987, realizou uma revisão de literatura a respeito de pinos e seus princípios mecânicos e biológicos. Concluiu que o dente que passa por uma intervenção endodôntica com mínima perda dentinária, não é mais susceptível á fratura do que um dente vitalizado. Entre muitos sistemas 
de pinos avaliados, os pinos cilíndricos cimentados apresentaram o maior índice de sucesso. Pinos cilíndricos rosqueáveis, utilizados em combinação com reconstruções coronárias diretas em resina composta, oferecem uma técnica rápida, mas não devem ser aconselhados enquanto não existirem mais estudos clínicos descritos.

BRANDAL et al. ${ }^{18}$, em 1987, compararam e resistência à fratura de dentes anteriores restaurados através de pinos pré-fabricados e núcleos em resina composta, amálgama e ionômero de vidro. Para isto, quarenta e cinco raízes receberam tratamento endodôntico e foram divididas em três grupos: 01 - pinos intra-dentinários e núcleo em amálgama; 02 - pino intra-radicular e núcleo em resina composta; 03 - núcleo em ionômero de vidro sem quaisquer pinos. Todos os dentes foram preparados para receber coroa protética, sendo que o término do tipo ombro em ângulo vivo envolvia $1 \mathrm{~mm}$ de estrutura dentinária. O carregamento foi aplicado num ângulo de $135^{\circ}$ em relação ao longo eixo do dente, a uma velocidade de $5 \mathrm{~cm} / \mathrm{min}$. Os resultados demonstraram haver diferença estatística entre os três grupos, sendo que a maior média de resistência à fratura foi a do grupo restaurado com pinos intra-radiculares e núcleo em compósito, seguido pelo grupo dos pinos intradentinários e núcleo em amálgama e pelo grupo restaurado através de ionômero de vidro convencional. Os valores do grupo restaurado com o ionômero de vidro apresentaram resultados inferiores aos da carga mastigatória dos anteriores (16 kg), por isso os autores contra-indicam a sua utilização clinica. Comparam os resultados aos de estudos prévios, em que utilizaram a mesma metodologia para confecção de núcleos metálicos fundidos, apre- 
sentando resultados inferiores aos do grupo restaurado com compósito. Atribuem a superioridade do grupo 2 a forma geométrica dos pinos préfabricados que, por serem paralelos, evitam o seu desalojamento. Discutem vantagens dos núcleos em resina composta que, além da superior resistência, permitem uma maior preservação de estrutura dental sadia.

TALEGHANI e MORGAN ${ }^{149}$, em 1987, avaliaram a utilização de amálgama, resina composta e ionômero de vidro na reconstrução de dentes tratados endodonticamente. Sobre o amálgama, fizeram as seguintes ponderações: (A) é o material mais utilizado, $(B)$ reduz o tempo de uso e do custo, sem a necessidade de equipamento especial, (C) tem boa resistência às forças horizontais e verticais e é um bom suporte para restaurações fundidas, (D) como desvantagem apresenta expansão térmica duas vezes a do dente. Salientaram ainda a utilização do verniz copal para prevenir microinfiltração inicial. Sobre a resina composta: (1) fácil manipulação, (2) rápido tempo de polimerização, (3) baixa contração de polimerização (4) dispensa equipamento especial, porém apresenta a desvantagem de ter uma expansão térmica três vezes maior que a do dente, aumentando assim a microinfiltração e permitindo o aparecimento de cárie recorrente. Ionômero de vidro de presa rápida com partículas de prata (ketac Silver): (A) se une quimicamente á estrutura dentária, (B) libera flúor á estrutura dental adjacente, (C) fácil inserção, (D) preparação imediata do dente, (E) coeficiente de expansão térmica similar ao da estrutura dentária: e portanto, concluiu que este é um material superior ao amálgama e a resina composta. 
Afirmando que muita ênfase tem sido dada pela literatura aos pinos pré-fabricados e pouco se têm estudado sobre os materiais usados na construção de núcleos, TALEGHANI e LEINFELDER ${ }^{150}$, em 1988, fizeram uma investigação científica para determinar comparativamente se núcleos de ionômero de vidro reforçado com prata com e sem pinos intra-radiculares e núcleos fundidos tem a capacidade de melhorar a resistência à fratura de pré-molares superiores, sob oclusão simulada. Sobre os núcleos foram confeccionadas coroas totais fundidas e, em seguida, realizados os testes de resistência em uma máquina Instron. Os resultados mostraram que os núcleos de ionômero de vidro com pinos intra-radiculares ofereceram a mesma resistência à fratura aos dentes do que os núcleos metálicos fundidos e que os núcleos de ionômero sem pinos não foram efetivos em dentes com grande perda coronária.

PLASMANS et $\mathbf{a l}^{112}$, em 1988, publicaram um estudo onde avaliaram a resistência à fratura de núcleos de resina composta com e sem pinos intraradiculares. Os autores selecionaram 20 molares inferiores recém extraídos que tiveram as suas coroas cortadas $2 \mathrm{~mm}$ acima da junção cemento esmalte. Os dentes foram divididos em quatro grupos experimentais e um controle: A) resina composta auto-polimerizável e pino Unimetric: b) resina composta auto-polimerizável sem pino; C) resina composta autopolimerizável na câmara pulpar, resina fotopolimerizável no restante da coroa e pino Unimetric; D) resina composta auto-polimerizável, resina fotopolimerizável no restante da coroa sem pino e grupo E) (controle): núcleo metálico fundido. Os dentes foram montados em cilindros de resina acrílica e 
montados em um ângulo de $45^{\circ}$ para teste em uma máquina Instron. Os autores concluíram após os testes que os núcleos de resina composta são bastante satisfatórios e a presença de um pino intra-radicular não trouxe nenhum benefício à resistência do dente podendo levar este a uma fratura na porção radicular não passível de reparo. O autor afirma que um pino metálico pode ser necessário se a câmara pulpar e o remanescente dentário não puderem propiciar retenção e resistência suficiente ao núcleo.

BARABAN $^{11}$, em 1988, disse que a escolha do método para restaurar dentes tratados endodonticamente dependia de estrutura coronária remanescente; quando grande parte desta estivesse presente, um método mais conservador poderia ser utilizado, mas quando houvesse grandes destruições, a porção coronária deveria ser reconstruída por ouro, amálgama, resina composta ou cimento de ionômero de vidro; porém, existiam algumas situações onde os pinos intra-canal deviam ser contra-indicados: (1) quando o dente possuir raízes muito encurvadas, (2) quando houver presença de cone de prata que não foi removido na profundidade adequada e (3) quando um pino que foi colocado anteriormente não puder ser removido. Um dente com uma fratura abaixo da crista óssea, e dentes com cáries extensas na porção cervical da raiz também há impossibilidade na restauração dos mesmos. Os pinos intracanal promovem suporte para o núcleo de preenchimento, também reforçam contra possíveis fraturas das raízes. Para estas finalidades, indicou o uso do sistema Parapost fazendo apenas duas restrições: (A) comprimento do canal radicular pequeno para promover a retenção desejada, (8) porção cervical do canal muito larga, nestes casos poderão ser usa- 
dos os pinos rosqueados (Dentatus) devido à sua variedade de comprimento e largura. O pino intracanal deverá ter um comprimento igual á metade do comprimento da raiz suportada por osso. Deve permanecer 3,4 ou $5 \mathrm{~mm}$ de guta-percha como selamento apical. Pressão exagerada durante o assentamento dos pinos ou núcleos pode induzir a fraturas. O ionômero de vidro utilizado como material de preenchimento forma uma união química com a dentina prevenindo micro-infiltrações, libera flúor inibindo a formação de cárie na estrutura dentária adjacente.

RADKE; BARKORDAR e PODESTA ${ }^{113}$, em 1988, compararam o valor retentivo de três cimentos (fosfato de zinco, ionômero de vidro e policarboxilato) e um cimento resinoso, utilizados para cimentação de pinos Para-post em dentes unirradiculares. A análise dos resultados mostrou que o fosfato de zinco e o ionômero de vidro foram os mais retentivos, seguidos pelo cimento de policarboxilato e cimento resinoso.

Em 1988, SORENSEN ${ }^{137}$, publicou um artigo procurando apresentar diretrizes de procedimentos para restauração de dentes tratados endodonticamente, levando em consideração a quantidade de estrutura dentária remanescente, posição do arco e os tipos de pilares que estes dentes seriam. Salienta que o clínico deve ser flexível, realizando o tratamento segundo as necessidades de cada paciente. A conclusão do autor é que cada situação exige técnicas e/ou materiais diferentes. O objetivo principal é restaurar o dente tratado endodonticamente 
restabelecendo a função com previsibilidade e longevidade, além de um tempo adequando e custos razoáveis para o paciente.

ASSIF et al. $^{4}$, em 1989, utilizaram um modelo fotoelástico com o intuito de examinar a influência de diferentes tipos de restaurações colocadas após terapia endodôntica, enfatizando a maneira com que as forças aplicadas à superfície oclusal fram dispersas para as estruturas de suporte dos dentes tratados. Os autores selecionaram pré-molares intactos divididos em 4 grupos: A) Dente intacto após obturação do canal; B) Dente após tratamento endodôntico coberto com uma coroa total; C) Dente com pino e núcleo de resina composta e D) Dente com núcleo fundido e œroa total. Os dentes foram montados em um material foto-elástico e fotografados no campo de luz polarizada. Ao final do estudo os autores enfatizam que talvez um pino metálico não atenda todas as recessidades de um dente tratado endodonticamente pois é feito de um metal rígido com um módulo de elasticidade muito maior do que a estrutura dental e tem o potencial de fraturar a raiz. Para os autores o dente deve ser restaurado com um material que possua módulo de elasticidade semelhante ao da dentina o que pode ser melhor obtido pelas resinas compostas que também possuem alta resistência ao cisalhamento.

No ano de 1989, BERGMAN et al. ${ }^{15}$, analisaram, numa situação "in vivo", dentes tratados endodonticamente restaurados através de núcleo metálico fundido. Foram analisados noventa e seis casos, entre homens e mulheres. Destes núcleos fundidos, quarenta e nove foram colocados em 
coroas individuais e quarenta e sete instalados em dentes suportes de próteses parciais fixas. Os autores concluíram que núcleos metálicos fundidos podem ser ecomendados tanto num caso como no outro como meio de retenção para restaurações indiretas. As falhas ocorridas no tratamento endodôntico não tiveram nenhuma correlação com o tratamento protético utilizado.

HUNTER et al. ${ }^{63}$, em 1989, estudaram os efeitos do tratamento endodôntico, preparo do canal para receber pino pré-fabricado e sua cimentação em raízes de incisivos centrais, através da análise fotoelástica. Os resultados demonstraram que a remoção de estrutura dentinária do canal radicular aumenta a concentração de esforços nas suas paredes e, portando, a tendência à fratura. Pinos com diâmetro mais largo se adaptam melhor ao longo do canal radicular, entretanto, o diâmetro maior em pinos curtos aumenta a concentração de tensão na região apical. Para os autores a cimentação dos pinos intra-radiculares em dentes com o canal tratado, torna-se desnecessária, mas no caso de canais muito alargados isto reforçaria os dentes.

BARKHORDAR et al. ${ }^{13}$, no ano de 1989 , tentaram provar a eficiência de um colar metálico na resistência de dentes tratados endodonticamente para fraturas radiculares. Foram selecionados 20 incisivos centrais superiores sem cáries ou fraturas e separados em dois grupos de 10 dentes. No grupo I foram colocados pinos intra-radiculares de $8 \mathrm{~mm}$ sem colar metálico, e o grupo II teve pinos intra-radiculares de $8 \mathrm{~mm}$ e um colar ao 
redor da porção cervical de $2 \mathrm{~mm}$ de comprimento, com $3^{0}$ de angulação de cada lado das paredes dentinárias coronárias, totalizando 6을 de convergência. A espessura para as paredes de dentina era de $1 \mathrm{~mm}$ pra os dois grupos, e no segundo grupo foi confeccionado, por cima da parede, um colar metálico de $2 \mathrm{~mm}$. Os pinos foram fundidos em liga de ouro e cimentados com cimento de fosfato de zinco. As forças oblíquas durante o teste de compressão foram aplicadas pela face palatina e velocidade de $5 \mathrm{~cm} / \mathrm{min}$ em um ângulo de $135^{\circ}$ de inclinação em relação ao plano horizontal. Houve uma diferença estatisticamente significativa na localização da fratura entre os dois grupos. Do total, 5 espécimes do grupo I, sem 0 colar metálico, fraturaram longitudinalmente; 4 falharam obliquamente, se estendendo da junção cemento - esmalte para o terço apical, e o 1 teve fratura horizontal. A média de carga de falha foi de 49,6kg. No grupo II, nove espécimes fraturaram, e um foi descartado por fratura da base de resina; 4 tiveram fratura no terço apical, 1 exibiu fratura horizontal e vertical, 2 separados com linha de fratura mais apical na superfície lingual e 1 teve fratura oblíqua. A média de fratura foi de $65,29 \mathrm{Kg}$. Os autores concluíram que o grupo com colar metálico demonstrou uma média de resistência superior. Isto tem importância principalmente na utilização do œlar metálico como suporte para próteses fixas ou removíveis.

Em 1990, ROBBINS ${ }^{117}$, em revisão de literatura, salientou sobre alguns parâmetros que norteiam a restauração de dentes tratados endodonticamente. Ele comenta que deve-se ter muito cuidado com a máxima preservação da estrutura dentinária, tanto no tratamento 
endodôntico quanto na confecção do núcleo, possibilitando assim o sucesso do tratamento, pois, desta maneira evitaria o enfraquecimento da raiz. $O$ diâmetro do núcleo deve ser o menor possível. O maior comprimento do núcleo aumenta a retenção e a resistência. Núcleos rosqueáveis são mais retentivos do que aqueles que apresentam paredes paralelas.

LONEY, KOTOWIEZ e McDOWEL ${ }^{82}$, em 1990, avaliaram o efeito de abraçamento de uma férula de $1,5 \mathrm{~mm}$ de altura através de análise de estresse por fotoelásticidade em modelos tridimensionais. $O$ efeito de abraçamento neste estudo foi desenvolvido pelo envolvimento da dentina pelo próprio núcleo metálico. Foi notada diferença estatística entre as amostras com e sem férula em relação a distribuição de tensões. A amostra sem colar metálico demonstrou menor concentração de tensões na região gengival e na parede lingual da raiz, enquanto que, nas demais regiões não houve diferença estatística entre os grupos. Aplicando a força pela face lingual do núcleo, foi registrada uma maior concentração de tensão na parede lingual da raiz junto ao ápice para ambas amostras. Embora a férula não tenha contribuído para diminuição das tensões sobre a raiz, a distribuição geral das forças foi mais equilibrada do que no grupo sem férula. Os autores sugerem que o colar metálico poderia unificar as estruturas remanescentes.

SORENSEN e ENGELMAN ${ }^{139}$, em 1990, pesquisaram a influência da adaptação de um pino intra-radicular na resistência de dentes tratados endodonticamente. Foram utilizados 40 incisivos centrais superiores 
divididos em quatro grupos. Nos grupos 1, 2 e 3 somente $1 \mathrm{~mm}$ de estrutura axial radicular foi deixada, ao nível do ombro, criando um largo canal com forma afunilada. A profundidade de preparo do conduto foi igual para todos os grupos e a altura da porção coronária do núcleo metálico fundido foi de 7mm. Um pino intra-radicular de plástico Para-post foi adaptado e posteriormente foi fundido, tornando-se um núcleo metálico fundido. O grupo 1 consistiu de um pino intra-radicular Parapost, sem se estender dentro do canal. Portanto, parte do canal foi preenchido com cimento, deixando o pino intra-radicular sem contato direto com as paredes radiculares; no grupo 2 foram usados pinos intra-radiculares com metal intimamente adaptados as paredes do canal, com espessura mínima de cimento; no grupo 3 foram usados pinos intra-radiculares para-post que preencheram o canal, totalmente adaptados. O processo de ceroplastia das coroas foi feito diretamente nos dentes, as quais foram fundidas em metal básico. Posteriormente, foram cimentadas com dimento de fosfato de zinco. Um dispositivo foi feito nas coroas para permitir uma carga num ângulo de $130^{\circ}$ em relação ao longo eixo do dente. A carga foi feita a uma velocidade de 2,54mm por min. As falhas ocorridas foram devido ao deslocamento da coroa, deslocamento do pino intra-radicular, fratura da raiz, ou fratura do pino intra-radicular. A média de valores de carga até a falha foi de: Grupo 1: 22,4kg $\pm 4,4$; Grupo 2: 49,58Kg $\pm 10,26$; Grupo 3: 29,47kg $\pm 5,89$; Grupo 4: $28,89 \mathrm{Kg} \pm 9,47$. Uma análise do modo de fratura demonstrou que 17 dos 20 dentes nos grupos 2 e 3 falharam devido à fratura. Esse alto índice de fratura ocorreu em pinos intra-radiculares que se adaptaram intimamente 
com a configuração radicular. Nas amostras em que somente o Parapost se estendeu dentro do canal (grupo 1 e 4), falhas ocorreram devido à fratura do dente e falha do cimento. Em todas as 6 amostras do grupo 1, com falha de cimento, ocorreram o entortamento dos pinos intra-radiculares. Vistos de um aspecto proximal, os grupos 2 e 3 tiveram uma incidência de fratura mais alta quando comparados com o grupo 4. As fraturas do grupo 2 e 3, em que foram usados pinos intra-radiculares cônicos, envolveram mais estrutura dentária do que os pinos paralelos. Esse estudo questiona a remoção adicional de estrutura dentária para acomodar pinos intra-radiculares de paredes paralelas. O grupo 1, com somente $1 / 3$ dos pinos intra-radiculares em contato íntimo com os remanescentes radiculares em contato, teve uma média de limiar de falha igual aquela do grupo 4 , onde os pinos intraradiculares eram paralelos, intimamente adaptados às paredes do canal. Ainda, uma grande quantidade de cimento circundando os $2 / 3$ incisais dos pinos intra-radiculares não afetou o limiar de carga para falha.

Os mesmos autores ${ }^{138}$, em 1990 , estudaram a resistência à fratura de dentes com diferentes tipos de término gengival para obter o efeito de abraçamento através da férula. Definem a férula como uma banda circunferencial metálica ao redor da margem gengival do preparo do dente, que tem por objetivo melhorar a resistência dental contra as forças de alavanca, contra o efeito de cunha dos pinos cônicos e contra as tensões geradas durante a inserção do pino. Sessenta incisivos centrais tiveram suas coroas removidas, permanecendo $15 \mathrm{~mm}$ de comprimento para os grupos $1 \mathrm{e}$ 2 e $17 \mathrm{~mm}$ de comprimento para os grupos 3 a 6 . Os dentes foram 
restaurados com núcleos metálicos fundidos e coroas protéticas metálicas. Foram estudados os preparos ombro em $90^{\circ}$, ombro biselado e preparos em 130, com e sem $1 \mathrm{~mm}$ de remanescente dentinário oclusal à margem do preparo. Os resultados do teste de resistência à compressão demonstraram que independente do tipo de término, quando havia $1 \mathrm{~mm}$ de estrutura coronária envolvida pelo preparo, a resistência à fratura foi aumentada. Os autores também demonstraram que o remanescente axial do preparo é mais efetivo em aumentar a resistência à fratura do que o bisel isoladamente. Assim, complementam a definição de férula como uma banda metálica que envolve o término do preparo ou a parede axial do preparo, fornecido pela coroa protética e não pelo núcleo.

KING e SETCHELL ${ }^{74}$, em 1990, realizaram um experimento comparando o pino pré-fabricado de fibra de carbono com outros sistemas de pinos e núcleos. Para isso, utilizaram 40 incisivos centrais superiores, seccionados $2 \mathrm{~mm}$ acima do limite amelo-cementário, que receberam 4 diferentes tratamentos de reconstrução intracoronária e restauração indireta apresentando $1 \mathrm{~mm}$ de colar abraçando o remanescente dental. O primeiro grupo recebeu núcleo metálico fundido; o segundo, pino pré-fabricado metálico e núcleo fundido; o terceiro foi restaurado com pino pré-fabricado metálico e núcleo de compósito; e o último grupo, restaurado com pino de carbono e núcleo de resina. A carga de compressão foi aplicada por uma máquina universal de ensaios, num ângulo de $130^{\circ}$ em relação ao longo eixo do dente, a uma velocidade de $5 \mathrm{~cm} / \mathrm{min}$. Foram registradas as cargas necessárias para causar fratura e também o padrão de fratura dos 
espécimes. Os resultados mostraram haver diferença estatisticamente significativa entre os grupos restaurados com núcleos fundidos e com pinos de carbono e núcleo de resina. Os demais grupos não demonstraram diferença estatística entre si. Todos os espécimes sofreram fratura radicular com deslocamento do pino. Entretanto, o padrão de fratura foi significativamente mais favorável nos dentes restaurados com pino de fibra de carbono, se comparado ao grupo restaurado com pino pré-fabricado metálico.

Em 1990, LYONS $^{83}$, avaliou a máxima força de mordida dental alcançada. Para realização deste trabalho o autor utilizou-se de uma estrutura de aço inoxidável localizada entre os caninos que mensuravam a força de mordida dos pacientes neste local. Os resultados mostraram forças de mordida média na região de caninos em pacientes normais de $22 \mathrm{Kg}$ enquanto pacientes bruxomanos apresentavam média de $26 \mathrm{~kg}$. Ele ainda observou que as forças máximas de mordida encontrada na região de caninos em dois pacientes normais foram de 32 e $35 \mathrm{Kg}$.

McDONALD; KING; SETCHELL ${ }^{90}$, em 1990, analisaram os efeitos da restauração de dentes tratados endodonticamente com núcleos quanto a sua resistência à fratura. Os dentes foram divididos em três grupos, dentes restaurados endodonticamente sem núcleo, dentes restaurados com núcleo de aço inoxidável, e dentes restaurados com núcleo de fibra de carbono. Os núcleos foram cimentados com cimento resinoso. Os dentes foram submetidos à força no sentido de $90^{\circ}$ até que ocorresse a fratura. Os resul- 
tados não mostraram diferença estatisticamente significante entre os grupos analisados. Os autores concluíram que não há vantagens do ponto de vista da fratura mecânica em se restaurar dentes tratados endodonticamente com núcleos de aço inoxidável ou de fibra de carbono.

PEUTZFELD e ASMUSSEN ${ }^{108}$, em 1990, afirmaram que o risco de fratura de dentes restaurados com pinos intra-radiculares são fartamente descritos na literatura. Afirmam ainda, que o risco da fratura de um pino depende da sua resistência, marca comercial, metal, forma e diâmetro. Os autores, portanto, pesquisaram a resistência à flexão e fadiga de seis diferentes marcas comerciais de pinos intra-radiculares: Flexi-post, Filpost, Radix, Unimetric, Triax e Para-post. Ao final dos estudos os autores encontraram que os pinos Radix foram os mais resistentes à flexão e os pinos Unimetric foram os mais resistentes á fadiga.

WEINE et al. ${ }^{\mathbf{1 5 8}}$, em 1991, abordaram a longevidade clínica de núcleos fundidos num período de dez anos. Foram avaliados 138 casos, com o auxílio de radiografias e exames clínicos nos âmbitos periodontais, endodônticos e restauradores. De todos estes casos somente 6,35\% deles falharam. A partir dos resultados obtidos, os autores demonstram uma preferência por pinos fundidos levemente cônicos a pinos pré-fabricados paralelos, pois estes últimos removem a estrutura dentinária da porção apical do preparo e se adaptam perfeitamente ao formato do canal. Mas, apesar dos resultados superiores de adaptação, os pinos pré-fabricados não têm o mesmo desempenho clinicamente. 
Em 1991, KAHN ${ }^{69}$, afirmou que sem uma quantidade suficiente de estrutura dentária remanescente não deveríamos utilizar núcleos de preenchimento e sim núcleos metálicos fundidos. A estrutura dentinária remanescente é o fator chave para aumentar a resistência à fratura do elemento dentário. Existem aproximadamente 100 tipos de núcleos, sendo que todos apresentam vantagens e desvantagens, não há um sistema ideal. Geralmente a largura de um núcleo é determinada radiograficamente, no entanto, as raízes freqüentemente apresentam uma depressão no sentido mesiodistal que limita a largura na qual deveria ser confeccionado o núcleo, pois um núcleo largo resultará menor quantidade de dentina aumentando a possibilidade de fratura. Os dentes que apresentam este tipo de acidente anatômico são: incisivo central e lateral inferior, primeiro e segundo pré-molar superior, raízes palatinas e mesiovestibulares dos molares superiores e raízes mesiais e distais dos molares inferiores. A maioria dos núcleos pré-fabricados é circular e seu preparo em dentes que apresentam este tipo de depressão pode fazer com que as paredes de dentina fiquem muito finas. Segundo o autor um canal oval deveria receber um núcleo metálico fundido, pois neste caso ocorre uma redução mínima de estrutura dentária para criar espaço para o núcleo. Um núcleo ligeiramente cônico é preferido e para se evitar a formação da ação de cunha se deveria confeccionar um stop na área cervical.

HATZIKYRIAKOS; REISIS; TSINGOS ${ }^{54}$, em 1992, examinaram após três anos de tratamento, reconstruções realizadas com os seguintes tipos de pinos: pinos rosqueáveis, pinos paralelos serrilhados e pinos metálicos fundidos. De um total de 154 pinos, encontraram uma margem de sucesso de 
$94,5 \%$ para os três sistemas usados. Os insucessos foram atribuídos a dentes que serviam como retentores de próteses fixas e removíveis. Concluíram que, embora não encontrassem diferenças entre os sistemas testados, os pinos fundidos ainda permitem uma maior segurança ao profissional.

Em 1992, TROPE; RAY ${ }^{155}$ avaliaram a resistência à fratura de dentes tratados endodonticamente. Para isso utilizaram 48 caninos que tiveram seus condutos instrumentados seguindo diferentes técnicas. Os autores concluíram que os dentes que tiveram os condutos de suas raízes instrumentadas foram significantemente mais fracos que os dentes que não receberam instrumentação do canal radicular.

MILOT; STEIN ${ }^{95}$, em 1992, utilizaram 48 dentes análogos de plástico simulando dentes tratados endodonticamente para investigar a resistência à fratura. Três sistemas diferentes de núcleos foram usados, os metálicos fundidos, o Para-Post Plus e o Flexi-Post. Os corpos de prova foram submetidos a uma força oblíqua aplicada por lingual até que ocorresse a fratura. Os preparos biselados apresentaram maior resistência à fratura do que os outros tipos de preparo. Segundo os autores embora os núcleos metálicos fundidos sejam usados com mais freqüência tem aumentado o uso dos núcleos pré-fabricados. Dentro dos parâmetros analisados neste estudo os autores concluíram que quando a maioria da estrutura dentária é preservada o tipo de núcleo usado tem pouco ou nenhum efeito sobre a resistência da raiz; um preparo biselado e a conseqüente restauração final aumenta a resistência à 
fratura; um preparo não biselado apresenta uma maior incidência de fratura vertical.

Utilizando um modelo fotoelástico bi-dimensional ROLF et al. ${ }^{119}$, em 1992, avaliaram o estresse gerado por cinco modelos de pinos intraradiculares pré-fabricados. Sendo: 1) Para-post, pino rosqueado com sulco de escape para cimento não retido na dentina; 2) Beta-post, pino com roscas axiais com sulco de escape para cimento não retido na dentina; 3) Kurer Crown Anchor, pino com roscas em espirais sem sulco de escape e retenção em dentina através de roscas; 4) Flexi-post, pino com roscas transversais com sulco de escape e auto-rosqueável; 5) Radix Anker, pino com roscas em espirais com sulco de escape para cimento e auto-rosqueável. Para todos os modelos foram observados níveis de estresse. Para os sistemas Flexi-post e Radix Anker observaram-se quantidades mínimas, de esforço porém o pino Radix Anker apresentou a metade da retenção em relação ao Flexi-post e ao Kurer Crown Anchor. Nos núcleos cimentados Beta-post e Para-post foi comprovada a menor tensão entre todos os sistemas. Os sistemas que promoveram a melhor combinação de alta retenção e baixa tensão, foram o Radix Anker e o Flexi-post.

No ano de 1992, SEDGLEY e MESSER ${ }^{125}$, analisaram as propriedades biomecânicas de vinte e três dentes tratados endodonticamente e seus pares vitais contra-laterais. No estudo foram testadas as seguintes variáveis: resistência à tração, módulo de elasticidade, dureza e resistência à fratura. A análise estatística utilizando teste t pareado 
não revelou nenhuma diferença estatisticamente significante entre os dois grupos. Os autores afirmam que o tratamento endodôntico não torna o dente mais frágil, baseados nas similaridades existentes em propriedades biomecânicas entre dentes vitais e não vitais. E provam que fatores como perda de estrutura dental por cárie, acesso endodôntico, instrumentação endodôntica, traumas e preparos cavitários contribuem muito mais para a fragilidade do dente.

CAILLETEAU, RIEGER e AKIN ${ }^{21}$, em 1992, pretendendo determinar os efeitos da distribuição das tensões de um pino metálico cilíndrico nas paredes do canal radicular, utilizaram o método de elementos finitos. Para isto foram empregados quatro modelos bidimensionais de incisivos centrais superiores, incluindo ligamento periodontal e osso alveolar. O modelo um representava um dente intacto; o modelo dois um dente desvitalizado e restaurado com amálgama de prata; o modelo três restaurado com uma coroa total; e o modelo quatro, restaurado com pino e coroa total. Todos os materiais possuíam as mesmas propriedades (isotrópicos) e todos foram submetidos à força de $1 \mathrm{~N}$ na superfície lingual. Depois de feitos os testes, os autores, concluíram que o pino não distribui as tensões uniformemente ao longo da raiz. E que quando estes apresentavam paredes paralelas, observaram que a força de compressão gerou alta concentração de tensões junto ao seu término apical.

Numa revisão de literatura, GUTMANN ${ }^{50}$, em 1992 , considerou que as propriedades dos dentes despolpados e os conseqüentes procedimentos 
restauradores seriam responsáveis ou não pelo sucesso do tratamento. Enfatizou o uso de um mapeamento completo da anatomia e da biologia da dentina e raiz que passará pela restauração, pois procedimentos endodônticos e restauradores alteram estes tecidos duros. A dentina de dentes despolpados se modifica em sua estrutura interna, o que diminui a resistência ao estresse e flexibilidade e, devido à perda de umidade e estrutura do dente, técnicas de preenchimento da raiz requerem procedimentos restauradores especiais relacionados à anatomia radicular e osso suporte. A preservação da estrutura dentária apresenta-se como o fator de maior importância para a resistência à fratura do dente tratado endodonticamente. A utilização de pinos intra-radiculares só é indicada no caso de retenção e estabilização do núcleo coronário e não para reforçar raízes fragilizadas.

No trabalho de HUANG, SCHILDER e NATHANSON ${ }^{62}$, publicado em 1992, foram analisadas espécimes de dentina, entre dentes vitais e dentes tratados endodonticamente, com o objetivo de determinar se há diferença significativa entre as propriedades mecânicas da dentina entre ambos. As propriedades mecânicas foram avaliadas depois das amostras serem submetidas a diferentes situações como testes de compressão, tração e impacto. Os resultados deste estudo permitiram concluir que a desidratação após o tratamento endodôntico não enfraquece a dentina, porque não houve diferença estatisticamente significante na resistência à compressão e tração dos dentes despolpados contrapostos aos dentes vitais. 
SORNKUL et al. ${ }^{141} 1992$, propôs avaliar a resistência à fratura de raízes de pré-molares inferiores com e sem tratamento endodôntico. Ele observou que as raízes não tratadas mostraram as mais altas resistências às fraturas e concluiu que os fatores importantes para se evitar fraturas seriam a quantidade de estrutura dentária remanescente; resistência do pino, e sistema adesivo entre material de preenchimento e dentina.

BEX et al. $^{16}$, em 1992, compararam a resistência á força de cisalhamento de dentes anteriores superiores tratados endodonticamente e reforçados com núcleo metálico fundido ou núcleos de resina composta (Adaptic) e adesivo dentinário (Oxalato férrico, NTG-GMA e PMDM, sistema desenvolvido por BOWEN). Os dentes foram montados em uma máquina de testes em ângulo de 90․ Através dos resultados concluíram que apesar dos núcleos metálicos fundidos serem cerca de três vezes mais resistentes que os núcleos de resina composta estes mostraram que necessitam de grande força para falharem podendo ser bastante satisfatórios. Os autores também concluíram que os núcleos de resina composta geralmente têm falha coesiva não ocorrendo fratura radicular o que não acontece com os núcleos metálicos fundidos que, geralmente ocasionam fratura radicular, portanto, os núcleos de resina composta, segundo os autores, quando falham são passíveis de sofrerem uma nova restauração o que nem sempre ocorre com os núcleos metálicos fundidos.

MORGANO e MILOT $^{97}$, em 1993, analisando resultados clínicos de pinos metálicos fundidos, observaram que o insucesso do tratamento pode 
ocorrer por falha de retenção devido ao comprimento, folga dentro do conduto, contaminação do cimento com saliva, resíduos de lubrificantes ou cimento temporário e também por fratura na raiz. Recomendam a utilização dos núcleos metálicos nos dentes anteriores e posteriores que perderam estrutura dental coronária. E aconselhando a utilização de pinos fundidos os mais longos possíveis, respeitando-se quatro a cinco milímetros de obturação endodôntica. Ainda com relação à fratura, os autores, à atribuem ao desenho do pino, paredes paralelas, exagerada pressão hidráulica durante a cimentação, bolhas durante a fundição. A incidência destes fatores diminui quando uma atenção especial é dada à adaptação dos pinos dentro do conduto.

LINDHE $^{81}$, no ano de 1993, utilizou resina composta associada à ancoragem com pinos intra-radiculares pré-fabricados para a construção de núcleo de preenchimento em tratamentos endodônticos. A resina composta seria o material mais indicado para a reconstrução de raízes muito fragilizadas. O autor chamou a atenção para a dificuldade de fotopolimerização em áreas de difícil acesso, que faria com que estas partes ficassem com resistência inferior, dessa forma recomendou o uso de resina composta autopolimerizável.

Com o objetivo de determinar a forma ideal de restaurar um dente tratado endodonticamente ROBBINS et al. ${ }^{118}$, em 1993, selecionaram 60 caninos que sofreram um corte perpendicular na junção cemeto-esmalte e foram montados em um cilindro de PVC em resina acrílica com $2 \mathrm{~mm}$ de 
dente externamente. Foram divididos em 6 grupos de 10 dentes cada: A) Pinos intra-radiculares cilíndricos cimentados com ionômero de vidro 9mm dentro do canal e $4 \mathrm{~mm}$ para fora e pino intra-dentinário com núcleo de amálgama; B) Pino intra-radicular cônico, pino intradentinário e núcleo de amálgama como no grupo $\mathrm{A}$; C) Apenas guta percha no canal radicular. D) Guta percha no canal e resina composta na câmara pulpar; E) Apenas pino cônico cimentado no canal da mesma forma que nos grupos A e B; F) Dentes sem nenhum tratamento (controle). Todos os dentes receberam uma coroa total fundida em ouro sendo posteriormente montado em um ângulo de $45^{\circ}$ após o que foram sujeitos a uma força de compressão em uma máquina de ensaios Universal. Os autores concluíram que não houve diferença estatística na resistência à fratura dos dentes restaurados com pinos cilíndricos ou cônicos. Não houve diferença estatística entre os grupos mas os autores alertam que a remoção de estrutura dental sadia enfraquece o dente mesmo que o reforcemos de alguma forma.

CHANG; MILSTEIN ${ }^{25}$, em 1993, estudaram o efeito da parte coronária de três pinos pré-fabricados na resistência à fratura de três materiais para núcleos de preenchimento. Selecionaram 360 amostras padronizadas para receberem os pinos Parapost, Flexi-post e Unitypost, associados aos materiais restauradores amálgama de prata, resina composta e resina reforçada com partículas de titânio. Além dos materiais, foi avaliada a variação da espessura do material restaurador sobre os pinos pré-fabricados, em 1 e 3 $\mathrm{mm}$. Foram realizados o teste de carregamento compressivo e o teste de resistência à tração, diretamente sobre os núcleos de preenchimento. Os re- 
sultados demonstraram que o pino Flexi-Post apresentou os melhores resultados nos testes de resistência à compressão e a tração, por possuir maior número de retenções na sua porção coronária. O material restaurador resina composta apresentou resultados superiores ao amálgama e a resina reforçada com partículas de titânio, e atribuem, em parte, a associação com sistemas adesivos. Concluíram que uma espessura de $3 \mathrm{~mm}$ sobre o pino é melhor que $1 \mathrm{~mm}$ apenas, sob carregamento compressivo, e que a mesma variação não apresentou diferença em teste de resistência à tração.

Neste mesmo ano, HO et al. ${ }^{58}$, relataram os efeitos dos núcleos na distribuição do estresse sobre a dentina de dentes despolpados, utilizando um elemento de análise finita. Foi usado um modelo tridimensional de um incisivo central superior Chinês intacto, com e sem uma restauração com núcleo. Quando o dente era submetido a forças mastigatórias ou cargas traumáticas a distribuição do estresse na dentina era semelhante possuindo ou não uma restauração com núcleo. Esta forma de análise de estresse sugere que um núcleo, comparado com terapias mais conservadoras pode não diminuir o estresse dentinário em incisivos tratados endodonticamente e possivelmente em outros dentes. Então os efeitos benéficos de reforço radicular com núcleo nestes dentes podem ser duvidosos.

Em 1994, KAHN, et al. ${ }^{70}$, compararam a resistência a fadiga de três sistemas de núcleos rosqueáveis pré-fabricados, para analisar se o desenho pode ter influenciado sobre a resistência à fratura de dentes tratados endodonticamente. As raízes dos dentes humanos foram restauradas com os di- 
ferentes tipos de núcleos rosqueáveis, a porção coronária foi reconstruída com amálgama e coberta com uma coroa cimentada. Os espécimes foram submetidos a termociclagem antes de serem testados em uma máquina de teste Instron até a fratura. Não houve nenhuma diferença estatisticamente significativa entre os pinos rosqueáveis testados. Segundo os autores os dentes em função são submetidos a vários fatores inter-relacionados que incluem aspectos morfológicos, posição na arcada e fatores proté ticos e oclusais. Os fatores que deveriam ser considerados na escolha do tipo de núcleo são retenção, distribuição do estresse, resistência à fratura da raiz e fratura do pino. Um conduto preparado com um mínimo desgaste resulta em maior quantidade de dentina remanescente e pode proporcionar maior resistência à fratura, dessa forma deveria se evitar o uso de núcleos muito largos e de pequeno comprimento, pois estes podem elevar a concentração de estresse na região cervical. A preservação do máximo possível de estrutura coronária remanescente aumenta de forma significativa a resistência à fratura do elemento dentário. A colocação de uma coroa tem demonstrado distribuir as forças de forma mais iguais do que quando o núcleo é testado sem a utilização desta, demonstrando que a concentração de forças atua em áreas diferentes. Os dentes em estado naturais também absorvem melhor as forças de mastigação, pois apresentam a resiliência do ligamento periodontal e osso adjacente. Outro fator a se considerar é o fato de que a máquina de testes aplica forças continuas em uma única direção para um pequeno ponto da coroa, contudo, as forças mastigatórias não são unidirecionais e são aplicadas repetidamente em uma grande área de superfície. Os autores concluí- 
ram que os dentes tratados endodonticamente que apresentem remanescente dentinário não deveriam ser restaurados com núcleos pois estes não contribuem para aumentar a resistência à fratura.

Para comparar a retenção e estabilidade dos sistemas de pinos intraradiculares pré-fabricados Flexi-post, Para-post e Brasseler, KEYF e SAHIN $^{73}$, em 1994, selecionaram 42 raízes de incisivos superiores tratadas endodonticamente. Cada pino foi cimentado no canal com cimento de fosfato de zinco e o teste dividido em duas fases: na primeira, uma força tensional foi aplicada ao longo do eixo de cada dente até o deslocamento do pinonúcleo. Nesta fase observourse que, quanto à resistência a tração, em pinos de diâmetros médio e grande, a diferença foi bem mais significante do que em pinos de diâmetros menores. Pinos Flexi-post (médios) mostraram-se duas vezes mais retentivos que os outros. Na segunda fase foi aplicada uma carga tangencial de compressão, num ângulo de $130^{\circ}$, e, novamente, pinos Flexi-post mostraram-se mais estáveis que os demais.

RUEGGEBERG; CAUGHMAN e CURTIS ${ }^{121}$, também em 1994, realizaram um trabalho com o objetivo de pesquisar a interdependência da duração e da intensidade da exposição na polimerização, em várias profundidades, das resinas compostas. Os resultados mostraram uma relação muito grande entre a profundidade e a polimerização de resinas compostas. Em profundidades maiores do que $2 \mathrm{~mm}$ os resultados de polimerização foram pobres estando muito susceptíveis às mudanças da intensidade de luz e do tempo de exposição. Os autores concluíram que, 
para uma polimerização uniforme, a exposição de tempo recomendada é de 60 segundos em uma intensidade mínima de $400 \mathrm{~mW} / \mathrm{cm}^{2}$ e a espessura de cada incremento não deve exceder $2 \mathrm{~mm}$, com $1 \mathrm{~mm}$ sendo a ideal.

Em 1994, LEVARTOVSKY et al. ${ }^{79}$ compararam a resistência mecânica de três materiais empregados como núcleo de preenchimento: resina composta (FLÚOR-CORE), ionômero de vidro fotopolimerizável (Variglass VLC) e um ionômero de vidro reforçado com prata (Miracle Mix). Os corpos de prova foram obtidos de acordo com a especificação n.27 da A. D. A, sendo que as propriedades avaliadas foram: resistência à compressão, tração e cisalhamento. Após 24 horas de conservação em 100\% de umidade a $37^{\circ}$, as amostras foram testadas em uma máquina de testes universal Instron. Através dos resultados obtidos os autores puderam concluir que a resina composta Flúor-Core apresentou os melhores resultados seguida pelo Variglass e por último, com resultados bem inferiores, o cimento de ionômero de vidro Miracle Mix sendo que é salientado por estes autores que este material não apresenta propriedades satisfatórias que justifiquem o seu emprego como material para núcleo de preenchimento.

Com o objetivo de tentar esclarecer se a utilização de um núcleo intra-radicular aumentaria a resistência de um remanescente dentinário, ASSIF; GORFIL ${ }^{\mathbf{5}}$, em 1994, publicaram um artigo sobre as propriedades biomecânicas deste tipo de terapêutica. Relataram que apesar de ser dito que um núcleo protege e reforça o dente contra as forças mastigatórias pela favorável distribuição da força no interior da dentina radicular e pela sua dissi- 
pação ao longo dos tecidos adjacentes, a resistência estrutural de um dente depende muito mais da quantidade, resistência e da integridade da dentina remanescente. O problema fundamental estaria ligado a remoção de estrutura dentinária envolvida nos vários tipos de procedimentos. Dentes despolpados suportariam melhor as forças oclusais do que os dentes reforçados através de vários tipos de núcleos. Não seria necessário reforçar o dente com núcleos após o tratamento endodôntico, mas é essencial não enfraquecê-lo desnecessariamente. A conservação de dentina e a confecção de restaurações embasadas neste conceito são preferíveis. Cita ainda que os núcleos cilíndricos têm ângulos agudos em suas porções terminais onde as forças são concentradas. Estes núcleos exerceriam forças compressivas na porção apical da raiz junto aos ângulos agudos do núcleo e podem provocar fraturas dentinárias nesta região. A preparação do conduto levaria a remoção de dentina onde esta é menos espessa e a concentração de forças é maior, e aumentando o risco de perfurações radiculares. Já núcleos cônicos exibiriam menor concentração de estresse na porção apical, provavelmente devido a ausência de ângulos agudos e a conservação de estrutura dentinária. Os núcleos construídos com o objetivo de aumentar a retenção intra-radicular poderiam comprometer o prognóstico do dente restaurado. Por esta razão os núcleos deveriam ser utilizados somente quando não houvesse outra alternativa. Sugerem que as experiências feitas para os sistemas de pinos são questionáveis porque não refletem condições clínicas específicas, porque a porção coronária do pino fica recoberta com coroa total e que, como a coroa altera a distribuição de forças para as raízes, seria esta coroa quem garanti- 
ria a proteção da raiz contra fratura. Sendo assim, o tipo de pino tem pouca influência na resistência à fratura.

COHEN et al. $^{30}$, em 1994, estudaram a resistência à fratura de três diferentes materiais de preenchimento suportados por três diferentes marcas comerciais de pinos intra-radiculares. Os autores selecionaram dentes uni-radiculares recém extraídos que tiveram seus canais radiculares obturados antes de receberem três diferentes pinos intra-radiculares: Flexi-post, Vlock e Para-post. Após a cimentação dos pinos reconstruiu-se as coroas dentárias com resina composta (ti-Core), amálgama (TYNin) e ionômero de vidro (Ketac silver). Os dentes foram montados em cilindros de resina acrílica antes de serem colocados em um ângulo de $45^{\circ}$ para os testes de resistência em uma máquina de ensaios. Ao final do estudo os autores encontraram ser os pinos Flexi-post e Vlock os que forneceram maior resistência ao dente vindo por último os pinos Para-post. Em relação aos materiais de preenchimento as resinas compostas foram os mais resistentes, superando o amálgama, que foram destacados pelos autores como materiais frágeis que precisam de volume, sendo, portanto, enfraquecidos pela presença de pinos. Os núcleos de Ketac-silver foram os menos resistentes, o que segundo os pesquisadores é devido a sua baixa resistência à compressão.

MANNING et al. ${ }^{84}$, em 1995, revisaram conceitos teóricos que devem ser considerados para a reconstrução de dentes tratados endodonticamente com pinos e núcleos. Como os dentes despolpados são mais friáveis que 
dentes vitais - por causa da perda de umidade e de prováveis alterações na sua morfologia - deve-se considerar esta fragilidade com relação à aplicação de cargas que aumentam o risco de fratura. Outra característica é o risco relacionado à anatomia radicular para a acomodação de um pino, que se não observada, pode predispor raízes finas às perfurações e fraturas. Os autores salientaram que a resistência do remanescente também se deve à quantidade de estrutura dentinária preservada. Afirmando, que pinos intraradiculares não contribuem para o aumento da resistência à fratura e, ainda, que este só devem ser utilizados em caso de retenção para o núcleo e coroa protética onde ocorre grande perda de estrutura dental coronária.

No mesmo ano, MANNING et al. ${ }^{85}$, publicaram a parte II, onde discutem as aplicações clinicas destes conceitos básicos. Segundo os autores a colocação de um núcleo não reforçará um elemento que apresente suficiente estrutura dentária. A necessidade de colocação de um núcleo deveria ser analisada em função da quantidade de dentina remanescente após a redução dentinária exigida pelo tipo de restauração a ser utilizada; uma espessura mínima de $1 \mathrm{~mm}$, é necessária para dar rigidez suficiente para que o remanescente dentinário suporte as forças mastigatórias, espessuras menores deveriam ser removidas e deveria se avaliar a largura e profundidade da câmara pulpar. Para a confecção do núcleo os autores recomendam que a remoção da guta percha é mais segura se realizada com instrumentais aquecidos devido ao aumento potencial de micro infiltração provocada pela remoção química e o possível deslocamento do selamento apical que poderia ocorrer durante a remoção mecânica. A preservação da estrutura denti- 
nária remanescente deveria nortear o tipo de desgaste a ser realizado na porção coronária, se possível a remoção deve se limitar a dentina sem suporte e a quantidade exigida pelo tipo de restauração a ser confeccionada. A utilização de artifícios para a orientação da força no sentido do longo eixo do dente, tal como os sulcos anti-rotacionais minimizam a concentração de estresse principalmente no interior do conduto radicular. O tipo de núcleo mais adequado, pré-fabricado ou fundido, deveria ser escolhido baseado na quantidade de estrutura remanescente e o tipo de estresse oclusal a qual será submetido. No entanto, os autores concluem que cada vez se torna mais difícil a escolha do tipo de material em virtude da grande quantidade de materiais que têm aparecido.

TORBJÖRNER et al. ${ }^{152}$, em 1995, publicaram um estudo de avaliação de dez anos, feitos em 638 pacientes. Procurando analisar o comportamento de 788 dentes tratados endodonticamente. Verificaram que 456 dentes receberam núcleos metálicos fundidos e 332 receberam pinos pré-fabricados. Os autores avaliaram o percentual de falhas e o padrão de fratura. Depois de um período de quatro a cinco anos foram detectadas falhas de $15 \%$ para núcleos metálicos fundidos e de $8 \%$ para pinos préfabricados, sendo que a retenção foi a falha mais comum em ambos os grupos. Analisando fraturas com a indicação de extração, registrou um percentual de $5 \%$ para núcleos metálicos fundidos e $2 \%$ para pinos préfabricados. No total geral, setenta e dois dentes falharam, mas, a causas pelas quais ocorreram estas falhas não foram estudadas. 
Comparando a resistência à força torcional em sete diferentes sistemas de pinos pré-fabricados metálicos, COHEN et al. $^{31}, 1995$ estudaram o comportamento destes pinos em 150 raízes de incisivos centrais e laterais. Segundo os autores, a força torcional foi escolhida por ser o melhor método para comparar a estabilidade dos pinos pré-fabricados. Os pinos metálicos avaliados nesta experiência foram: Flexi-post; Flexi-flange; Para-post; Vlock-post; Access-post; Dentatus; World-post. Todos cimentados com cimento de fosfato de zinco e cimento resinoso Flexi-flow. As amostras foram divididas em onze grupos e submetidas à forças torcionais no sentido horário. Os pinos Flexi-post e Flexi-flage, cimentados com fosfato de zinco e cimento resinoso, demonstraram resistência significantemente maior contra as forças de torção.

Em 1995, ISHIKIRAMA et al. ${ }^{65}$ verificaram a resistência à fratura de dentes tratados endodonticamente com suficiente remanescente dentário, com ou sem pino intracanal, restaurados com Scotchbond 2 e resina composta P50. Selecionaram incisivos centrais superiores de dimensões semeIhantes os quais constituíram quatro grupos experimentais de 20 corpos de prova, com e sem pino intracanal, de aço inoxidável, de $1 \mathrm{~mm}$ de diâmetro, o qual foi posicionado $7 \mathrm{~mm}$ aquém do ápice, sendo cimentado com fosfato de zinco; as cargas oblíquas foram aplicadas com um ângulo aproximado de $130^{\circ}$ em relação ao longo eixo dentário, em dois locais distintos: centro da porção linguoincisal e no centro da restauração de resina composta da face lingual. Encontraram diferenças numéricas entre as resistências à fratura dos dentes nas diferentes condições experimentais, mas apenas os diferen- 
tes locais de aplicação da força se mostraram estatisticamente significativos. Quando aplicaram carga linguoincisal a média de fratura no grupo com pino foi de 19,17 kg e de $17,04 \mathrm{~kg}$ sem pino; com carga no centro da restauração, a presença do pino ofereceu média de 59,39kg e, sem ele, 64,16kg. Seus achados permitiram a conclusão de que não houve diferença estatisticamente significativa na resistência à fratura quando os dentes eram tratados endodonticamente, com ou sem pino intracanal e que essa significância ocorreu em função do local da aplicação da força e salientaram que o uso de pino intracanal não foi capaz de reforçar os dentes.

Em 1996, CHRISTENSEN ${ }^{27}$, procurou analisar a necessidade da colocação de pinos intra-radiculares em dentes tratados endodonticamente e, se realmente aqueles quando cimentados no canal eram capazes de fortalecer estes dentes. Afirma que a principal função dos pinos é promover a retenção para a restauração protética em dentes onde o tecido coronário foi perdido. Nos dentes tratados endodonticamente com perda mínima de estrutura dental, o autor recomenda a restauração com materiais ionoméricos, resinosos ou com amálgama de prata, sem a instalação de pinos no interior do canal, quando a perda de estrutura coronária é pequena. A restauração protética com pinos e núcleos só deve ser utilizada em casos extremos, como, em dentes que perderam mais da metade da coroa dental. Nesta situação pinos pré-fabricados e núcleos de preenchimento tornam-se os mais indicados.

Em 1996, ABDALLA e ALHAYDAINY' avaliaram o desempenho 
clínico de três resinas compostas em restaurações classe I de pré-molares, classificando a resina Z-100 como de melhor desempenho quando avaliada a integridade marginal, o manchamento marginal, descoloração e forma anatômica. Na sua discussão, os autores atribuem o superior desempenho ao alto conteúdo de carga incorporada à matriz, possível devido ao tamanho e forma das suas partículas, totalizando $66 \%$ do seu volume. Este maior conteúdo de carga inorgânica corresponde à máxima resistência a compressão, dureza superficial e resistência ao desgaste. Além disso, seu Módulo de Young é semelhante ao da dentina, tornando o dente restaurado resistente às cargas oclusais.

Para comparar a distribuição do estresse fotoelástico em quatro tipos de pinos endodônticos COHEN et al. $^{32}$, em 1996, realizaram um estudo aplicando cargas verticais e obliquas, num ângulo de 26을 sobre dentes restaurados com pinos rosqueáveis. Os sistemas avaliados foram o Flexipost, Flexi-flage, Para-post e Access-post. Os resultados mostraram que mesmo sem nenhum tipo de cargas os pinos provocam um pequeno estresse, que quando submetidos à carga vertical os pinos foram considerados excelentes. Os pinos Para-post apresentaram respostas assimétricas em todos os testes, porem com uma maior concentração de estresse na região apical.

Avaliando o comportamento de limite de carga de pinos Flexi-post, Flexi-flange, Para-post, Access-post e C-post, restaurados com amálgama de prata-Tyntin, resina composta reforçada com titânio (Ti-Core) e ionômero 
reforçado por prata (Ketac-Silver e ionômero modificado - G.C Miracle Mix) COHEN et al. ${ }^{33}$, em 1996, concluíram que a maior resistência aconteceu nas restaurações com amálgama/Para-post. O pior resultado foi com o grupo Ketac Silver / Para-post e que a grande maioria das falhas (79\%) ocorreram no núcleo de preenchimento. Em $21 \%$ dos casos ocorreram fratura do dente, e que em nenhuma situação se evidenciaram falhas nos pinos.

MORGANO $^{98}$, em 1996, analisando métodos de restauração em dentes despolpados afirmou que pinos intra-radiculares não devem ser utilizados para reforçar a estrutura remanescente que sua indicação deve estar restrita em casos, em que há estrutura inadequada para reter uma restauração coronária.

HOLMES; DIAZ-ARNOLD e LEARY ${ }^{60}$, em 1996, citaram em trabalho de Modelo de Elemento Finito os valores para módulo de elasticidade das diversas estruturas dentais e alguns em gpa: dentina $=18,6$; cemento $=$ 18,6 ; ligamento periodontal $=0,0689$; osso cortical $=13,7$; osso trabecular $=$ 1,37 ; gengiva $=0,003 ;$ ouro fundido $=96,6 ;$ porcelana $=69 ;$ cimento de fosfato de zinco $=22,4$. Os autores simularam a inserção de um núcleo metálico fundido em um dente cujo remanescente dentinário permitia a confecção de uma férula de $2 \mathrm{~mm}$ na parte coronal. $\mathrm{O}$ estudo demonstrou que o pico compressivo e estresse por tração ocorreram no terço coronário da dentina. O pico de estresse de cisalhamento ocorreu adjacente ao pino intra-radicular no terço médio da raiz. A magnitude do estresse de cisalhamento foi influenciada pelo tamanho do pino intra-radicular. Com o 
aumento do pino intra-radicular, ocorria diminuição do estresse de cisalhamento no terço médio da raiz.

COHEN et al. ${ }^{34}$, 1997, compararam a resistência à fratura de 3 materiais utilizados para reconstrução coronária (resina composta (Ti- Core), amálgama de prata (Tytin), e cimento de ionômero de vidro híbrido (Advance)), sobre pino pré- fabricado rosqueado com fenda (Flexi-Flange) e com pinos dentinários sem núcleo intra-radicular. Foram usados 60 dentes unirradiculares recém - extraídos divididos em 6 grupos com 10 amostras , que receberam forças de compressão num ângulo de $45^{\circ}$ com velocidade de $0,63 \mathrm{~mm} / \mathrm{minuto}$. Obteve-se uma diferença estatisticamente significante entre os materiais restauradores, mas não relacionada aos pinos. A resina composta teve um limiar médio de resistência à fratura maior do que o amálgama e o ionômero de vidro, sendo que estes não tiveram diferenças estatisticamente significantes entre si. Também não foram verificadas diferenças estatísticas entre a resina suportada por pino ou não. Embora os pinos não terem sido cobertos com coroas totais neste estudo, os autores consideram que os resultados obtidos foram relevantes porque as resistências das restaurações foram testadas no pior tipo de situação .

SMITH e SCHUMAN ${ }^{133}$, em 1997, elaboraram um guia de procedimento para auxiliar na restauração de dentes tratados endodonticamente. Baseando-se na quantidade de estrutura coronária remanescente, com o objetivo de otimizar a função e a estética do dente a ser tratado. No caso de um dente possuir um mínimo de comprometimento 
da porção coronária e estético seria indicado uma restauração direta com resina composta ou cimento de ionômero de vidro reforçado com prata. Quando for o caso de se utilizar pinos intra-radiculares estes devem ser de acordo com a configuração do canal radicular. Os autores reconhecem que uma decisão correta, em certos casos, é um processo complicado, pois, existem poucos resultados clínicos em longo prazo avaliados até o momento.

MARCHI ${ }^{86}$, em 1997, comparou a resistência à fratura de raízes integras e debilitadas restauradas através de núcleos fundidos ou pinos préfabricados metálicos. Para fixar as amostras desenvolveu uma base metálica com um plano inclinado de $45^{\circ}$, cujo centro possuía uma perfuração central para fixação dos blocos de resina que continham as amostras. Desta maneira, a ponta metálica incidia o carregamento compressivo formava um ângulo de $135^{\circ}$ em relação à superfície palatina das amostras. A análise estatística dos dados demonstrou que pinos pré-fabricados apresentaram resistência superior ao núcleo fundido quando cimentado em raízes debilitadas não apresentando diferença estatística quando comparados em raízes integras. Concluíram também que o agente adesivo associado à resina composta foi efetivo em reforçar raízes debilitadas.

SIDOLI; KING e SETCHELL ${ }^{130}$, em 1997, compararam o desempenho e a resistência à fratura de pinos de fibra de carbono (C-post) em relação aos pinos metálicos e núcleos em resina composta. Foram selecionados 40 incisivos centrais e caninos superiores, divididos em 4 
grupos com os seguintes tratamentos: dentes restaurados com Gpost e núcleo de resina, dentes restaurados com pino metálico e núcleo em resina; dentes restaurados com núcleo metálico fundido e dentes íntegros onde foi realizado tratamento endodôntico. Todas as amostras foram recobertas com restaurações protéticas, cimentadas com fosfato de zinco. A carga de compressão foi aplicada num ângulo de $50^{\circ}$ em relação ao longo eixo do dente, à velocidade de $5 \mathrm{~cm} / \mathrm{min}$. Os dentes somente com acesso endodôntico mostraram resistência à fratura superior aos demais grupos, seguidos dos dentes restaurados com núcleos metálicos fundidos e pinos pré-fabricados, que não mostraram diferença estatística entre si. Foram encontrados resultados inferiores quando se utilizou o pino de fibra de carbono. O padrão de fratura foi examinado macroscopicamente e microscopicamente, sendo que os melhores resultados foram para os pinos de carbono, seguido dos pré-fabricados, que se mostraram compatíveis com a reconstrução dental após fratura.

Em 1997, BAHARAV et al. $^{6}$ analisaram o efeito do tempo de irradiação nas propriedades de tensão de dureza e resistência das resinas compostas. Os autores utilizaram materiais que continham grande quantidade de partículas de carga, e que eram muito friáveis. Assim, os escolhidos foram a Herculite XRV (Kerr), Brilliant (Coltene) e P-50 (3 M). Um molde cilíndrico de politetrafluoretileno com $2 \mathrm{~mm}$ de espessura, com uma extensão de $4 \mathrm{~mm}$, foi preenchido com resina composta, tampado com fitas de poliéster nas extremidades. A ponta da unidade de luz ativadora foi colocada em cima da fita de poliéster. O material era irradiado por 20, 40, 80 
ou 120 segundos. Num total de 120 espécimes, dez espécimes foram preparados para cada combinação de material e tempo. Antes do teste, os corpos de prova foram armazenados em $100 \%$ de umidade, a $37^{\circ} \mathrm{C}$, por 24 horas. Os corpos de prova foram submetidos a tensão diametral com uma máquina de teste universal a uma velocidade de $0,5 \mathrm{~cm}$ por min. Os materiais não diferiram significativamente entre si quanto à resistência à tensão diametral, mas diferiram quanto à dureza. Houve diferença significativa considerando o tempo de irradiação por 20 segundos com os outros tempos, ou seja, irradiar por 40, 80 ou 120 segundos não alterou a dureza significativamente.

SMITH; SCHUMAN e WASSON ${ }^{134}$, em 1998, estudando a relação pino/conduto/cimento, concluíram que os núcleos metálicos fundidos devem ser utilizados nos casos de canais radiculares elípticos ou excessivamente alargados e pinos pré-fabricados são compatíveis em dentes com canais circulares pequenos. Com relação aos materiais para preenchimento, a resina composta mostra uma adequada resistência mecânica, capacidade de polimerização e rápida cura, mas, esbarram na tendência a microinfiltração. O amálgama é fácil de manipular, apresenta alta resistência à compressão e baixa característica de microinfiltração, mas, sua desvantagem maior é a demora e a pouca capacidade de adesão. O ionômero de vidro, apesar de apresentar adesividade à estrutura dentária, liberação de flúor e baixo coeficiente de expansão térmica, não é um material resistente. 
Em 1998, McLEAN ${ }^{91}$, publicou um estudo que apresentava uma técnica direta para a restauração de dentes tratados endodonticamente. Ele considerava que a única função de um pino intra-radicular é promover a retenção para a reconstrução coronária e, que esta, ainda pode ser considerada ativa ou passiva. Os núcleos ativos são aqueles que oferecem uma retenção adicional que promove um engajamento mecânico na dentina. Os núcleos passivos são os paralelos ou os cônicos, pré-fabricados e fundidos, sendo que os paralelos oferecem maior retenção. O autor afirma que, se for realmente necessária a utilização de um pino, que este seja um de menor diâmetro, paralelo, de retenção passiva, com comprimento igual ou maior que a coroa clínica, cimentado com fosfato de zinco ou cimento híbrido de resina/ionômero de vidro, deixando um vedamento apical de $4 \mathrm{~mm}$.

PEGORARO et al. ${ }^{105}$, em 1998, em seu livro de Prótese Fixa recomendaram que nos casos de grande destruição coronária, nos quais o remanescente não é suficiente para promover resistência estrutural ao material de preenchimento, deve-se indicar os núcleos metálicos fundidos. Comentaram que quando não existe remanescente dentinário suficiente, devese preparar uma caixa no interior da raiz com aproximadamente $2 \mathrm{~mm}$ de profundidade para criar-se uma base de sustentação para o núcleo. A finalidade desta caixa seria para direcionar as forças no sentido apical diminuindo as tensões nas paredes laterais da raiz. O comprimento ideal do pino mais seguro seria de 2/3 do suporte da raiz do dente envolvido, pois consideraram 
que o comprimento correto do núcleo no interior da raiz é sinônimo de longevidade da prótese.

Para analisar a resistência à fratura de raízes tratadas endodonticamente, utilizando duas técnicas diferentes de restauração, FRAGA, et al. ${ }^{43}$, em 1998, realizaram um estudo in vitro utilizando 27 raízes de dentes unirradiculares, recém extraídos, com diâmetro cervical semelhante. Dois grupos foram montados, sendo que o primeiro grupo, com 14 amostras, recebeu núcleos metálicos fundidos e o segundo grupo, com as 13 amostras restantes, pinos pré-fabricados e núcleo de resina composta. Em ambos os grupos o comprimento do pino intra-radicular foi de $8 \mathrm{~mm}$ e a cimentação feita com cimento de fosfato de zinco. Mediante à aplicação de uma carga à 45ำ em relação ao longo eixo do dente, o grupo 1 apresentou maior resistência à fratura. Apesar deste resultado, o estudo ainda aponta para os núcleos pré-fabricados reconstruídos com resina composta como o sistema mais recomendável, porque, todas as falhas ocorreram na estrutura de resina e isto possibilitou a proteção da dentina radicular.

AKKAYAN \& CANIKLIOGLU², em 1998, avaliaram a resistência à fratura de dentes restaurados com diferentes sistemas de pinos intraradiculares. Os pinos Flexi-post, Parapost e Filpost foram fixados ao canal de caninos superiores através de cimento de fosfato de zinco. Os núcleos de preenchimento foram confeccionados em ionômero de vidro convencional. Foi introduzido um grupo com núcleo de preenchimento porém sem pinos intra-radiculares. No grupo controles foram cimentados núcleos metálicos fun- 
didos. Todos os preparos foram recobertos com coroas protéticas metálicas abraçando $1 \mathrm{~mm}$ do término em dentina. As amostras receberam uma camada de material de moldagem a base de silicona para simular o ligamento periodontal. Após isto, foram incluídas em resina para serem submetidas ao carregamento tangencial de compressão, a $130^{\circ}$ e velocidade de $1 \mathrm{~mm} / \mathrm{min}$. Os resultados mostraram diferença estatística entre os grupos: a menor média foi para o grupo restaurado apenas com núcleo de ionômero de vidro, seguido respectivamente pelo grupo do Filpost, núcleo metálico fundido, Parapost e, com melhor média, o grupo do Flexi-post. O estudo do padrão de fratura demonstrou predomínio de fraturas oblíquas entre os terços médio e gengival da raiz, porém, no grupo dos núcleos fundidos houve alto índice de fraturas longitudinais. O padrão de fratura mais favorável á reconstrução foi demonstrado pelo grupo do Flexi-post. Em sua discussão comentam a importância em se realizar a cobertura da raiz com um material elástico que permita a movimentação da raiz, o que pode alterar a distribuição de tensões durante o teste. Concluem que o pino Flexi-post demonstrou a melhor resistência à fratura e o padrão de fratura mais coronário em relação aos demais sistemas de retenção para a coroa protética.

ZALKIND e HOCHMAN ${ }^{160}$, em 1998, comentaram que os núcleos fundidos são indicados quando não há estrutura dentária remanescente suficiente para utilizar os núcleos pré-fabricados. Entretanto, quando a raiz permite e existe quantidade suficiente de dentina, os pinos pré-fabricados podem ser empregados. Além da fácil manipulação e rápido endurecimento os pinos possibilitam a preparação em uma só visita e tem baixo custo. 
Ressaltaram também a necessidade de resultados esteticamente satisfatórios, já que houve o aumento da utilização da coroa de porcelana pura. O pino de cerâmica de zircônia oferece uma base estética para uma coroa totalmente cerâmica.

McLEAN et al. ${ }^{92} 1998$, apresentou critérios para que o clínico pudesse identificar dentes tratados endodonticamente que pudessem ser restaurados com um alto nível de previsibilidade, fornecendo uma visão baseada em evidências científicas. Ele sugere para que um dente tratado endodonticamente não necessite de um pino intra-radicular o dente possua 2,0 $\mathrm{mm}$ de férula dentinária efetiva para reter a prótese e ainda que dentes tratados endodonticamente deveriam ser evitados como pilares suportados por encaixes de precisão, extensão distal ou cant laver.

Estudando a resistência à fratura de 2 tipos de restaurações: dentes restaurados com pinos de carbono pré-fabricados e núcleo de compósito e dentes restaurados com núcleos fundidos MARTINEZ-INSUA ${ }^{88}$, em 1998, mostraram que o limiar de fratura média foi de $103.7 \mathrm{~kg}$ para o grupo (I) e 207.7kg para grupo (II). No grupo II, entretanto, a fratura quase sempre afetou o próprio dente, enquanto no grupo I, o conjunto pino/núcleo quase sempre falhou primeiro. Os autores concluíram que o limiar de fratura significativamente mais alto foi registrado para o grupo de pino e núcleo fundido. Dentes restaurados com pinos fundidos tipicamente mostraram fratura do dente, embora em cargas que raramente ocorrem clinicamente. Os autores ainda concluem que pinos e núcleos usados para a restauração 
de dentes despolpados deveriam ser fortes, embora o pino deveria falhar antes da estrutura dentária remanescente em resposta para estresse mecânico. Neste estudo, o limiar de falha de pinos de fibra de carbono foi significativamente mais baixo do que o limiar para pinos fundidos. Pinos fundidos comumente resultaram em fratura dentária.

REAGAN et al. ${ }^{115}$, em 1999, avaliou a resistência à fadiga de três tipos de núcleos sem a utilização de coroa protética. No primeiro grupo utilizaram dois pinos pré-fabricados com núcleo de amálgama; no segundo grupo, os mesmos pinos pré-fabricados com núcleo de resina composta; e no terceiro núcleos metálicos fundidos como controle. Depois de submetidos a testes de fadiga até a ocorrência de fratura o grupo restaurado com núcleo de compósito apresentou valores superiores aos dos outros grupos, isto se atribui ao fato da resina composta ter baixo módulo de elasticidade que permite uma melhor absorção dos impactos durante o teste de fadiga mecânica.

SIRIMAI et al. ${ }^{132}$, em 1999, avaliaram a resistência à fratura vertical de 60 incisivos centrais tratados endodonticamente e restaurados com seis diferentes métodos de pinos e núcleos protéticos. Os sistemas escolhidos foram: núcleos metálicos fundidos cimentados com fosfato de zinco; pinos pré-fabricados metálicos cimentados passivamente com fosfato de zinco e núcleo em resina; fibras de polietileno fixadas com cimento resinoso e envoltas por núcleo em resina; pino pré-fabricado metálico passivo e núcleo confeccionado com fitas de polietileno e resina; pinos pré-fabricados 
metálicos passivos fixados com cimento resinoso e núcleo em resina. Utilizou-se uma velocidade de $0,5 \mathrm{~mm} / \mathrm{min}$ num ângulo de $130^{\circ}$ para a realização do teste de resistência a compressão. Concluiu-se que a adição de fibras de polietileno a um núcleo pré-fabricado resulta em menor quantidade de fraturas no sentido vertical se comparado a núcleos metálicos fundidos. Mas, os núcleos metálicos fundidos são os que apresentam maior resistência à fratura entre os núcleos estudados.

STOCKTON ${ }^{147}$, em 1999, publicou uma revisão de literatura estabelecendo alguns critérios que podem ser seguidos na restauração de dentes tratados endodonticamente com o objetivo de otimizar a retenção e diminuir o risco de fratura. Ele sugere que o primeiro passo é o diagnóstico radiográfico detalhado da raiz para o sucesso do tratamento. A estrutura dental deve ser conservada ao máximo, levando em consideração que canais amplos são mais propensos à fratura se comparados a fraturas provocadas pelos diversos modelos de pinos. Com relação aos pinos, itens como comprimento, diâmetro, desenho do núcleo devem ser escolhidos conforme a necessidade do paciente. O autor enfatiza que a técnica de cimentação é que deve ser levada em consideração, porque os cimentos geralmente apresentam o mesmo padrão de comportamento. Aconselha que cada situação deve ser analisada de acordo com a necessidade de cada caso.

ISIDOR; BRONDUM; RAVNHOLT ${ }^{66}$, em 1999, realizaram um estudo sobre o efeito do comprimento dos pinos pré-fabricados e do compri- 
mento da férula na resistência à fadiga de dentes bovinos restaurados através de coroas metálicas. Utilizaram 90 raízes que foram incluídas e fixadas em blocos de resina acrílica. Cada raiz permaneceu com $5 \mathrm{~mm}$ de estrutura acima do ponto de inclusão em acrílico. Os pinos pré-fabricados foram dmentados no canal radicular com cimento de fosfato de zinco. Foram construídos núcleos de preenchimento (Gluma/ Bayer e Concise/3M) sobre pinos metálicos com comprimentos de $5 \mathrm{~mm}, 7,5 \mathrm{~mm}$ e $10 \mathrm{~mm}$. A quantidade de estrutura dental envolvida no preparo para fornecer o efeito de abraçamento variou em comprimentos de $0 \mathrm{~mm}, 1,25 \mathrm{~mm}$ e 2,5 mm. Os preparos confeccionados foram de tipo chanfrado. As coroas foram enceradas diretamente sobre as amostras e incluídas para fundição em liga nobre (Au). Posteriormente as coroas metálicas foram cimentadas com fosfato de zinco. O teste de resistência à fadiga foi conduzido a 1 ciclo por segundo, com carga de

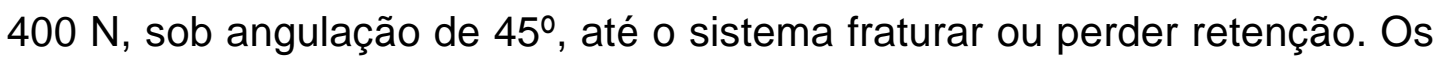
autores puderam concluir que o comprimento do pino não teve correlação estatística com a resistência à fadiga, porém, o comprimento da férrula mostrou correlação positiva ao nível de $1 \%$ de probabilidade. Na sua discussão, citam que a literatura ainda não esclareceu a real influência dos pinos e núcleos na longevidade de dentes restaurados com coroas protéticas. A influência do pino na resistência desses dentes pode ser suplantada pelo abraçamento da coroa sobre a dentina coronária - efeito de abraçamento. Os autores comentam que, semelhante ao dente humano, os dentes bovinos sofrem alterações de resistência devido à idade. Além disso, as dimensões das raízes podem ter influência nos valores de resistência à fratura, sendo 
importante a padronização do tamanho, forma e idade dos dentes. Baseados em outro estudo, comentam que dentes bovinos e humanos apresentam resistência à tração e módulo de elasticidade semelhantes, viabilizando o seu emprego como alternativa aos dentes humanos.

Uma ampla revisão de literatura foi realizada por MORGANO e BRACKETT $^{99}$, em 1999, com o objetivo de estudar fatores relacionados a restauração de dentes tratados endodonticamente, entre os mais destacados para o sucesso destas restaurações foram os cimentos utilizados. Destacam como desvantagem dos núcleos metálicos fundidos o fato de necessitarem duas visitas ao consultório e que materiais restauradores devem suportar o estresse induzido por forças mastigatórias. Outros fatores tais como a quantidade de tecido dental residual, tempo de consulta clínica, facilidade de manipulação, devem ser considerados qua ndo estamos selecionando o sistema de pinos intra-radiculares / núcleo de preenchimento. Considerações econômicas também podem afetar a escolha de uma técnica. Os autores verificaram que o percentual de uso de pinos pré-fabricados tem se tornado muito popular entre os dentistas dos Estados Unidos, constataram que $40 \%$ dos clínicos gerais utilizam pinos pré-fabricados na maioria das vezes, e que os mais usados são os pinos pré-fabricados serrilhados. Ainda que o uso de pinos pré-fabricados aliados a uma reconstrução de núcleo de preenchimento é geralmente tido como um método restaurador de escolha para molares desvitalizados com perda excessiva de substância dental. 
EM 2000, CARDOSO; POSKUS ${ }^{23}$ avaliaram a dureza Vickers de resinas compostas condensáveis. Estudaram 5 resinas compostas, 3 condensáveis (Alert, Solitaire e Surefil), 1 híbrida tradicional (Z-100) e 1 de micropartículas (Silux) utilizadas com 2 sistemas adesivos (Bond 1 e Etch Prime 3.0) restaurando cavidades pela técnica de inserção "incremental" ou única. Cavidades proximais padronizadas, em 100 dentes pré-molares extraídos, foram confeccionadas e os dentes restaurados com os materiais citados, divididos em grupos de acordo com a resina, o sistema adesivo e a técnica de inserção utilizada. Os espécimes sofreram ciclagem térmica de 700 ciclos, variando a temperatura de 5 a $55^{\circ} \mathrm{C}$ por 60 segundos em cada banho. Os dentes foram preparados para que a dureza Vickers fosse determinada na superfície oclusal e na cervical de cada restauração. Concluíram que a técnica de inserção incremental proporciona maior dureza da resina na região cervical que a técnica da inserção única, não havendo diferença entre ambas as técnicas na dureza da superfície oclusal. Dentre as resinas houve similaridade entre a Z-100 e Alert, as melhores, seguidas pela Surefil com valores intermediários e tendo Solitaire e Silux os piores resultados.

GEGAUFF $^{46}$, em 2000, analisou o efeito do aumento de coroas e presença de férulas em pré-molares artificiais. $O$ autor utilizou 20 espécimes os quais foram divididos em 2 grupos, 10 apresentando aumento de coroas e férula de $2 \mathrm{~mm}$ e 10 com o término cervical na junção cemento esmalte. Foram confeccionados para todos os dentes núcleos metálicos em liga de ouro e coroas metálicas fundidas cimentadas com fosfato de zinco. Metade 
dos espécimes de cada grupo recebeu aplicação de forças sobre a cúspide lingual enquanto a outra metade sobre a crista marginal. Os dentes artificiais foram levados aos testes de compressão e os resultados mostraram que os espécimes que não apresentavam aumento de coroa e presença de férulas resistiram significativamente mais às forças aplicadas em ambas situações.

BARATIERI $^{12}$, em 2000, realizou um estudo avaliando se o preparo conservativo para coroas venner localizado somente em esmalte melhoraria a resistência à fratura de incisivos centrais superiores e se a presença de pinos intra-radiculares aumentaria a resistência à fratura destes dentes tratados endodonticamente. Foram utilizados 50 incisivos centrais superiores divididos em 9 grupos, um controle e 8 experimentais, variando-se a presença ou não de pino intra-radicular, a localização em esmalte ou dentina do preparo dentário e a presença ou não de coroas venners. Todos os espécimes foram levados à máquina de ensaios universal para os testes de compressão. Os resultados mostraram que a localização do preparo não interferiu significativamente na resistência do dente apesar dos preparos em esmalte apresentarem valores médios de força maiores que os em dentina. Em relação aos pinos intra-radiculares o autor concluiu, que a presença deste não aumentou a resistência à fratura dos dentes tratados endodonticamente.

Uma revisão de literatura sobre os fatores que afetam a fratura de dentes reconstruídos com pinos e núcleos foi realizado por FERNANDES ${ }^{42}$ em 2001. Analisando os artigos estudados o autor chegou a conclusão que 
os principais são: comprimento, diâmetro e material do pino bem como os materiais dos núcleos de preenchimento, além da adaptabilidade do pino, desenho e cimento utilizado. A literatura mostra que para conseguir uma longevidade do dente restaurado é necessário que haja preservação de estrutura dentária. Não se deve utilizar pinos com o intuito de reforçar dentes, por outro lado, deve-se fazer uma cuidadosa avaliação das forças funcionais e para funcionais. Além disso ele sugeriu que a escolha do material de preenchimento e suas características de distribuição de estresse devem ser consideradas pelo clínico. Os núcleos de amálgama e resinas compostas têm sido relatados ajudar na distribuição desse estresse.

HENRY ${ }^{56}$, em 2001, procurou verificar o efeito combinado e individual do tratamento endodôntico e restauração com coroas venners de incisivos centrais superiores. Para isto foram selecionados 40 espécimes divididos em 4 grupos de 10 cada, o grupo I foi composto por dentes intactos, o grupo II por dentes tratados endodonticamente, o grupo III restaurados por coroas venner e o grupo IV tratados endodonticamente e restaurados com coroas venners. Todos os espécimes foram levados à máquina de ensaios universal para os testes de compressão, realizados à uma angulação de $30^{\circ}$. As médias encontradas foram 415 N, 370 N, 420 N e 448 N para os grupos I, II, III, IV respectivamente. Analisando os resultados o autor chegou à conclusão que os dentes tratados endodonticamente são capazes de suportar a mesma magnitude de forças oblíquas que um dente intacto e que o tratamento endodôntico, a restauração com coroas venners e a combinação 
entre eles não foi capaz de afetar o modo de falhas dos incisivos centrais superiores.

PAULILLO $^{104}$, em 2001, avaliou diferentes sistemas de retenção intraradiculares associados a núcleo de preenchimento e coroa metálica sobre término em ombro sem abraçamento cervical. Os resultados demonstraram valores superiores para o núcleo metálico fundido, sem diferença estatística para pinos pré-fabricados metálicos. O autor utilizou em seu experimento liga de níquetcromo para confecção dos núcleos fundidos e pinos préfabricados de aço inoxidável, Flexi-post. Comparou também pino não metálico, passivo, de fibra de vidro, que apresentou os menores valores de resistência à fratura, com diferença estatística aos anteriores. O autor comenta que, com término em ombro reto, os esforços são transmitidos diretamente ao núcleo causando efeito de alavanca sobre a raiz.

SORENSEN et al. ${ }^{140}$, em 2001 , estudou critérios de seleção para pinos e núcleos na restauração de dentes tratados endodonticamente avaliando às propriedades físicas dos materiais de preenchimento, forças de inclinação de pinos pré-fabricados, e retenção de materiais de preenchimento para pinos de zircônia. O autor concluiu que quando houver menos da metade do remanescente dentário coronal um pino ou núcleo deve ser indicado. O autor ainda mostrou diferenças estatisticamente significativas entre os materiais dos núcleos de preenchimentos, os quais foram testados em relação a sua força flexural, tendo a resina composta apresentado os melhores resultados. Além disso mostrou que o pino pré- 
fabricado de aço inoxidável foi significantemente mais resistente que os outros sistemas de pinos.

Em 2001, ECKERBOM; MAGNUSSON ${ }^{39}$, entrevistou 892 cirurgiões dentistas clínicos gerais e 150 protesistas suecos, investigando quais eram suas opiniões atuais sobre como restaurar um dente tratado endodonticamente. Para isto um questionário contendo 31 questões foi distribuído entre eles. Vinte e nove por cento dos dentistas entrevistados e 17\% dos protesistas são de opinião de que pinos intra-radiculares reforçam dentes tratados endodonticamente. A grande maioria dos profissionais suecos utiliza núcleos metálicos fundidos apesar do grande sucesso dos pinos pré-fabricados.

RAYGOT $^{114}$, em 2001, analisou a resistência e modo de fratura de incisivos tratados endodonticamente restaurados com núcleo metálico fundido, pinos de aço-inoxidável e pinos de carbono. Selecionourse 30 incisivos humanos os quais foram divididos em 3 grupos de 10 cada, um para cada tipo de pino. Após a cimentação dos pinos e das coroas, todos os espécimes foram levados à máquina de ensaios universal para realização dos testes de compressão a 130․ Os resultados não encontraram diferença estatisticamente significativa entre os grupos estudados. $O$ autor ainda observou que 70 a $80 \%$ de todos os dentes apresentavam fratura acima do nível ósseo possibilitando assim o reparo.

PILO et al. ${ }^{110}$, em 2002, avaliou a espessura dentinária residual de pré-molares inferiores depois do preparo do canal para a colocação de pinos 
intra-radiculares com brocas Gates glidden e Para-post. O autor comenta que dentes tratados endodonticamente comumente requerem uso de pinos de estabilização corono-radicular e que a principal razão para este pino é reter o núcleo que substituí a porção coronal ausente e fornecer retenção para uma restauração definitiva. Relata ainda que as pesquisas têm confirmado que pinos não reforçam dentes, mas possuem o potencial de enfraquecê-los. O autor enfatiza que a técnica mais segura para a remoção de guta percha tem sido o uso de um instrumento aquecido, porém a mais comum e mais rápida é a dos instrumentos rotatórios. Este procedimento é tradicionalmente realizado através de brocas de Gates glidden, Brocas de Peeso, Instrumentos gPX, ou com brocas fornecidas em vários kits de pinos. As brocas gates glidden não possuem ponta ativa e são consideradas mais seguras e previsíveis para preparo do conduto. O autor utilizou 12 pré-molares inferiores unirradiculares os quais foram incluídos em resina acrílica autopolimerizável até a junção cemento/esmalte (CEJ). Três secções horizontais foram feitas, 1, 3 e 5mm em direção ao ápice, após o preparo do conduto com limas número 40 e posteriormente com brocas gattes gliden, os eixos mesio-distal e vestíbulo-lingual do dente foram cuidadosamente marcados e a dentina residual foi medida para cada fatia. Concluiu-se que a espessura dentinária média de $5 \mathrm{~mm}$ abaixo da CEJ nas direções mesial e distal após o preparo do espaço do pino aproximou ao mínimo aceito de $1 \mathrm{~mm}$, afirmando que um preparo conservador deve ser feito pois este seria 0 principal fator que determina 0 prognóstico de dentes tratados endodonticamente e restaurados proteticamente. 
SANTOS; SILVA E SOUZA JR; MONDELLI ${ }^{123}$ realizaram uma revisão de literatura em 2002, na qual citam que a contração de polimerização é um dos fatores que mais contribui para o insucesso das resinas compostas e que ela é o resultado da movimentação e aproximação dos monômeros entre si durante a formação da cadeia polimérica. Afirmaram que quanto maior for o grau de conversão do monômero, maior será a contração de polimerização, e que, nas resinas atuais, o grau de conversão fica em torno de 60 a $70 \%$ e a contração de polimerização foi reduzida para 1,5 a $3 \%$. Relataram que a contração de polimerização é inerente às resinas compostas e irá persistir até que resinas sem contração ou portadoras de monômeros que se expandam durante a reação de polimerização estejam disponíveis. Concluíram que inúmeros fatores são responsáveis pelo estresse gerado na contração de polimerização, tais como módulo de elasticidade, composição da resina composta, fator de configuração da cavidade e intensidade de luz emitida pelo aparelho fotopolimerizador. Indicaram, como formas de minimizar esta contração, o uso de intensidades mais baixas de luz, com o intuito de prolongar a fase pré-gel, e o uso da técnica incremental.

HEYDECKE et al. ${ }^{57}$, em 2002, realizou uma revisão de literatura para comparar a performance clínica e in vitro de núcleos fundidos e núcleos de preenchimento com pinos pré-fabricados em dentes unirradiculares. A comparação das cargas de fratura nos estudos in vitro não revelaram diferenças estatisticamente significativas entre as duas modalidades de tratamento. A taxa de sucesso para núcleos fundidos em dois estudos teve 
média de $87,5 \%$ em um terceiro estudo alcançou 86,4\% para núcleos de preenchimento após 72 meses.

Em 2002, AKKAYAN ${ }^{3}$, analisou o efeito de 4 sistemas de pinos intraradiculares sobre a resistência a fratura de dentes tratados endodonticamente. Foram selecionados 40 caninos superiores divididos em 4 grupos de 10 cada, restaurados com pinos de titânio (grupo 1), fibras de quartzo (grupo 2), fibra de vidro (grupo 3) e zircônia (grupo 4). Após a cimentação dos pinos e das coroas os dentes foram encaminhados à máquina de ensaios universal para testes de compressão a $130^{\circ}$ ao longo eixo do dente. Os resultados encontrados foram $66,95 \mathrm{~kg}, 91,20 \mathrm{~kg}, 75,90 \mathrm{~kg}$, $76,91 \mathrm{~kg}$ para os grupos 1 a 4 respectivamente. O grupo 2 apresentou resistências significativamente maiores que os outros três grupos. Os grupos 3 e 4 foram estatisticamente similares. O autor observou ainda que as fraturas ocasionadas no grupo 2 e 3 eram totalmente reparáveis enquanto fraturas irreparáveis ocorreram nos grupos 1 e 4 .

Em 2002, PIERRISNARD ${ }^{109}$, analisou através de um estudo de elemento finito o efeito de diferentes reconstruções corono-radiculares na transmissão do estresse para os tecidos dentais. $O$ modelo gerado em computador foi planejado para comparar os parâmetros mecânicos de diferentes graus de perda tecidual coronal e restauração com diferentes materiais. Os dois níveis de perda tecidual foram: Perda total da dentina coronal e perda parcial com $2 \mathrm{~mm}$ de estrutura dentinária saudável (presença de férula). As técnicas restauradoras foram: núcleo metálico fundido de $\mathrm{NiCr}$; 
pino de NiCr e núcleo de compósito; pino de fibra de carbono e núcleo de compósito; e restauração de compósito sem pino. Os resultados mostraram que os maiores estresses foram encontrados na região cervical. Na ausência de férula áreas de alta intensidade de estresse foram observadas. Quando havia a presença de um pino intra-radicular as forças eram menos intensas. Os autores concluíram que a ausência de férula foi o fator de maior contribuição para aumentar o risco de fratura do dente e que, diferentemente de muitos outros trabalhos, a presença de um pino intra-radicular aumenta a resistência do dente tratado endodonticamente. 
3 PROPOSIÇÃO 


\section{PROPOSIÇÃO}

3.1. Avaliar a influência da quantidade de remanescente dentário coronal sobre a resistência de dentes tratados endodonticamente restaurados com pinos intra-radiculares;

3.2. Verificar se a utilização de pinos intra-radiculares reforça dentes tratados endodonticamente;

3.3. Analisar o padrão de fratura encontrado em dentes tratados endodonticamente restaurados com pinos pré-fabricados e resina composta variando a quantidade de remanescente coronal, núcleos metálicos fundidos e sem a utilização de um pino intra-radicular. 
4 MATERIAL E MÉTODOS 


\section{MATERIAL E MÉTODOS}

\subsection{MATERIAL}

Para a realização deste trabalho foram utilizados os materiais descritos na tabela 1.

TABELA 1: Material de consumo utilizado

\begin{tabular}{|c|c|c|}
\hline Material & Nome Comercial & Fabricante \\
\hline $\begin{array}{l}\text { Resina Acrílica auto } \\
\text { polimerizável }\end{array}$ & Jet & $\begin{array}{l}\text { Artigos Odontológicos Clássicos } \\
\text { LTDA, São Paulo-SP, Brasil Lote: } \\
991063\end{array}$ \\
\hline Pino pré-fabricado & Euro-Post & $\begin{array}{l}\text { Anthogyr S.A., Sallanches- França } \\
\text { Lote: } 01062702\end{array}$ \\
\hline Ácido Fosfórico & Magic Acid & $\begin{array}{l}\text { Vigodent S/A Industria e Comércio, } \\
\text { Rio de Janeiro-RJ, Brasil Lote: } 00800\end{array}$ \\
\hline Sistema Adesivo & Prisme e Bond 2.1 & $\begin{array}{l}\text { Dentsply Ind e Com. Petrópolis-RJ, } \\
\text { Brasil Lote: } 39013\end{array}$ \\
\hline $\begin{array}{l}\text { Liga Metálica (Núcleo } \\
\text { Fundido) }\end{array}$ & $N P G^{T M}$ & AalbaDent, Cordelio-CA, USA \\
\hline Agente Cimentante & $\begin{array}{l}\text { RelyX } \\
\text { lonômero de Vidro }\end{array}$ & $\begin{array}{l}\text { 3M Dental Products División St.Paul- } \\
\text { Minisota, USA Lote: } 3515 \text { I (Líquido); } \\
\text { 3515p (Pó) }\end{array}$ \\
\hline $\begin{array}{l}\text { Resina Composta } \\
\text { Fotopolimerizável }\end{array}$ & Z-100 & $\begin{array}{l}3 \text { M Dental Products División St.Paul- } \\
\text { Minisota, USA Lote: } 9 \mathrm{HF}\end{array}$ \\
\hline
\end{tabular}

Os demais instrumentos e dispositivos utilizados encontram-se disponíveis nos laboratórios de pesquisas do Departamento de Prótese da FOB-USP. 


\subsection{MÉTODO}

Este estudo procurou avaliar a influência da variação do remanescente dentário coronal em quatro alturas: $0 \mathrm{~mm}, 1 \mathrm{~mm}, 2 \mathrm{~mm}$ e $3 \mathrm{~mm}$ comparado aos grupos controles que apresentaram dentes restaurados com núcleo metálico fundido e dentes sem nenhum tipo de retenção intraradicular. Todos os preparos receberam término gengival em ombro. Os pinos pré-fabricados em aço inoxidável, paralelos de extremidade cônica, rosqueáveis, foram utilizados de maneira passiva associados aos núcleos de preenchimento em resina composta fotopolimerizável (Z-100). A variável de resposta foi a resistência à fratura, verificada em unidades experimentais compostas por dentes caninos superiores humanos tratados endodonticamente. Para cada condição em teste foram utilizadas dez raízes, perfazendo um total de 60 amostras.

\subsubsection{Seleção dos Dentes, Limpeza e Armazenamento}

Para a realização deste trabalho foram selecionados 60 caninos humanos coletados de clínicas odontológicas, com anatomia e dimensões aproximadamente semelhantes cujo comprimento radicular variasse entre 15 e $18 \mathrm{~mm}$. Os dentes foram devidamente mantidos em solução fisiológica à temperatura ambiente durante todo o período do estudo de acordo com as 
normas exigidas pelo Comitê de Ética da Faculdade de Odontologia de Bauru-USP.

\subsubsection{Tratamento Endodôntico}

A terapia endodôntica iniciou-se com as aberturas das câmaras coronárias realizadas através de uma ponta diamantada esférica número 1012 (KG Sorensen) em alta rotação e a forma de contorno feita com uma ponta diamantada tronco-cônica de ponta inativa número 2082 (KG Sorensen). A broca de Batt (Dyna-gS Brasil Com. Imp. Ltda) em baixa rotação permitiu o término da forma de conveniência.

Após a abertura coronária, realizourse a odontometria com limas tipo K-file (Maillefer) de $31 \mathrm{~mm}$, a $1 \mathrm{~mm}$ do ápice. O canal radicular de cada dente foi instrumentado de acordo com a técnica escalonada regressiva com uma lima 35 pela International Standardization Organization (ISO) na constrição apical, os canais irrigados com solução de hipoclorito $(2,5 \%)$ durante toda a instrumentação e secos com pontas de papel absorvente (Tanari, Tamariman Industrial LTDA, Macaçaruru-AM).

Os condutos foram obturados através da técnica da condensação lateral utilizando-se um cone de gutta-percha principal (Tamari, Tamariman $\mathbf{h}$ dustrial LTDA, Macaçaruru-AM) número $35 \mathrm{ISO}^{42}$, três cones secundários (Tamari, Tamariman Industrial LTDA, Macaçaruru-AM) e cimento Endometa- 
sone Ivory (Specialites Septodont - França).

\subsubsection{Distribuição dos Grupos}

Após a seleção da amostra, os 60 dentes foram aleatoriamente divididos em seis grupos de dez cada um e submetidos a diferentes tipos de procedimentos conforme o grupo que pertenciam.

GRUPO I - Dentes tratados endodonticamente restaurados com resina composta somente na embocadura do canal sem a utilização de um retentor intra-radicular.

GRUPO II - Dentes sem remanescente coronal, restaurados com núcleos metálicos fundidos.

GRUPO III - Dentes sem remanescente coronal, restaurados com pinos préfabricados e resina composta.

GRUPO IV - Dentes com $1 \mathrm{~mm}$ de remanescente coronal, restaurados com pinos pré-fabricados e resina composta.

GRUPO V - Dentes com $2 \mathrm{~mm}$ de remanescente coronal, restaurados com pinos pré-fabricados e resina composta.

GRUPO VI - Dentes com 3mm de remanescente coronal, restaurados com pinos pré-fabricados e resina composta. 


\subsubsection{Preparo dos Dentes}

4.2.4.1 Grupo I sem pino intra-radicular.

Todos os dentes foram preparados de acordo com a técnica descrita por PEGORARO et al. ${ }^{105}$. Seis milímetros foi a altura de dentina coronária padronizada para todos os preparos.

4.2.4.1 Grupos II e III sem remanescente coronal.

Os dentes foram inicialmente demarcados com grafite seguindo a linha cemento-esmalte, tendo, posteriormente, suas coroas seccionadas com a utilização de um disco de carburundun (Figura 1).
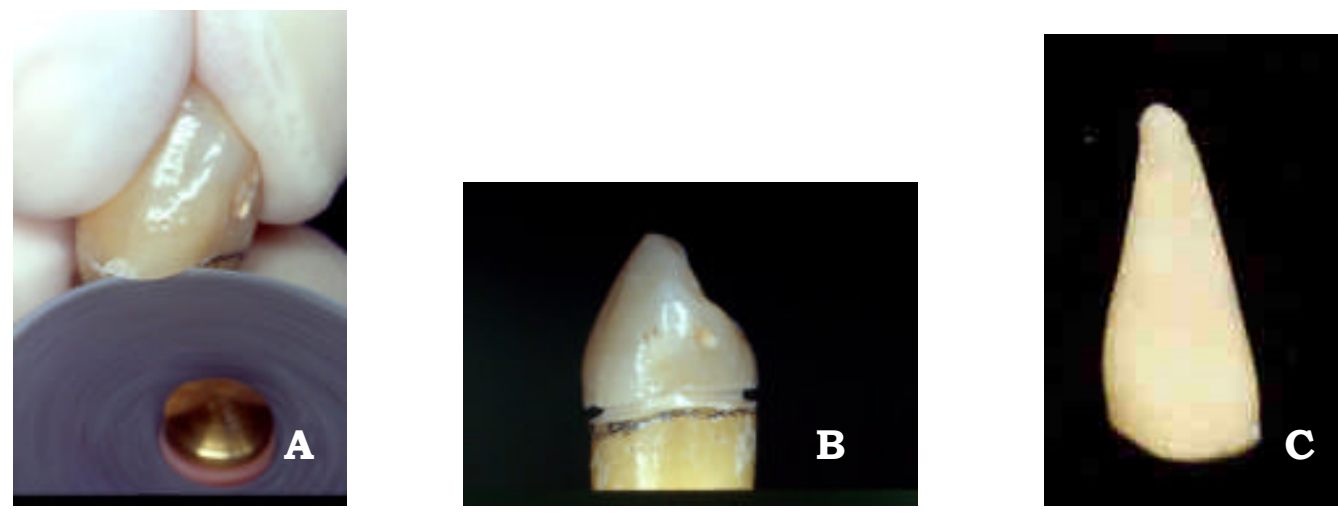

FIGURA 1: Preparos dos dentes sem remanescente coronário
A- Corte da coroa com disco de carburundun
B- Delimitação da linha cemento-esmalte
C- Dente sem remanescente coronal 
4.2.4.2 Grupos IV, V e VI - com remanescente coronal

Para que fosse possível a padronização dos preparos, todos os dentes foram preparados seguindo a junção amelocementária. Os remanescentes dentários coronais de $1 \mathrm{~mm}, 2 \mathrm{~mm}$ e $3 \mathrm{~mm}$ foram demarcadas através de um espessímetro Wilcos (Wilcos -Brasil). A partir deste ponto, os dentes foram preparados, respeitando as alturas delimitadas (Figura 2), com uma broca diamantada número 1051 (Kg Sorensen) em alta rotação, com refrigeração, permitindo a realização de um término cervical em ombro reto e, ainda, uma padronização da espessura da dentina coronária entre a parte interna e externa do canal de no mínimo $1,5 \mathrm{~mm}$.
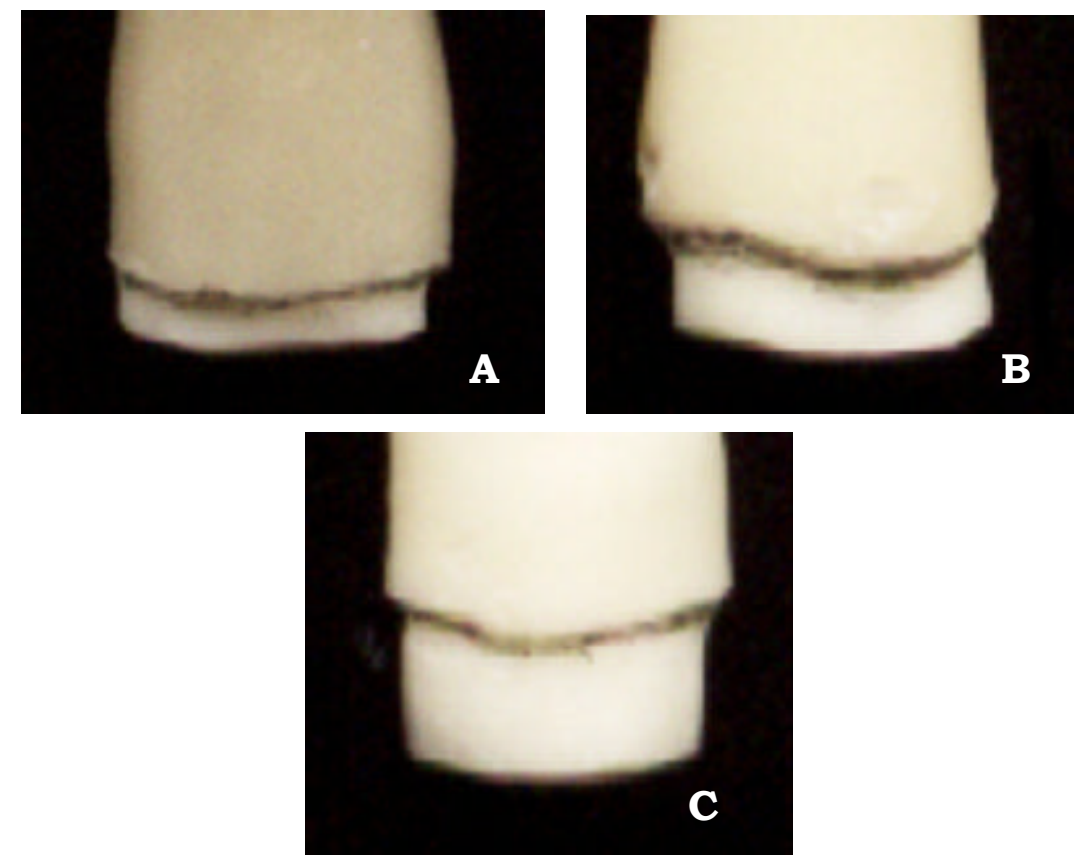

FIGURA 2: Preparo dos dentes com remanescente coronal com 1, 2 e 3mm
A- $1 \mathrm{~mm}$
B- $2 \mathrm{~mm}$
C- $3 \mathrm{~mm}$ 


\subsection{PREPARO DOS CONDUTOS}

\subsubsection{Grupo I (sem pino intra-radicular)}

Após a obturação do conduto a guta-percha foi removida somente da embocadura do canal radicular, o qual foi restaurado com resina composta Z-100 (3M Dental Products Division St. Paul - Minisota, USA). Não foram utilizados retentores intra-radiculares para este grupo.

4.3.2. Grupo II (núcleo metálico fundido) e Grupos III, IV, V e VI (pinos pré-fabricados)

Para a remoção da guta-percha foram utilizadas pontas Rhein (Duflex) com cursores graduados em 9mm, em baixa rotação, mantendo-se no mínimo $5 \mathrm{~mm}$ de material obturador remanescente no ápice.

Selecionou-se o pino número 5317 , de $13 \mathrm{~mm}$ de comprimento do sistema de pinos intra-radiculares Euro-Post (Anthogyr S.A., SallanchesFrança), cuja broca correspondente foi inserida no canal radicular procurando-se padronizar o diâmetro do conduto e inclinação das paredes para todos os grupos, inclusive para o grupo II. Todos os pinos 
apresentaram-se com $4 \mathrm{~mm}$ de seu comprimento acima da junção cemento/esmalte.

\subsection{OBTENÇÃO DOS NÚCLEOS METÁLICOS FUNDIDOS}

\subsubsection{Obtenção das matrizes de Acetato}

Para que fosse possível a padronização das dimensões dos núcleos metálicos fundidos e de preenchimento foi confeccionado um padrão metálico de Cu-Al (Goldent - AJE Comércio Importação e Exportação Ltda) obtido através da fundição de um modelo de resina acrílica autopolimerizável. Este era uma cópia exata da porção coronária e radicular de dentes de amostras piloto moldados com silicona de adição (Express $3 \mathrm{M})$.

Após a obtenção do padrão metálico, os mesmos foram levados a uma máquina plastificadora à vácuo (Bioart) onde foram eproduzidas 60 matrizes de acetato, que serviram para auxiliar na confecção dos núcleos metálicos fundidos e na reconstrução da porção coronária em resina composta (Figura 3). 

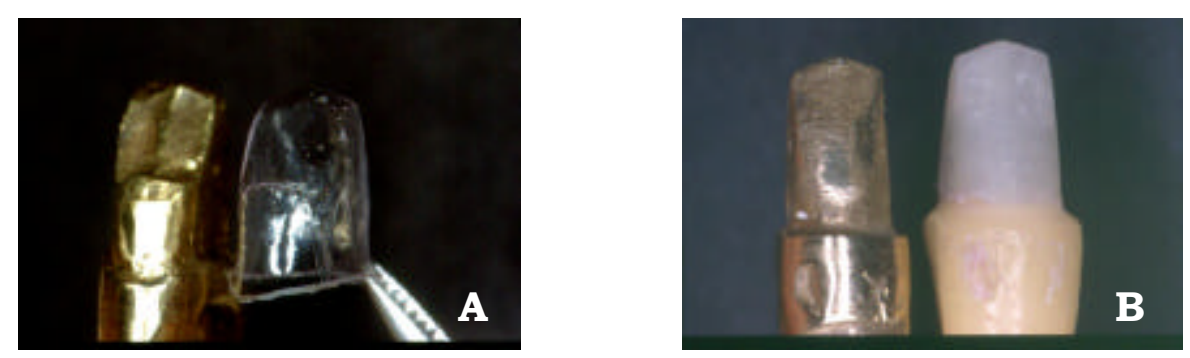

FIGURA 3: Confecção das matrizes de polietileno

A) Matriz de acetato

B) Núcleo de preenchimento obtido através da matriz de acetato

\subsubsection{Obtenção da porção radicular e coronária do núcleo} metálico fundido

Os núcleos metálicos fundidos foram obtidos a partir de moldagens dos condutos com resina acrílica ativada quimicamente Duralay (Reliance Dental Mfg. Co. Chicago, USA) de acordo com PEGORARO et al. ${ }^{105}$ Após a moldagem do conduto preencheurse, com a mesma resina, a matriz de acetato colocando-a sobre o dente visando a confecção da parte coronária do núcleo similar à aquela confeccionada para os núcleos de preenchimento.

Após esta etapa os padrões de resina foram encaminhados para fundição. Para que isto fosse possível confeccionaram-se condutos de alimentação com fio de cera número 3 , sobre a porção coronária.

Os padrões foram cuidadosamente removidos e fixados à base formadora de cadinho pelo vértice dos condutos de alimentação, sobre o 
qual era adaptado um anel metálico para fundição revestido de amianto e umedecido em água.

A inclusão dos padrões foi feita com revestimento "Cristobalite" para Incrustações (Kr Mfg. Co., Michigan, USA), numa relação água/pó de 0,40 utilizando-se um espatulador e inclusor mecânico (Polidental Indústria Brasileira, SP - Brasil). A expansão do revestimento foi feita pela técnica convencional da expansão térmica, empregando-se uma liga de cobre/alumínio para fundição (NPG ${ }^{\mathrm{tm}}$, AalbaDent, Cordelio-CA, USA) (Figura 4).

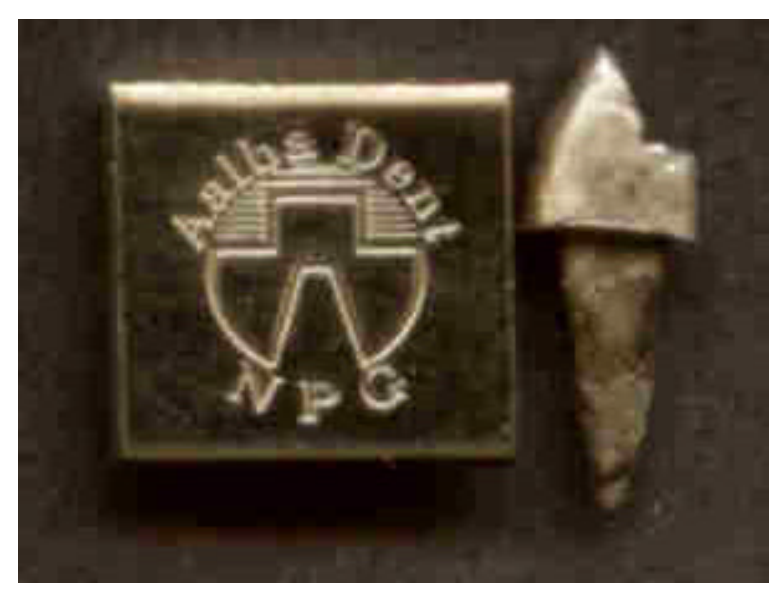

FIGURA 4: Núcleo metálico fundido e liga de cobre/alumínio

Depois de fundidos os núcleos foram lavados e escovados em água corrente e liberados do conduto de alimentação com um disco de carborundum e feito um exame minucioso com auxílio de uma lupa de quatro aumentos (Lactona - Produtos Dewsin). Somente foram utilizados os núcleos considerados como clinicamente aceitáveis. Isto significou um assentamento completo no canal preparado e adaptação à base cervical, testados também com lupa e sonda exploradora no 5 (Duflex - S.S.White 
Artigos Dentários S/A, São Paulo - Brasil).

\subsection{CIMENTAÇÃO DOS PINOS PRÉ-FABRICADOS E NÚCLEOS METÁLICOS FUNDIDOS}

Antes da cimentação dos pinos, os condutos foram devidamente limpos e secos. Todos os pinos pré-fabricados e núcleos metálicos fundidos foram cimentados com cimento de ionômero de vidro (Rely X, 3M Dental Products División St.Paul-Minisota, USA) de acordo com as recomendações do fabricante. Completada a mistura, o cimento foi levado ao interior do conduto por uma broca Lentulo e aplicado no pino através de um pincel n.2 68,145 (Figura 5), após isto, este foi assentado passivamente no canal e mantido sob uma pressão de $5 \mathrm{~kg}$ durante $10 \mathrm{~min}$. Passado o tempo de presa do cimento os dentes restaurados com núcleo metálico fundido foram encaminhados novamente para o soro fisiológico, enquanto os que foram com pinos pré-fabricados foram encaminhados para a confecção dos núcleos de preenchimento. 

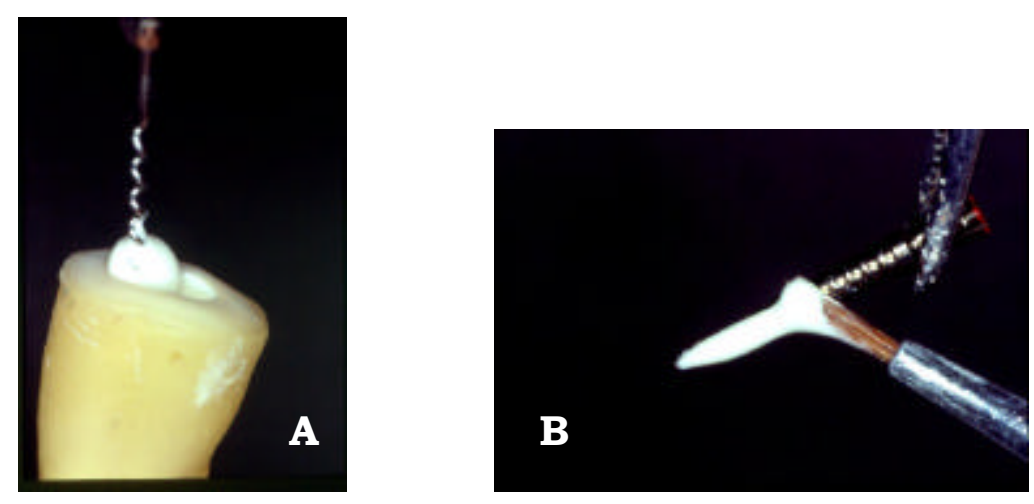

FIGURA 5: Cimentação dos pinos intra-radiculares
A- Colocação do cimento no canal radicular
B- Utilização do pincel para colocação do cimento no pino-pré-fabricado

\section{6 CONFECÇÃO DOS NÚCLEOS DE PREENCHIMENTO.}

A estrutura dental coronária dos espécimes dos grupos III, IV, V e VI foi condicionada com ácido fosfórico a 37\% por 15 segundos, lavada com jatos de água por 20 segundos e seca com papel absorvente. Sobre a dentina úmida foi aplicada uma camada do sistema adesivo Primer-Bond 2.1, espalhada por jatos de ar durante cinco segundos seguindo-se de fotoativação por 20 segundos $^{6}$ através do aparelho de fotopolimerização Ultra lux (Dabi Atlante).

A resina composta foi inicialmente adaptada em torno do pino préfabricado em incrementos de aproximadamente $2 \mathrm{~mm}$ de espessura ${ }^{121} \mathrm{e}$ fotoativados durante 20 segundos cada um. As matrizes de acetato foram, 
então, preenchidas com a resina composta e posicionadas sobre a porção coronária do pino. Os excessos foram removidos e uma fotoativação suplementar foi realizada durante 40 segundos em cada face. Após a polimerização, as matrizes de acetato foram seccionadas restando, desta forma, os núcleos de preenchimento. As amostras foram armazenadas em soro fisiológico à $0,9 \%$ até a realização dos testes de resistência à fratura (Figura 6)
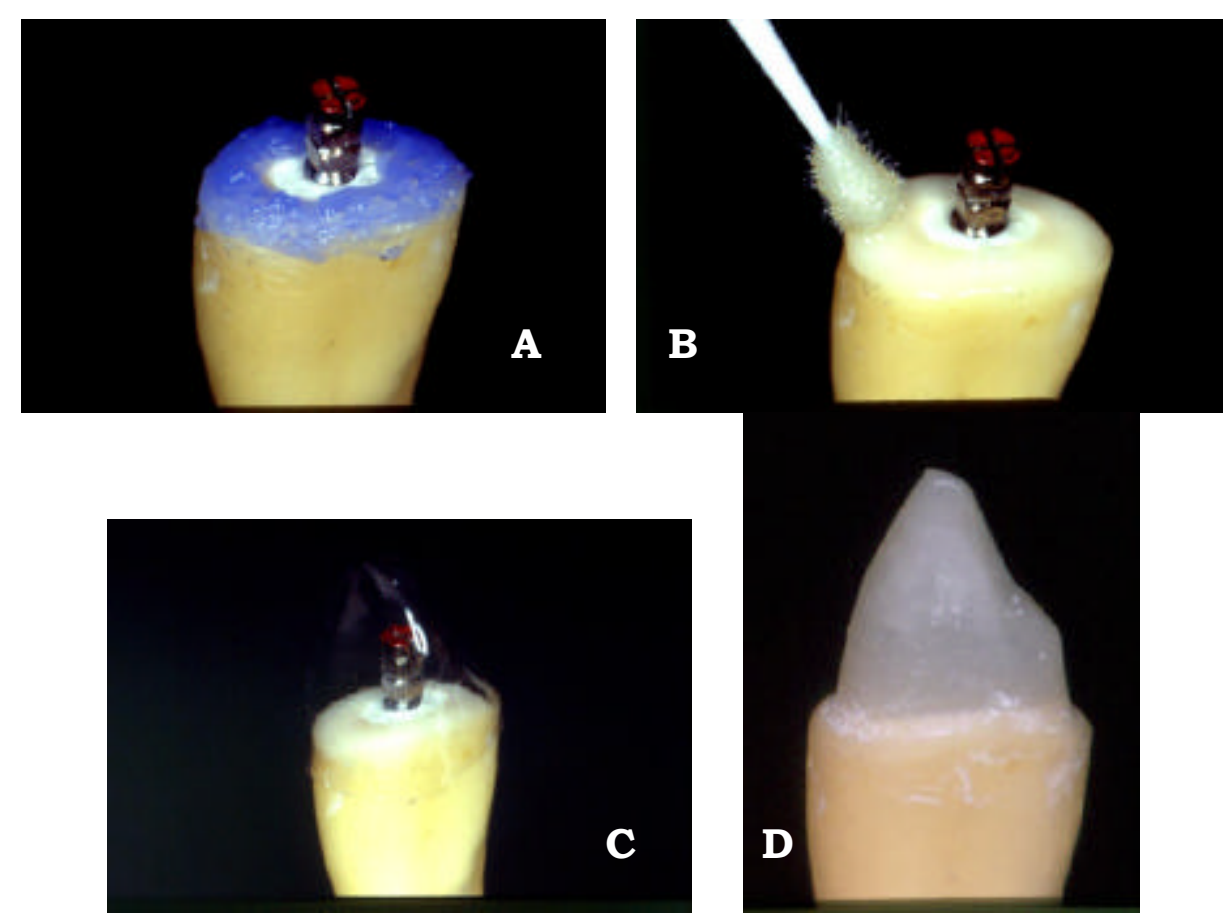

FIGURAS 6: Confecção dos núcleos de preenchimento
A) Ataque ácido
B) Aplicação do adesivo
C) Adaptação da matriz de acetato
D) Núcleo de preenchimento pronto 


\subsection{INCLUSÃO DOS DENTES}

Após a finalização das etapas anteriores, os dentes foram posicionados e fixados dentro de cilindros de resina autopolimerizável (Clássico - Artigos Odontológicos S/A - Brasil) de 30mm de altura, diâmetro de $22 \mathrm{~mm}$, no limite de $1,5 \mathrm{~mm}$ apical à junção cemento-esmalte e posteriormente levados à Máquina de Ensaios Universal para testes.

\subsection{ENSAIO DE RESISTÊNCIA À FRATURA (forças aplicadas $\mathrm{em} 45^{\circ}$ )}

Para a realização dos testes de resistência à fratura foi utilizada uma Máquina de Ensaios Universal (Dinamômetros KRATOS Ltda, São Paulo Brasil) utilizando uma célula de carga número 2 (100Kg), e velocidade de $0,5 \mathrm{~mm} / \mathrm{min}^{70,96,102}$. Os corpos de prova receberam uma força de compressão incidindo em ângulo de $135^{\circ}$ com o longo eixo da raiz (ângulo de $45^{\circ} \mathrm{em}$ relação ao plano horizontal) simulando um contato oclusal do dente antagonista em classe I de Angle (Figura 7). 


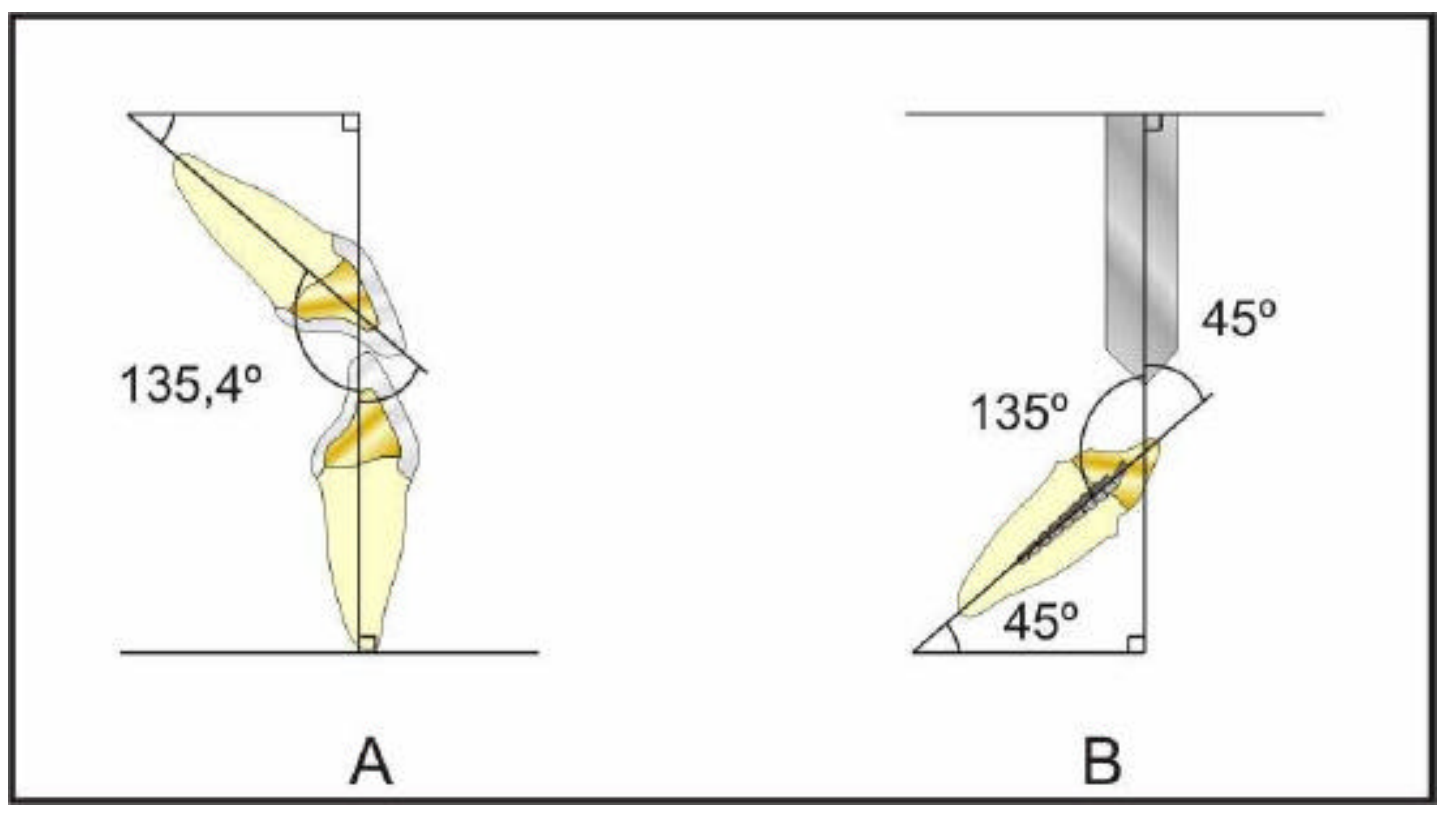

Figura 7 - Esquema da aplicação de força à $45^{\circ}$

A) Ângulo de $135,4^{\circ}$ formado pelo contato oclusal entre os incisivos centrais superiores e inferiores em classe I de Angle; B) Representação esquemática da força de compressão incidindo em ângulo de $135^{\circ}$ em relação ao longo eixo da raiz, ou seja, um ângulo de $45^{\circ}$ em relação ao plano horizontal.

Para aplicação de forças em $45^{\circ}$ nos testes de resistência foi desenvolvido um dispositivo especial que se adaptava à porção inferior da máquina de ensaios. A posição do corpo de prova neste dispositivo permitia ao núcleo ficar posicionado em uma inclinação de 45ำ (Figura 8).
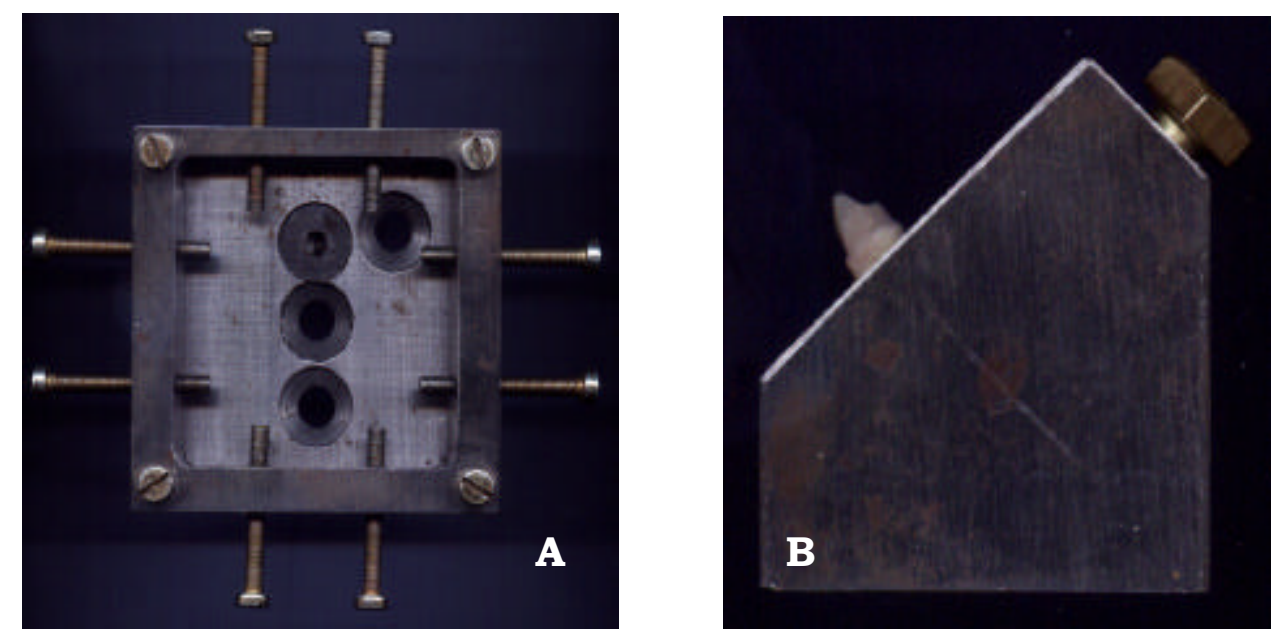

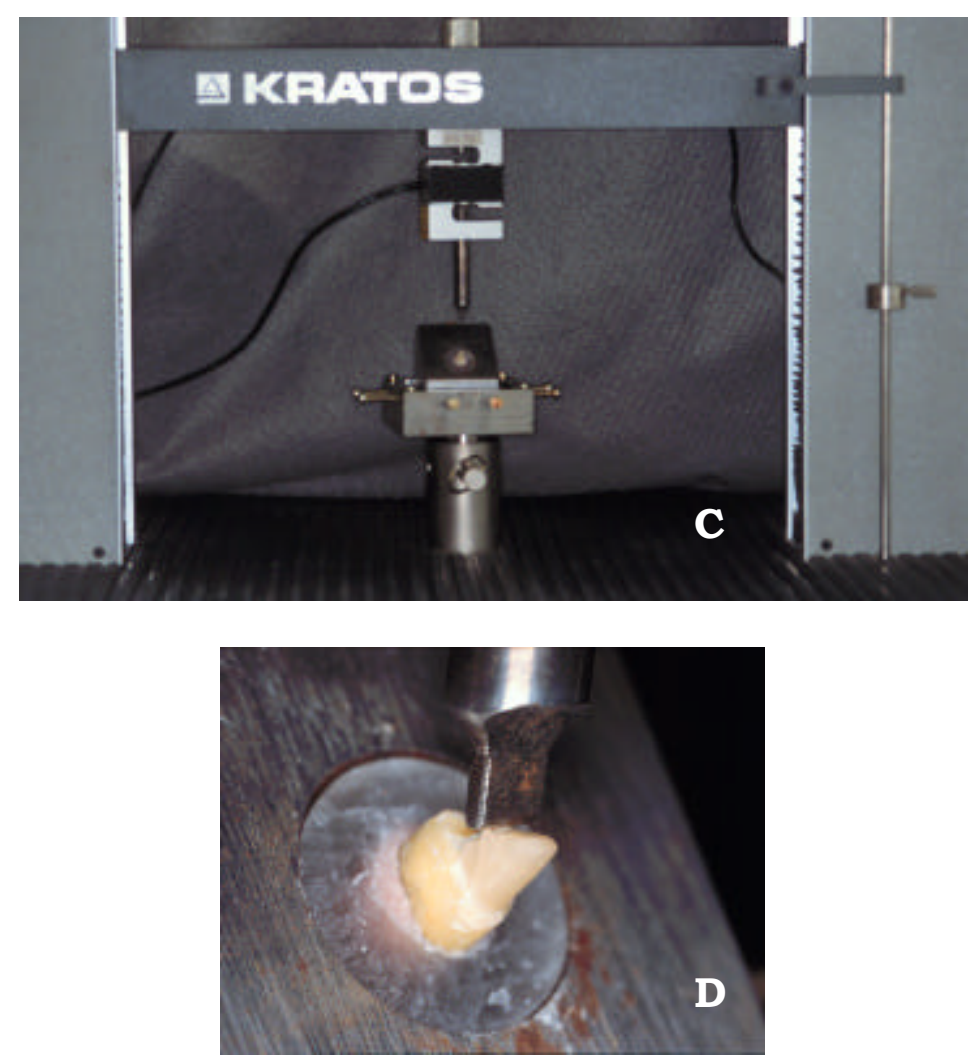

FIGURA 8: Visualização do aparato utilizado para a fixação e posicionamento dos corpos de prova submetidos ao teste de resistência à fratura em uma Máquina de Ensaios Universal.
A) Porção inferior que se une a Máquina de ensaio Universal
B) Porção superior que posiciona o corpo de prova a $45^{\circ}$
C) Aparato pronto para receber a força de compressão na Máquina de ensaio Universal
D) Força aplicada a um ângulo de $45^{\circ}$

Os valores em $\mathrm{kgF}$ das forças necessárias para provocar a falha do conjunto dente/núcleo de cada grupo foram anotados e organizado em tabelas para futuro tratamento estatístico 


\section{RESULTADOS}




\section{RESULTADOS}

Para a análise dos resultados foi utilizado o teste de Análise de Variância (ANOVA) a um critério $(p<0,05)$ que constatou a presença de uma diferença estatisticamente significativa entre os grupos (Tabela 2), desta forma realizourse a comparação das médias através do teste de Tukey para comparações múltiplas $(p<0,05)$ (Tabela 3).

TABELA 2: Teste estatístico de análise de variância a um critério aplicado aos valores de resistência à fratura.

\begin{tabular}{|c|c|c|c|c|c|c|}
\hline Efeito & $\begin{array}{c}\text { gl } \\
\text { Efeito }\end{array}$ & $\begin{array}{c}\text { QM } \\
\text { Efeito }\end{array}$ & $\begin{array}{c}\text { gl } \\
\text { Efeito }\end{array}$ & $\begin{array}{c}\text { QM } \\
\text { Efeito }\end{array}$ & $\mathbf{F}$ & $p$ \\
\hline $\begin{array}{c}\text { Tipo de } \\
\text { Reconstrução }\end{array}$ & $5^{\star}$ & $1664,252^{*}$ & $36^{*}$ & $213,4185^{\star}$ & $7,798070^{*}$ &, $000014^{*}$ \\
\hline
\end{tabular}


TABELA 3: Comparações individuais das médias - Teste de Tukey

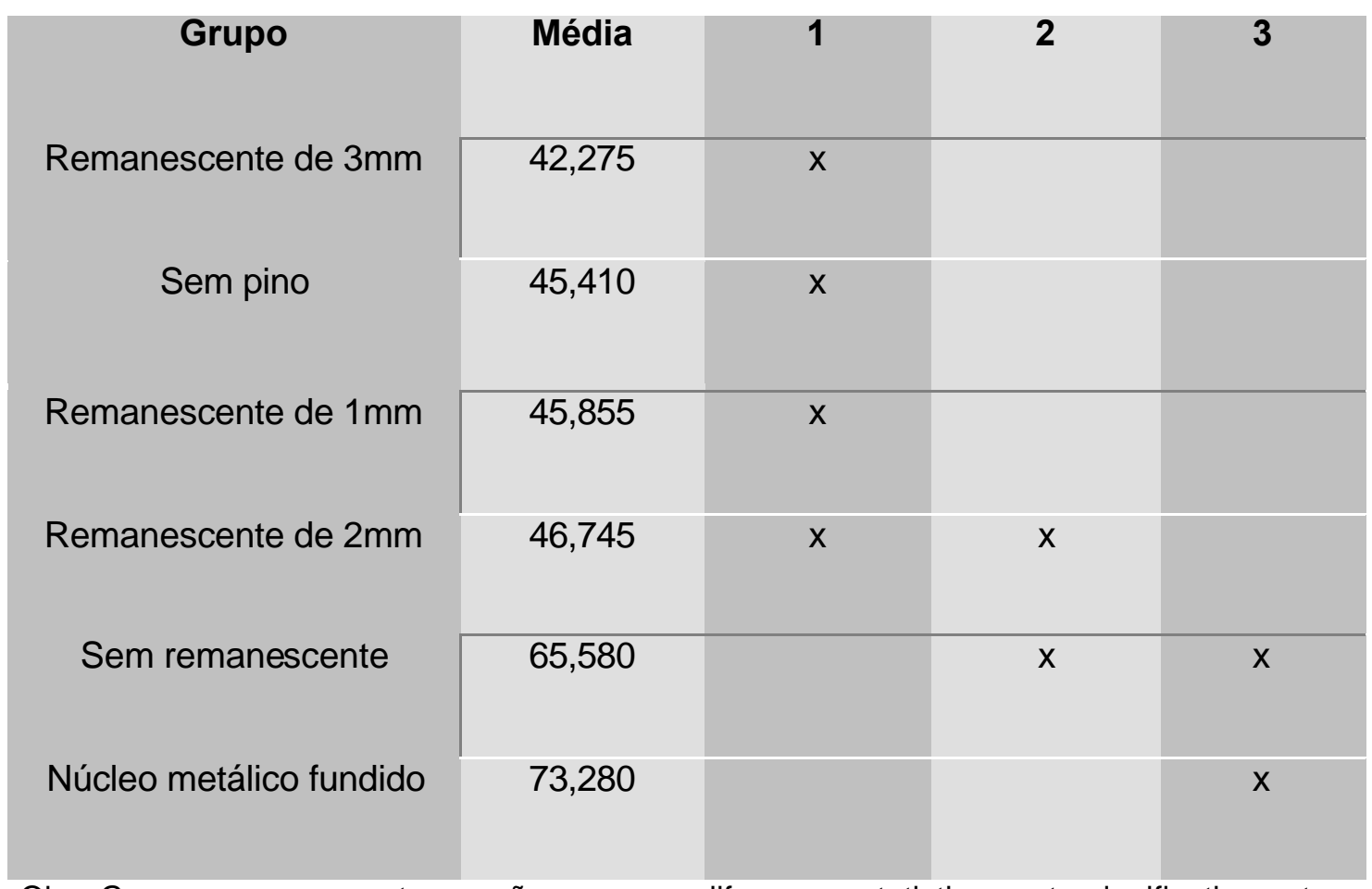

Obs: Grupos que apresentam x não possuem diferença estatisticamente significativa entre si $(p<0,05)$

$\mathrm{Na}$ Tabela 4 podemos observar os valores individuais, médias e desvios padrão da resistência a fratura dos grupos testados neste estudo. A figura 9, para melhor visualização dos resultados, organiza em colunas coloridas as médias de resistência à fratura de cada grupo. 
TABELA 4: Valores individuais, médias e respectivos desvios padrão para cada condição experimental (valores em kgf.)

\begin{tabular}{|c|c|c|c|c|c|c|}
\hline & GRUPOI & GRUPO॥I & GRUPO III & GRUPOIV & GRUPOV & GRUPOV \\
\hline ESPÉCIME & sempino & $\begin{array}{l}\text { núcleo } \\
\text { Fundido }\end{array}$ & $\begin{array}{l}\text { Sem } \\
\text { remanescente }\end{array}$ & $\begin{array}{c}1 \mathrm{~mm} \text { de } \\
\text { Remanescente }\end{array}$ & $\begin{array}{c}2 \mathrm{~mm} \text { de } \\
\text { Remanescente }\end{array}$ & $\begin{array}{c}\text { 3mmde } \\
\text { Remanescente }\end{array}$ \\
\hline 1 & 57,7 & 88,4 & 79,4 & 37,6 & 47,2 & 42,5 \\
\hline 2 & 62,2 & 57,6 & 78,3 & 67,9 & 84,1 & 34,9 \\
\hline 3 & 57,1 & 59,35 & 95,1 & 35,8 & 47,8 & 46,2 \\
\hline 4 & 37,05 & 61,7 & 35,1 & 36,5 & 44,7 & 40,2 \\
\hline 5 & 60,3 & 67,5 & 46,9 & 58,5 & 35,2 & 50,6 \\
\hline 6 & 41,7 & 110,0 & 55,5 & 36,6 & 47,8 & 45,8 \\
\hline 7 & 21,3 & 66,9 & 51,0 & 42,4 & 48,1 & 37,5 \\
\hline 8 & 32,7 & 69,3 & 63,9 & 59,7 & 44,6 & 24,5 \\
\hline 9 & 42,8 & 71,7 & 94,5 & 42,0 & 27,0 & 53,5 \\
\hline 10 & 41,2 & 80,2 & 55,9 & 41,5 & 40,7 & 47,0 \\
\hline Média & 45,4 & 73,2 & 65,5 & 45,8 & 46,7 & 42,2 \\
\hline $\begin{array}{l}\text { Desvio } \\
\text { Padrão }\end{array}$ & 13,4 & 15.9 & 20,4 & 11,6 & 14,7 & 8,4 \\
\hline
\end{tabular}




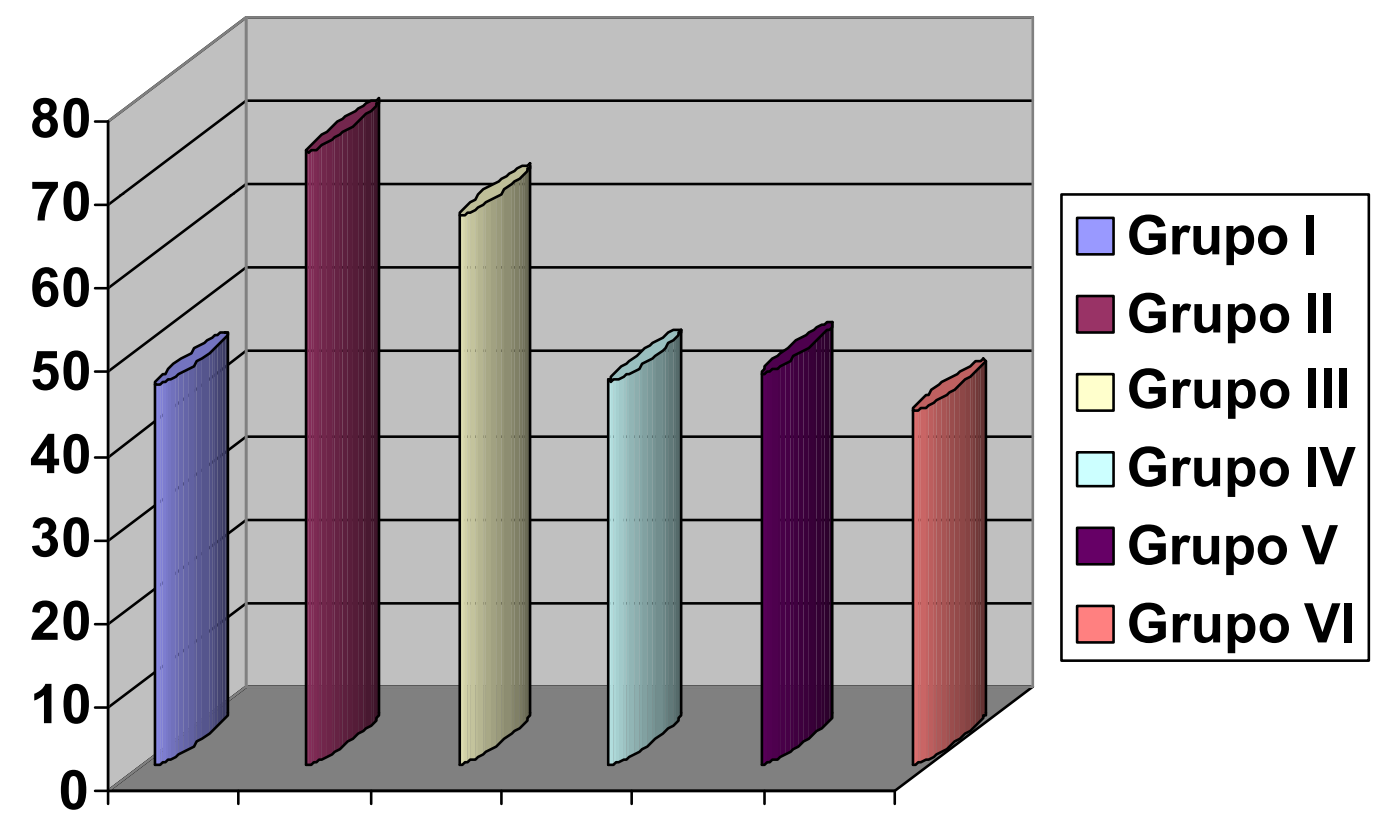

FIGURA 9: Representação gráfica das médias de resistência à fratura dos seis grupos experimentais. 


\section{DISCUSSÃO}

A reabilitação estrutural de um dente despolpado torna-se um elemento fundamental para o sucesso final da restauração após o tratamento endodôntico. Apesar da grande quantidade de pesquisas científicas e da enorme gama de materiais restauradores disponíveis no mercado, continua duvidosa a decisão sobre qual seria o melhor plano de tratamento a ser realizado.

Historicamente, a restauração de dentes tratados endodonticamente tem sido realizada de uma forma empírica, com seus resultados sendo, nem sempre, muito previsíveis. Muitas das decisões tomadas pelos profissionais, sobre qual a maneira ideal de se realizar um tratamento, são baseadas em experiências clínicas passadas ao invés de seguir um protocolo específico. Apesar disso, recentemente, o avanço tecnológico e científico no campo da endodontia, periodontia e das técnicas restauradoras possibilitou que os resultados se tornassem muito mais previsíveis. Dessa forma, dentes que de outra maneira estariam perdidos são tratados endodonticamente e restaurados, cumprindo adequadamente todas as funções que lhes são atribuídas.

Tradicionalmente, dois sistemas de retenção intra-radicular têm sido recomendados. O primeiro sistema reproduz a morfologia do espaço do canal radicular e a porção coronária do dente tratado através de um núcleo metálico fundido, enquanto, o segundo sistema utiliza-se de um pino préfabricado cimentado dentro do canal e porção coronária restaurada com um 
material de preenchimento.

Durante muitos anos, o material de escolha para este tipo de restauração foram os núcleos metálicos fundidos. Atualmente o mercado foi invadido por uma enorme quantidade de pinos pré-fabricados associados ao material de preenchimento, tal como a resina composta ${ }^{27,74}$. Segundo MORGANO $^{99}$ os pinos pré-fabricados têm sido preferidos pela grande maioria dos profissionais americanos devido a sua facilidade e rapidez de confecção.

Diferentes tipos de pinos pré-fabricados estão disponíveis no mercado. Cada um destes possui características benéficas e maléficas quando da realização de suas funções, por exemplo, os pinos paralelos e rosqueáveis que são mais retentivos ${ }^{55,91,92,94}$, mas, por outro lado, necessitam de um maior desgaste da região apical da raiz favorecendo o seu enfraquecimento ${ }^{94}$. A escolha de pinos mais longos e delgados possibilita uma melhor distribuição de tensões ${ }^{60,107}$ e preservação de estrutura dental sadia ${ }^{153}$. Por isso, os pinos com extremidade cônica permitem um maior volume de dentina na porção média e apical da raiz reduzindo o risco de fratura do elemento dentário ${ }^{27,103}$.

Neste estudo, utilizaram-se pinos de aço inoxidável de paredes paralelas e extremidade cônica utilizados de maneira passiva, por seu comprovado sucesso em testes laboratoriais de resistência e tração $55,91,92,94,103$. Além disso, suas paredes paralelas possibilitam uma maior efetividade na retenção ${ }^{91,92103}$ e o desenho cônico de sua extremidade se assemelha muito mais à configuração do canal, preservando estrutura 
dentária na região apical e exercendo concentrações mais baixas de força de tensão, provavelmente devido à ausência de ângulos agudos ${ }^{5,134}$. A sua superfície serrilhada possibilita maior retenção e resistência ao deslocamento quando comparado com a de superfície lisa.

A fratura do elemento dentário remanescente quando se utilizam pinos intra-radiculares é uma das causa mais comuns de insucesso. Para prevenir este tipo de situação devem ser observados, obrigatoriamente, os princípios biomecânicos básicos relacionados a estas restaurações, adotando, desta forma, técnicas e utilizando materiais que possibilitem que o elemento dental possa exercer adequadamente suas funções, seja individualmente ou como suporte de prótese fixa ou removível ${ }^{14,29}$.

Segundo muitos autores $5,14,37,41,50,69,120,152$ a principal causa da fragilidade de um dente despolpado é a perda de umidade. GUTMANN ${ }^{50}$ relatou que um dente despolpado apresenta a umidade da dentina coronária diminuída para $13,2 \%$ e a perda de umidade na dentina radicular ainda maior, fazendo com que a sua capacidade de deformação elástica seja prejudica$\mathrm{da}^{50,62}$, devendo, portanto, realizar uma restauração que além de substituir a estrutura perdida, devolvesse a resistência adequada ao remanescente dentário. FUSAYAMA; MAEDA ${ }^{45}$ disseram que a remoção do tecido pulpar não diminui a resistência da dentina, mas cessa o seu crescimento e maturação resultando numa dentina mais delgada e enfraquecida quando comparada com um dente integro. Diferente dos dois últimos autores STOKES ${ }^{148}$ defende a idéia que um dente que passa por uma intervenção endodôntica 
com mínima perda dentinária, não é mais susceptível à fratura que um dente vital, o que está de acordo com MILOT; STEIN ${ }^{95}$, que complementam dizendo ainda, que o tipo de núcleo ou pino utilizado tem pouca importância quando a maioria da estrutura dentinária é preservada. Apesar dessa discordância, existe o consenso de que é fundamental a preservação das estruturas radicular e coronária remanescente para melhor prognóstico restaurador, pois a perda de estruturas importantes como cristas marginais e pontes de esmalte enfraquecem significativamente os dentes polpados e despolpa$\operatorname{dos}^{37,50,84,89,96,98,125,155}$.

A grande maioria das técnicas utilizadas no tratamento de dentes extremamente destruídos tem se baseado na construção de núcleos intraradiculares com o objetivo de proporcionar retenção a futura restauração e de reforçar o remanescente dentário ${ }^{9,10,37,71,81,131}$, no entanto, tem sido observado que estes núcleos não são capazes de reforçar o dente estruturalmente debilitado $5,48,62,88,110,136,147,154,158$, sendo que alguns autores ${ }^{19,22,154}$ ainda mostram que estes retentores intra-radiculares tem o potencial de enfraquecê-los.

Para a desobstrução do canal radicular, dos dentes utilizados neste trabalho, foi utilizada a broca correspondente ao pino de acordo com o Kit Euro-Post, o qual permitiu com que houvesse uma padronização dos preparos removendo a menor quantidade de estrutura dental possível seguindo os princípios de preservação de estrutura dentária ${ }^{22,153}$.

Os resultados encontrados neste estudo mostraram que os pinos pré- 
fabricados não podem ser considerados mecanismos de reforço para dentes despolpados quando estes possuírem algum remanescente dentário coronal, pois, os valores de resistência à fratura $(44,958 \mathrm{~kg})$ foram muito próximos dos encontrados para os dentes que não receberam retenção intra-radicular $(45,410 \mathrm{~kg})$. Estes dados estão de acordo com outros autores, tais como ASSIF; GORFIL ${ }^{5}$, MANNING ${ }^{84,85}$, CHRISTENSEN ${ }^{27}$, MORGANO ${ }^{99}$ e SMITH; SCHURMAN ${ }^{134}$ que defendem a idéia de que a única função de um pino é a de proporcionar retenção e que, por isso, devem ser utilizados somente quando não houver quantidade suficiente de remanescente dentário coronal para suportar uma futura restauração protética.

Confrontando os resultados encontrados para os dentes sem retenção intra-radicular $(45,410 \mathrm{Kg})$ com os dos dentes restaurados com núcleos fundidos $(73,280 \mathrm{Kg})$ e com os dos dentes sem remanescente coronal restaurados com pinos pré-fabricados $(65,580 \mathrm{Kg})$ pode-se observar que os primeiros foram significantemente mais sensíveis.

Isto pode ser explicado, no caso do núcleo fundido, pelo fato do material ser rígido, apresentar resistência muito maior do que a estrutura dentária e, segundo $\mathrm{ASSIF}^{4}$, um módulo de elasticidade muito maior do que a da estrutura dental com um potencial de fratura radicular. No caso dos pinos préfabricados utilizados em dentes sem remanescente coronal pode-se justificar o resultado pelo alto conteúdo de carga incorporada a matriz da resina composta Z-100, possível devido ao tamanho e forma de suas partículas, totalizando $66 \%$ do seu volume. Este maior conteúdo de carga inorgânica corres- 
ponde à máxima resistência à compressão, dureza superficial e resistência ao desgaste ${ }^{1}$.

Ao consultar a literatura, pode-se observar que existem muitos estudos analisando a influência do retentor intracanal, da remoção de dentina radicular e do próprio tratamento endodôntico sobre a resistência de dentes tratados endodonticamente, no entanto, a influência do remanescente dentário coronal, sobre dentes que se encontram nessa mesma situação, ainda é motivo de controvérsias.

Uma grande dúvida permanece sobre qual a quantidade de estrutura dentária coronal necessária para prover resistência suficiente para suportar as forças exercidas sobre o conjunto dente/restauração. Além disso, não se sabe se a quantidade deste remanescente é proporcional à resistência do dente tratado, ou seja, quanto maior o remanescente coronal maior seria a resistência à fratura.

A análise dos resultados do presente trabalho permitiu concluir que os dentes restaurados com pinos pré-fabricados sem a existência de qualquer estrutura dentária coronal é no mínimo $28,7 \%$ mais resistente à fratura do que aqueles que apresentavam $1 \mathrm{~mm}, 2 \mathrm{~mm}$ ou $3 \mathrm{~mm}$ de remanescente. Esta diferença significante de resistência pode ser compreendida quando se observa a alta quantidade de carga inorgânica da resina composta. ABDALLA E ALHAYDAINY ${ }^{1}$ relataram que a alta resistência da resina se deve ao fato dela possuir um alto conteúdo de carga incorporada a sua matriz tornando-a muito resistente a compressão e ao desgaste e possuir uma grande dureza 
superficial. REAGAN ${ }^{115}$, ainda, atribuiu esta maior resistência da resina ao seu baixo módulo de elasticidade que permite uma melhor absorção de impactos durante os testes de fadiga mecânica. O maior volume de material utilizado nos dentes sem remanescente coronal quando comparado aos que possuíam pode ter intensificado estas características, e dessa forma dado uma maior resistência àquele grupo.

Os resultados encontrados estão de acordo aos encontrados por GEGAUFF $^{46}$ que observou que dentes sem remanescente coronal eram capazes de resistir mais às forças de fadiga do que aqueles que possuíam $2 \mathrm{~mm}$ deste. No entanto, SORENSEN ${ }^{138}$ contradiz estes resultados concluindo que o aumento de $1 \mathrm{~mm}$ de remanescente, aproximadamente, duplica a resistência fratura do dente tratado endodonticamente. LONEY; KOTOWIEZ; McDOWEL $^{82}$ e KAHN $^{69}$ afirmaram que a manutenção de $1 \mathrm{~mm}$ da porção coronal de um dente era suficiente para aumentar a resistência deste. ISIDOR ${ }^{66}$, da mesma forma que os autores anteriores, conclui que a presença de remanescente coronal diminui o risco de fratura.

Quando observamos isoladamente os grupos que possuíam algum remanescente dentário coronal pudemos observar que não houve diferença estatisticamente significativa entre eles (Grupo IV (1mm) - 45,855Kg; Grupo V $(2 \mathrm{~mm})-46,745 \mathrm{Kg}$; Grupo VI (3mm) - 42,275Kg). Isto significa que quando existe alguma porção coronária remanescente, a quantidade desta não influencia na resistência à fratura do dente tratado.

SORENSEN ${ }^{138}$ confirma estes resultados no trabalho que realizou 
procurando avaliar a resistência à fratura de dentes tratados endodonticamente. $\mathrm{O}$ autor preservou $1 \mathrm{~mm}$ ou $2 \mathrm{~mm}$ de remanescente dentário coronal e não observou diferença estatística entre ambos os grupos. Diferentemente ocorreu no trabalho realizado por ISIDOR ${ }^{66}$ que observou que o aumento da altura da porção coronária foi acompanhado por um aumento na resistência à fratura do dente tratado.

Para a aplicação das forcas a um ângulo de 45ํao longo eixo do dente, os autores deste trabalho idealizaram um suporte metálico com o objetivo de minimizar todas as variáveis possíveis.

A aplicação de uma força numa angulação de $45^{\circ}$ ao longo eixo do dente foi idealizada com o intuito de aproximar, o máximo possível, com os tipos de força que ocorrem na boca, que seria uma associação de compressão e cisalhamento ${ }^{100}$. Especula-se que KANTOR; PINES ${ }^{71}$, simulando as cargas oblíquas geradas durante a função incisal ou desoclusão do guia anterior, tenham sido os primeiros autores a testar núcleos metálicos fundidos com cargas compressivas aplicadas a 45ํ․ dois anos depois de MOYERS ${ }^{100}$ relatar que em um padrão normal de oclusão, o ângulo formado entre os dentes anteriores superiores e inferiores é de aproximadamente 135‥

Para que fosse possível a realização dos testes de compressão deste trabalho foi necessária a confecção de um corpo de prova de resina acrílica, onde os dentes foram incluídos a $2 \mathrm{~mm}$ aquém do limite amelo cementário $^{51,90,153}$, simulando a altura óssea que normalmente é encontrada. A opção de não simular o ligamento periodontal foi devido ao fato deste 
procedimento, realizado através da incorporação de silicone, parecer duvidoso devido à falta de estudos que comprovem que este material apresenta as mesmas características de visco elasticidade do mesmo ${ }^{70}$.

Quando, observando os resultados deste trabalho, chegou-se à conclusão de que a presença do pino não reforçaria a estrutura dentária e uma explicação mecânica deveria ser encontrada. HOMES; DIAZ-ARNOLD; LERY $^{60}$, HUANG; SCHILDER; NATHANSON ${ }^{62}$ sugerem que no momento em que a força é aplicada sobre a face palatina do dente, o apoio se torna a crista óssea vestibular do rebordo alveolar, como conseqüência ocorre uma concentração de tensões de compressão na face vestibular do dente, em oposição as forças de tração encontradas na face palatina. $O$ conjunto destas forças tração e compressão, segundo os autores, se anulam no centro longitudinal do dente, exatamente onde está cimentado o pino intracanal, desta forma, quanto mais próximo a região estiver da superfície do dente, maior a magnitude dessas tensões, necessitando assim de um reforço periférico e não no centro do dente.

$\mathrm{Na}$ ausência de um pino intra-radicular, Mc DONALD; KING; SETCHELL $^{90}$ relatam que no instante em que o dente recebe uma força exacerbada, que ultrapassa o limite de proporcionalidade, pode ocorrer o início de uma trinca ou fratura, provavelmente na face palatina, onde os prismas de esmalte estão sob forças de tração. Essa linha de fratura pode se propagar no sentido transversal do ponto de aplicação de carga ao ponto de apoio sobre a crista óssea. 
Segundo GUSY; NICHOLLS ${ }^{51}$ o padrão de fratura descrito acima pode ser modificado na presença de um pino intracanal cimentado no interior do conduto, ou seja, quando a linha de fratura atinge a região central do conduto onde o pino está localizado, este dissipa parte das tensões através do seu corpo, dirigindo a trinca também no sentido longitudinal da raiz.

Quando analisamos o padrão de fratura encontrado em nosso trabalho podemos observar que $100 \%$ do dentes reconstruídos com núcleos metálicos fundidos tiveram fratura longitudinal de raiz, o que esta de acordo com os trabalhos de BEX ${ }^{16}$, FRAGA ${ }^{43}$, AKKAYAN; CANIKLIOGLU ${ }^{2}$, MARTINEZ-INSUA ${ }^{88}$ e pode ser explicado pela alta rigidez do material, sendo este muito mais resistente que a estrutura dental, o que fazia com que a falha do conjunto dente/restauração ocorresse somente quando houvesse a fratura radicular.

Em relação ao restante dos dentes testados, o grupo que não recebeu retenção intra-radicular teve $100 \%$ de fratura do remanescente dentário, apesar disso, todos se apresentaram com possibilidade de reparo, pois, como se pode observar neste estudo, a fratura sempre ocorreu acima da região da crista óssea. Os grupos restaurados com pinos pré-fabricados com dentes com remanescentes coronários de $0 \mathrm{~mm}, 1 \mathrm{~mm}, 2 \mathrm{~mm}$ e $3 \mathrm{~mm}$ apresentaram $90 \%, 100 \%, 80 \%$ e $80 \%$ de falha no material de preenchimento, respectivamente. Nenhum dos dentes restaurados com pinos intra-radiculares pré-fabricados apresentaram, após os testes, fratura radicular. Estes resultados estão de acordo com BEX et al. ${ }^{16}$, SIDOLI; 
KING; SETCHELL ${ }^{130}$, FRAGA ${ }^{43}$, AKKAYAN; CANIKLIOGLU ${ }^{2}$ os quais salientaram que os núcleos de resina composta quando falham são passíveis de serem reparados o que não acontece com materiais rígidos, como os núcleos metálicos fundidos, que levam geralmente a fratura radicular condenando o elemento dental.

Os resultados encontrados neste trabalho mostraram que $83,3 \%$ dos dentes testados, independente do tipo de falha, seriam capazes de serem restaurados, enquanto somente $16,7 \%$ estariam perdidos, sendo que, todos estes, foram restaurados com núcleos metálicos fundidos.

O tipo de fratura encontrado neste trabalho poderia ser modificada pela presença de uma coroa total. ASSIF et al. ${ }^{5}$, HOAG \& DWYER ${ }^{59}$ e GELFAND et al. ${ }^{47}$ relataram que quando os testes de resistência à fratura são feitos sobre uma coroa total, com margens em estrutura dental sadia, os materiais empregados como núcleos não exercem influência no resultado de resistência à fratura.

Além disso, autores como SORENSEN; ENGELMAN ${ }^{139}$, BARKHORDAR; RADKE; ABBASI ${ }^{13}$, têm sugerido que o efeito férula aumenta significativamente a resistência dos dentes tratados endodonticamente à fratura, assim como a estabilidade da coroa instalada sobre estes dentes.

Para a realização desta pesquisa optou-se pela não utilização de uma coroa total, pois a intenção dos autores foi testar a resistência dos dentes 
estudados, sob o pior tipo de situação, ou seja quando a coroa não estivesse presente, da mesma forma que foi comentado por COHEN et al. ${ }^{34}$.

Os resultados encontrados neste estudo foram satisfatórios quando comparados aos resultados encontrados por LYONS ${ }^{83}$ que demonstrou que a força média que os dentes caninos apresentam na força de mordida máxima é de, aproximadamente, $22 \mathrm{~kg}$, pacientes bruxomanos apresentaram forças próximas de $26 \mathrm{~kg}$ e observou ainda que as forças máximas encontradas nessa mesma região foram de 32 e $35 \mathrm{~kg}$. É importante ressaltar que nenhum dos dentes testados neste trabalho estariam sujeitos a falhas quando o paciente estivesse sob função ou parafunção.

Através dos dados encontrados pôde-se observar que se o sucesso de uma prótese depender exclusivamente da resistência de dentes tratados endodonticamente, o tipo de núcleo intra-radicular pouco influenciará. A maior vantagem de um sobre o outro seria a da fratura de um dente restaurado com pino pré-fabricado e núcleo de preenchimento não comprometer totalmente o dente tratado, possibilitando assim o seu reparo coronal. Dessa forma, outros estudos devem ser realizados a fim de elucidar a atuação do remanescente dentário coronal e do núcleo de preenchimento quando estes estiverem recobertos por uma coroa e ainda receberem cargas aplicadas de maneira intermitente, o que aproximaria muito mais a condições reais existentes na boca. 


\section{CONCLUSÕES}

De acordo com os objetivos propostos, os resultados obtidos e a análise estatística podemos concluir que:

7.1 Não houve diferença estatisticamente significativa na resistência

à fratura entre os dentes que apresentavam remanescente dentário coronal;

7.2 Os resultados dos dentes restaurados com pinos pré-fabricados sem remanescente dentário coronal foram semelhantes àqueles encontrados para os núcleos metálicos fundidos, não havendo diferença estatisticamente significativa entre si;

7.3 Os dentes que não receberam retenção intra-radicular não apresentaram diferença estatisticamente significativa comparados com os dentes restaurados com pinos préfabricados com remanescente coronal;

7.4 Os dentes restaurados com núcleos metálicos fundidos e com pinos intra-radiculares sem remanescente coronal foram significantemente mais resistentes, seguido dos dentes restaurados com pinos intra-radiculares com $2 \mathrm{~mm}$ de remanescente, $1 \mathrm{~mm}$, dos dentes sem retenção intra-radicular e dos dentes com $3 \mathrm{~mm}$ de remanescente coronal, estes não apresentaram diferença estatística entre si; 
ANEXOS 


\section{ANEXOS}

TABELA 4: Padrão de fraturas

\begin{tabular}{|c|c|c|c|c|c|c|}
\hline 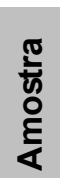 & $\begin{array}{c}\text { Sem pino } \\
\text { Grupo I }\end{array}$ & $\begin{array}{l}\text { Núcleo } \\
\text { metálico } \\
\text { Fundido } \\
\text { grupoll }\end{array}$ & $\begin{array}{c}\text { Sem } \\
\text { remanescente } \\
\text { Grupo III }\end{array}$ & $\begin{array}{c}1 \mathrm{~mm} \text { de } \\
\text { remanescente } \\
\text { Grupo IV }\end{array}$ & $\begin{array}{c}2 \mathrm{~mm} \text { de } \\
\text { remane scente } \\
\text { grupo V }\end{array}$ & $\begin{array}{c}3 \mathrm{~mm} \text { de } \\
\text { remanescente } \\
\text { grupo Vl }\end{array}$ \\
\hline 01 & $\begin{array}{c}57,7 \\
\text { Fratura do } \\
\text { remanescente } \\
\text { reparável }\end{array}$ & $\begin{array}{c}88,4 \\
\text { Fraturou } \\
\text { a raiz }\end{array}$ & $\begin{array}{c}79,4 \\
\text { Fratura da resina } \\
\text { e do } \\
\text { remanescente } \\
\text { reparável }\end{array}$ & $\begin{array}{c}37,6 \\
\text { Fraturou a } \\
\text { resina }\end{array}$ & $\begin{array}{c}47,2 \\
\text { Fraturou a } \\
\text { resina }\end{array}$ & $\begin{array}{c}42,5 \\
\text { Fraturou a } \\
\text { resina }\end{array}$ \\
\hline 02 & $\begin{array}{c}62,2 \\
\text { Fratura do } \\
\text { remanescente } \\
\text { reparável }\end{array}$ & $\begin{array}{c}57,6 \\
\text { Fraturou } \\
\text { a raiz }\end{array}$ & $\begin{array}{c}78,3 \\
\text { Fraturou a } \\
\text { resina }\end{array}$ & $\begin{array}{c}67,9 \\
\text { Fraturou a } \\
\text { resina }\end{array}$ & $\begin{array}{c}84,1 \\
\text { Fratura da } \\
\text { resina e do } \\
\text { remanescente } \\
\text { reparável }\end{array}$ & $\begin{array}{c}34,9 \\
\text { Fraturou a } \\
\text { resina }\end{array}$ \\
\hline 03 & $\begin{array}{c}57,1 \\
\text { Fratura do } \\
\text { remanescente } \\
\text { reparável }\end{array}$ & $\begin{array}{c}59,35 \\
\text { Fraturou } \\
\text { a raiz }\end{array}$ & $\begin{array}{c}95,1 \\
\text { Fraturou a } \\
\text { resina }\end{array}$ & $\begin{array}{l}35,8 \\
\text { Fraturou a } \\
\text { resina }\end{array}$ & $\begin{array}{c}47,8 \\
\text { Fraturou a } \\
\text { resina }\end{array}$ & $\begin{array}{c}46,2 \\
\text { Fraturou a } \\
\text { resina }\end{array}$ \\
\hline 04 & $\begin{array}{c}37,0 \\
\text { Fratura do } \\
\text { remanescente } \\
\text { reparável }\end{array}$ & $\begin{array}{c}61,7 \\
\text { Fraturou } \\
\text { a raiz }\end{array}$ & $\begin{array}{c}35,1 \\
\text { Fraturou a } \\
\text { resina }\end{array}$ & $\begin{array}{l}36,5 \\
\text { Fraturou a } \\
\text { resina }\end{array}$ & $\begin{array}{c}44,7 \\
\text { Fraturou a } \\
\text { resina }\end{array}$ & $\begin{array}{c}40,2 \\
\text { Fraturou a } \\
\text { resina }\end{array}$ \\
\hline 05 & $\begin{array}{c}60,3 \\
\text { Fratura do } \\
\text { remanescente } \\
\text { reparável }\end{array}$ & $\begin{array}{c}61,5 \\
\text { Fraturou } \\
\text { a raiz }\end{array}$ & $\begin{array}{c}46,5 \\
\text { Fraturou a } \\
\text { resina }\end{array}$ & $\begin{array}{c}58,5 \\
\text { Fraturou a } \\
\text { resina }\end{array}$ & $\begin{array}{c}35,2 \\
\text { Fratura da } \\
\text { resina e do } \\
\text { remanescente } \\
\text { reparável }\end{array}$ & $\begin{array}{c}50,6 \\
\text { Fraturou a } \\
\text { resina }\end{array}$ \\
\hline 06 & $\begin{array}{c}41,7 \\
\text { Fratura do } \\
\text { remanescente } \\
\text { reparável }\end{array}$ & $\begin{array}{l}110,0 \\
\text { Fraturou } \\
\text { a raiz }\end{array}$ & $\begin{array}{c}55,5 \\
\text { Fraturou a } \\
\text { resina }\end{array}$ & $\begin{array}{c}36,6 \\
\text { Fraturou a } \\
\text { resina }\end{array}$ & $\begin{array}{c}47,8 \\
\text { Fraturou a } \\
\text { resina }\end{array}$ & $\begin{array}{c}45,8 \\
\text { Fraturou a } \\
\text { resina }\end{array}$ \\
\hline 07 & $\begin{array}{c}21,3 \\
\text { Fratura do } \\
\text { remanescente } \\
\text { reparável }\end{array}$ & $\begin{array}{c}66,9 \\
\text { Fraturou } \\
\text { a raiz }\end{array}$ & $\begin{array}{l}51,0 \\
\text { Fraturou a } \\
\text { resina }\end{array}$ & $\begin{array}{c}42,4 \\
\text { Fraturou a } \\
\text { resina }\end{array}$ & $\begin{array}{c}48,1 \\
\text { Fraturou a } \\
\text { resina }\end{array}$ & $\begin{array}{c}37,5 \\
\text { Fraturou a } \\
\text { resina }\end{array}$ \\
\hline 08 & $\begin{array}{c}32,7 \\
\text { Fratura do } \\
\text { remanescente } \\
\text { reparável }\end{array}$ & $\begin{array}{c}69,3 \\
\text { Fraturou } \\
\text { a raiz }\end{array}$ & $\begin{array}{c}63,9 \\
\text { Fraturou a } \\
\text { resina }\end{array}$ & $\begin{array}{c}59,7 \\
\text { Fraturou a } \\
\text { resina }\end{array}$ & $\begin{array}{c}44,6 \\
\text { Fraturou a } \\
\text { resina }\end{array}$ & $\begin{array}{l}24,5 \\
\text { Fratura da } \\
\text { resina e do } \\
\text { remanescente } \\
\text { reparável }\end{array}$ \\
\hline 09 & $\begin{array}{c}42,8 \\
\text { Fratura do } \\
\text { remanescente } \\
\text { reparável }\end{array}$ & $\begin{array}{c}71,2 \\
\text { Fraturou } \\
\text { a raiz }\end{array}$ & $\begin{array}{c}94,5 \\
\text { Fraturou a } \\
\text { resina }\end{array}$ & $\begin{array}{c}42,0 \\
\text { Fraturou a } \\
\text { resina }\end{array}$ & $\begin{array}{c}27,0 \\
\text { Fraturou a } \\
\text { resina }\end{array}$ & $\begin{array}{c}53,5 \\
\text { Fraturou a } \\
\text { resina }\end{array}$ \\
\hline 10 & $\begin{array}{c}41,2 \\
\text { Fratura do } \\
\text { remanescente } \\
\text { reparável }\end{array}$ & $\begin{array}{l}80,25 \\
\text { Fraturou } \\
\text { a raiz }\end{array}$ & $\begin{array}{l}55,9 \\
\text { Fraturou a } \\
\text { resina }\end{array}$ & $\begin{array}{c}41,5 \\
\text { Fraturou a } \\
\text { resina }\end{array}$ & $\begin{array}{c}40,7 \\
\text { Fraturou a } \\
\text { resina }\end{array}$ & $\begin{array}{c}47,0 \\
\text { Fratura da } \\
\text { resina e do } \\
\text { remanescente } \\
\text { reparável }\end{array}$ \\
\hline
\end{tabular}


TABELA 5. Porcentagem dos tipos de falhas encontradas para grupo.

\begin{tabular}{l|cc|c|c}
\hline Tipo de falha & $\begin{array}{c}\text { Fratura da } \\
\text { Resina }\end{array}$ & $\begin{array}{c}\text { Fratura } \\
\text { radicular }\end{array}$ & $\begin{array}{c}\text { Fratura da } \\
\text { resina e } \\
\text { remanescente } \\
\text { reparável }\end{array}$ & $\begin{array}{c}\text { Fratura do } \\
\text { remanescente }\end{array}$ \\
\hline 1 & - & - & - & $100 \%$ \\
\hline 2 & - & $100 \%$ & - & - \\
\hline 3 & $90 \%$ & - & $10 \%$ & - \\
\hline 4 & $100 \%$ & - & - & - \\
\hline 5 & $80 \%$ & - & $20 \%$ & - \\
\hline 6 & $80 \%$ & - & $20 \%$ & $16,7 \%$ \\
\hline Total & $58,3 \%$ & $16,7 \%$ & $8,3 \%$ & - \\
\hline
\end{tabular}



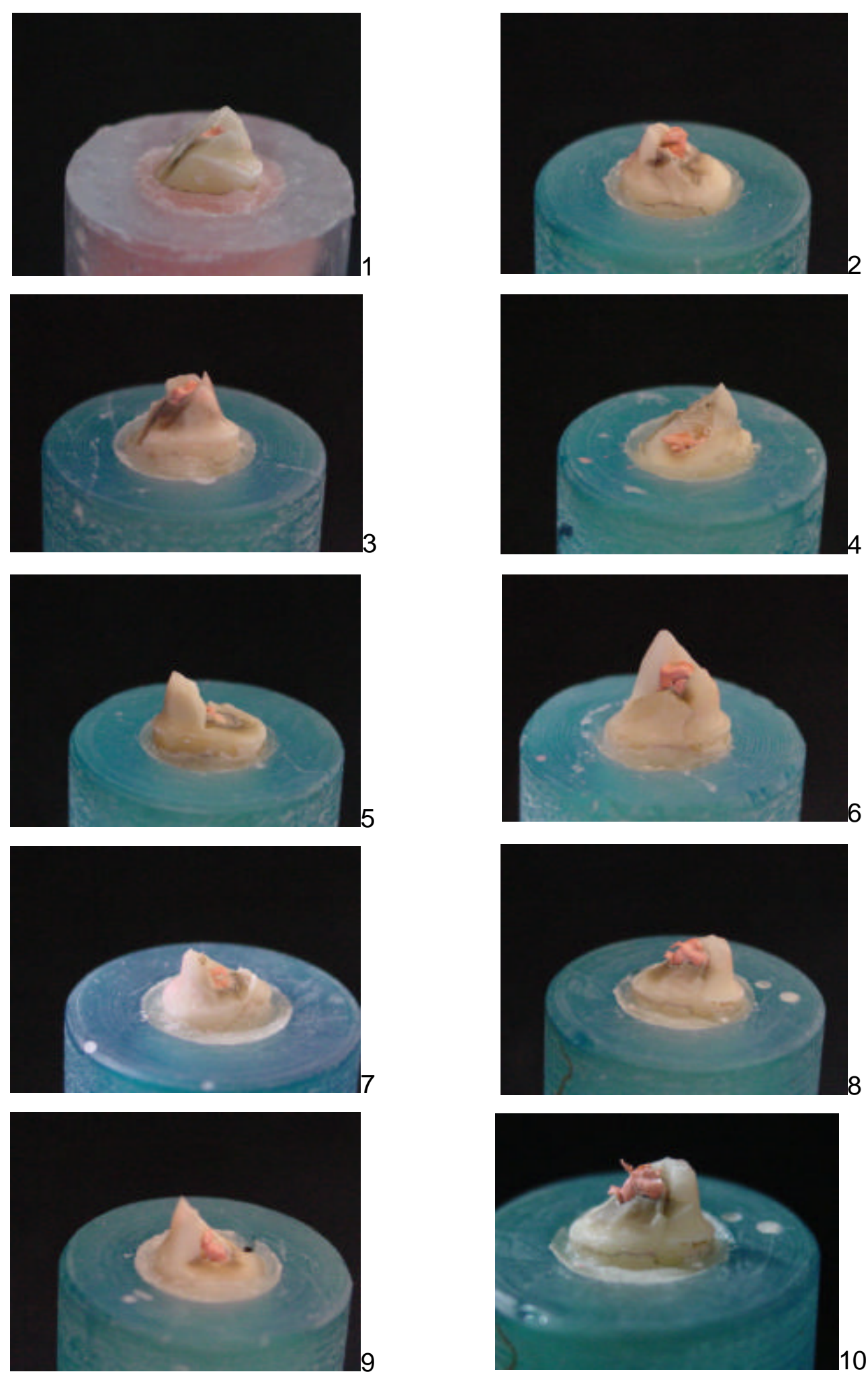

Figura 10: Sem pino intra-radicular 

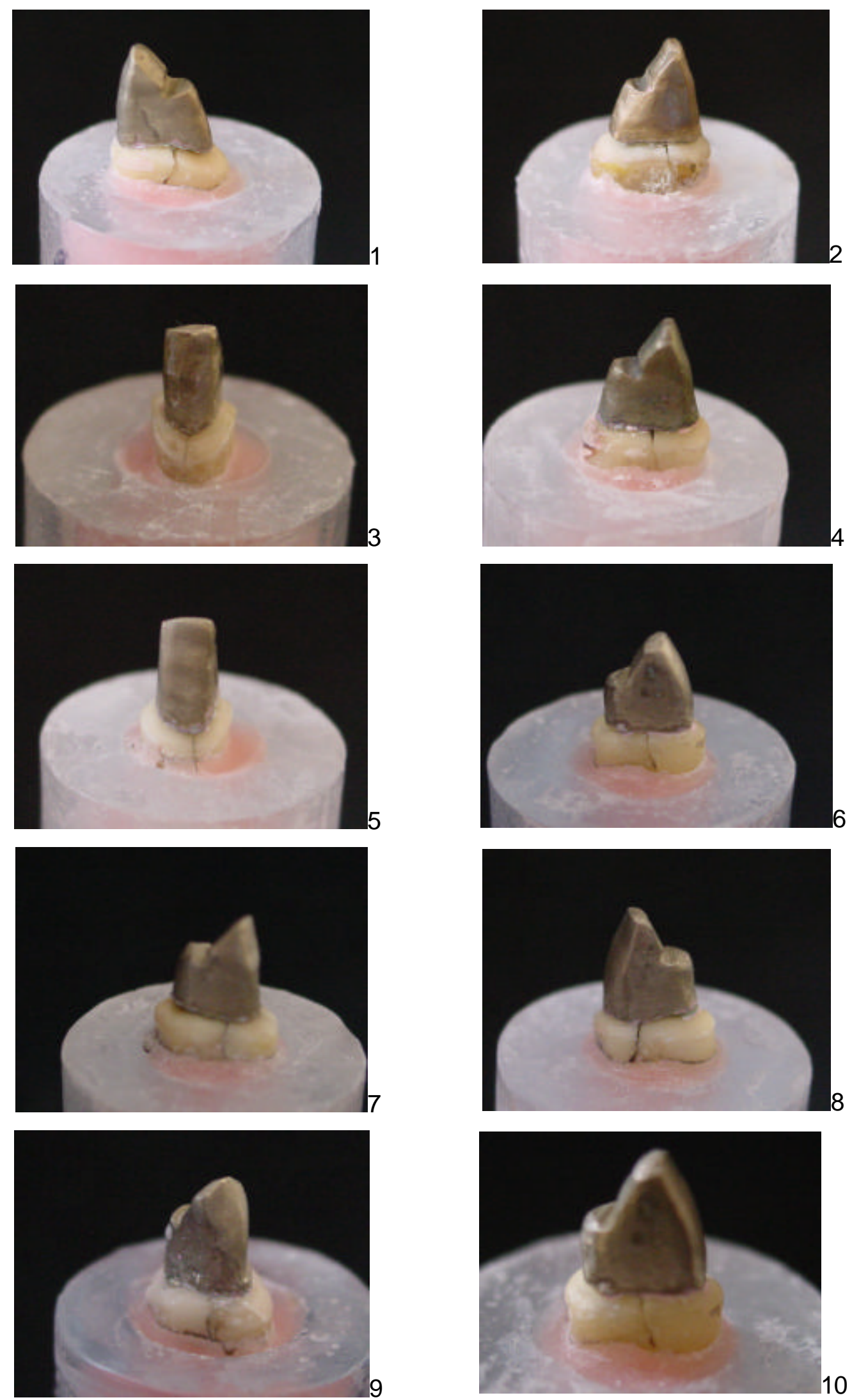

FIGURA 11: Núcleo metálico fundido 

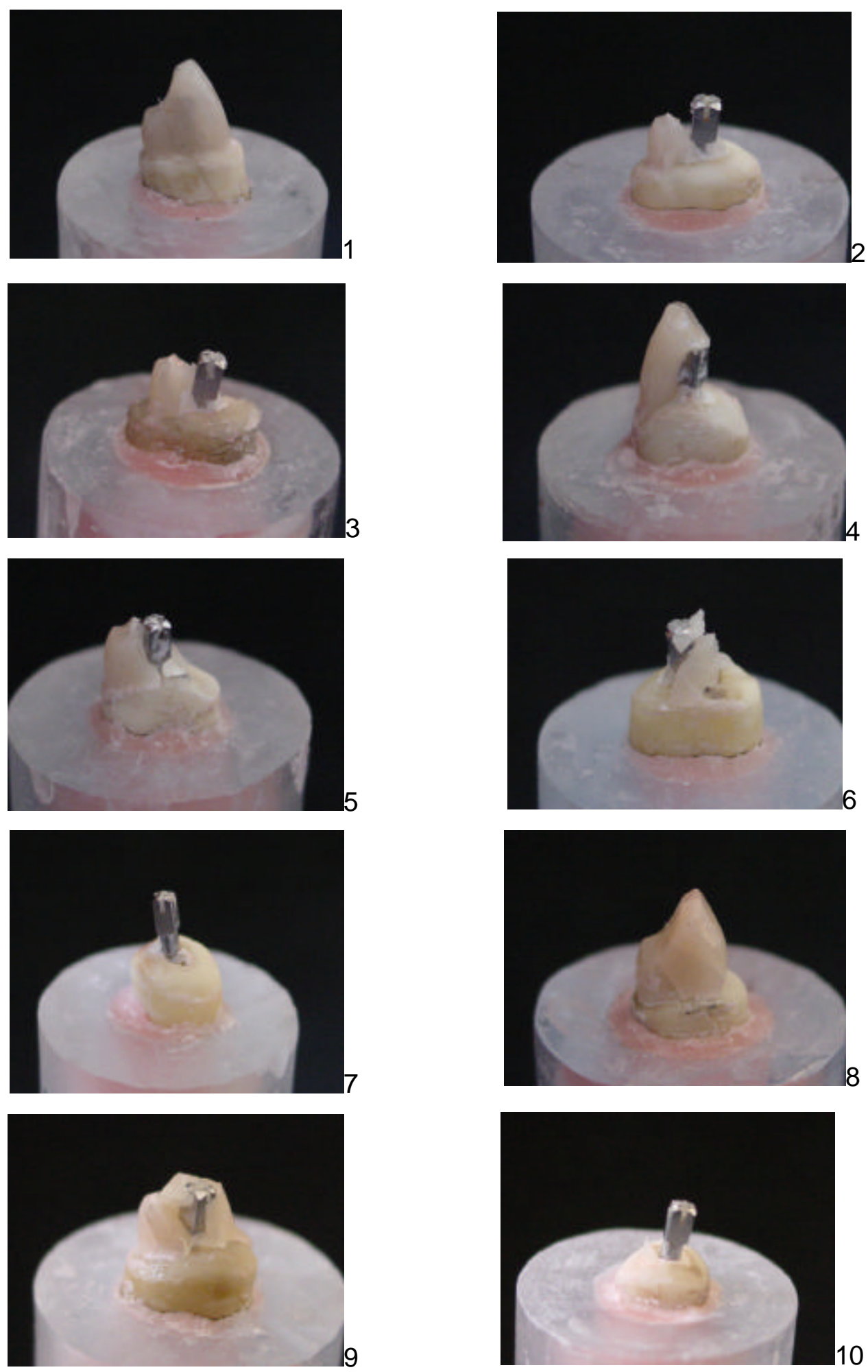

Figura 12: Pino pré-fabricado sem remanescente coronal 

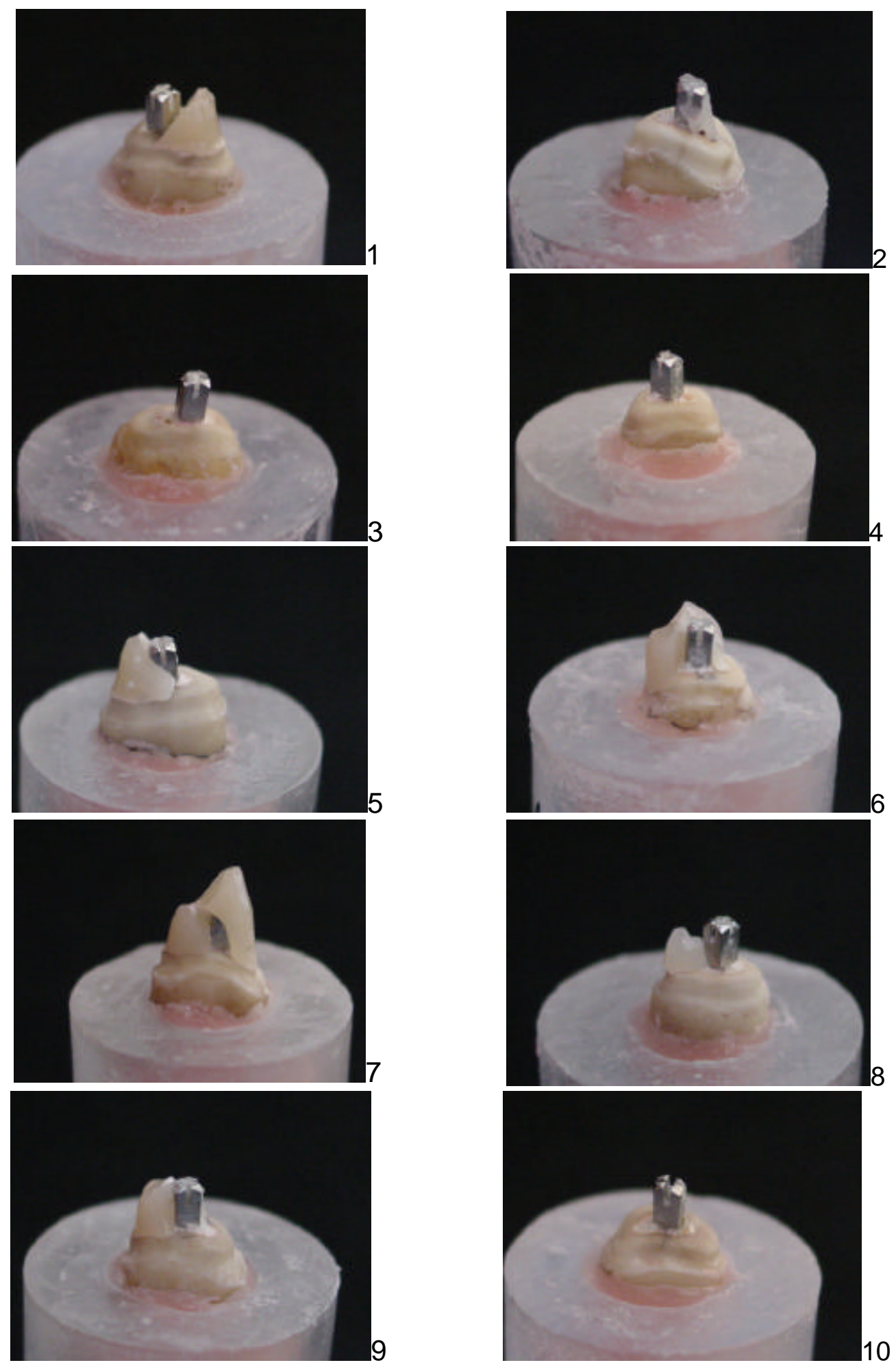

FIGURA 13: Pino pré-fabricado com $1 \mathrm{~mm}$ de remanescente coronal 

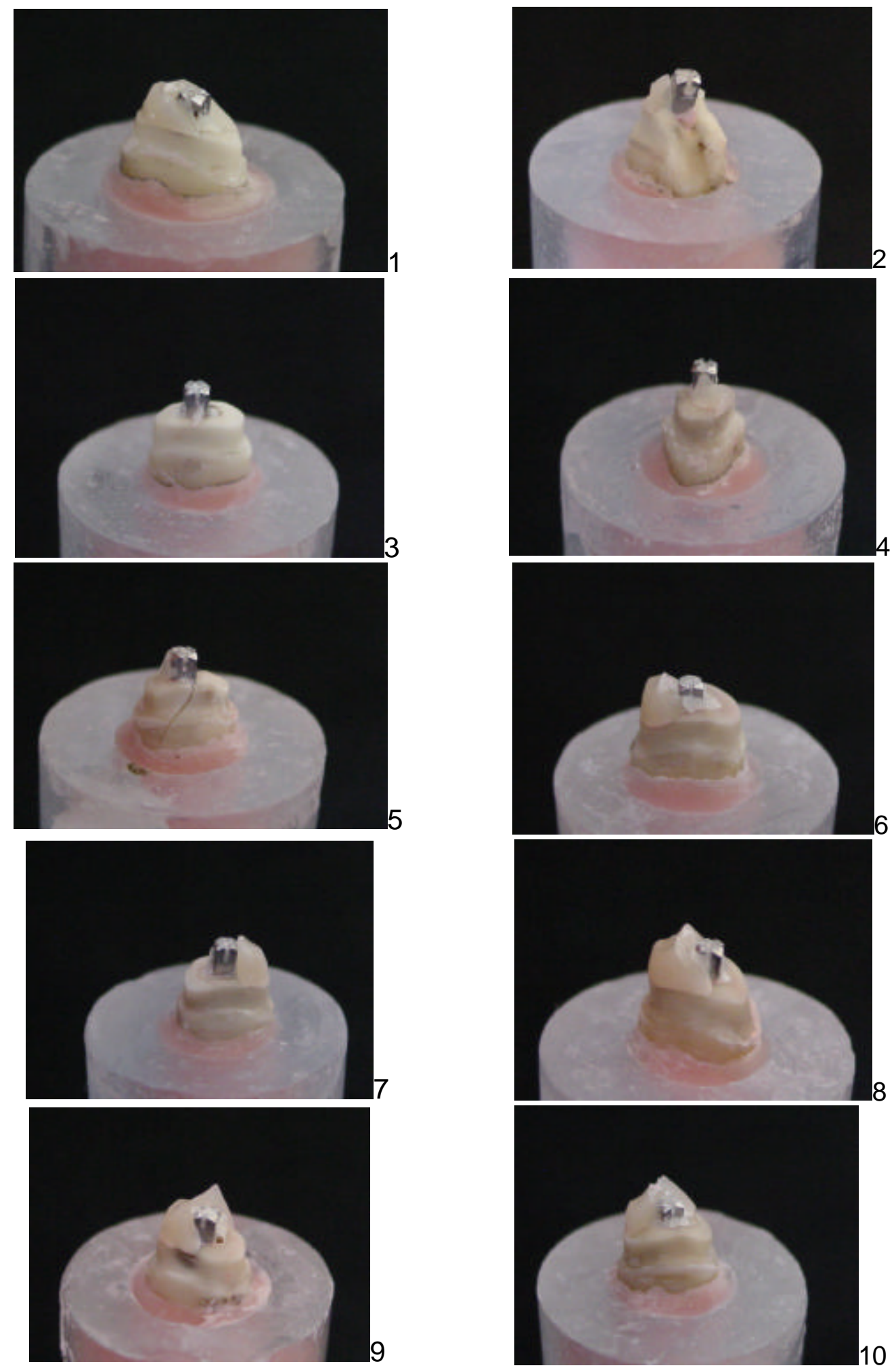

FIGURA 14: Pino pré-fabricado com $2 \mathrm{~mm}$ de remanescente coronal 

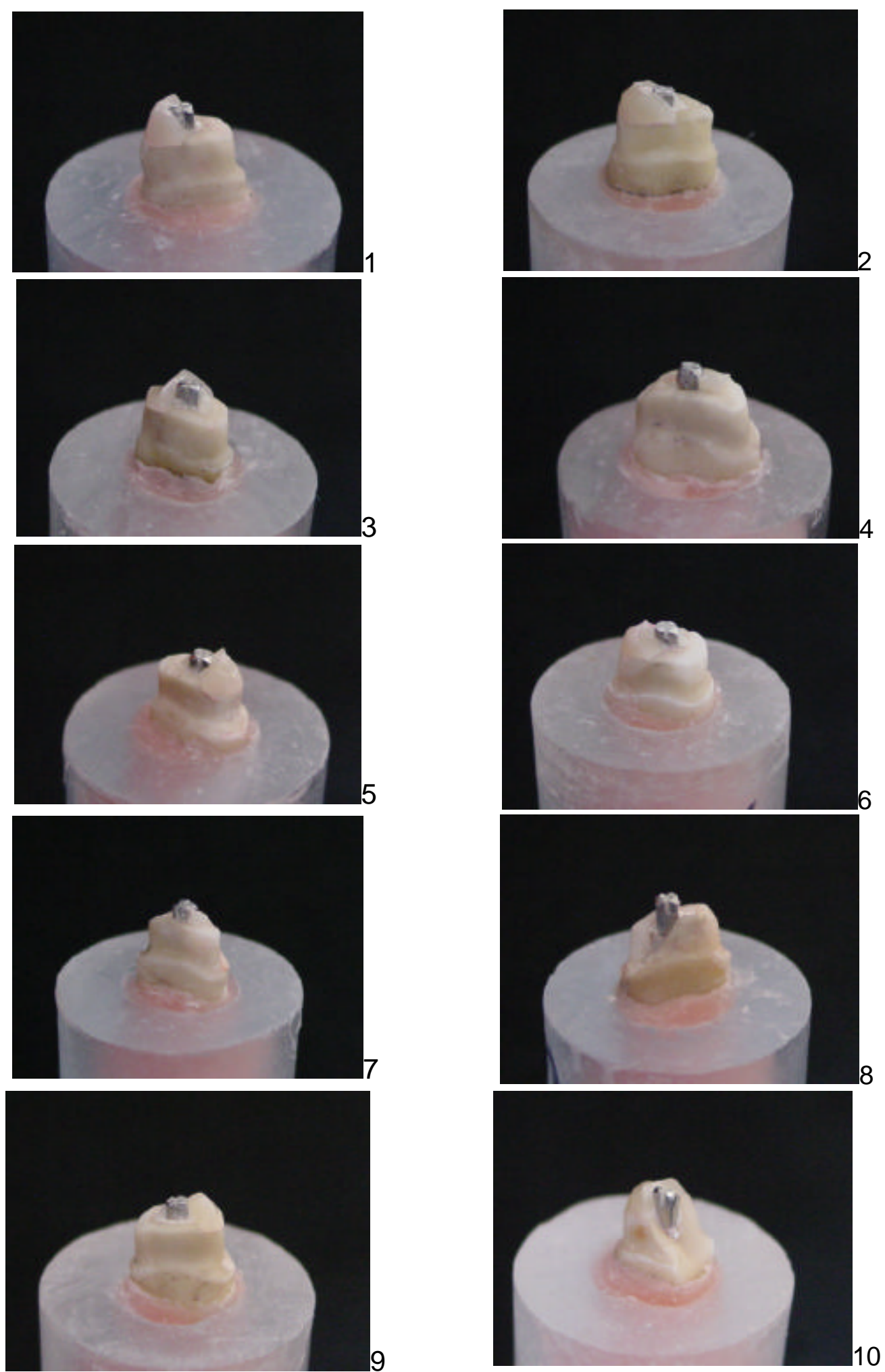

FIGURA 15: Pino pré-fabricado com 3mm de remanescente coronal 
REFERÊNCIAS

\section{BIBLIOGRÁFICAS}




\section{REFERÊNCIAS BIBLIOGRÁFICAS*}

1. ABDALLA, A. I.; ALHADAINY, H. A. 2-years clinical evaluation of class I posterior composites. Amer. J. Dent., v. 9, n.4, p.150-2, Aug. 1996.

2. AKKAYAN, B.; CANIKLIOGLU, B. Resistance to fracture of crowned teeth restored with different post systems. Eur. J. Prosthodont Rest. Dent., v.6, n.1, p.13-8, 1998.

3. AKKAYAN. B. et al. Resístanse to fracture of endodontically treated restored with different post systems. J. prosth. Dent., v.87,n.4, p.431-7, Apr. 2002.

4. ASSIF, D. et al. Photoelastic analysis of stress transfer by endodontically treated teeth to the supporting structure using different restorative techniques. J. prosth. Dent., v.61, n.6, p.6768, Jan. 1989.

5. ASSIF, D.; GORFIL, C. Biomechanical considerations in restoring endodontically treated teeth. J. prosth. Dent., v.71, n.6, p.565-7, June 1994.

6. BAHARAV, $\mathrm{H}$. et al. Effect of irradiation time on tensile properties of stiffness and strength of composites. J. prosth. Dent., v.77, n.5, p.471-4, May 1997.

\footnotetext{
* Normas recomendadas para utilização no âmbito da Universidade de São Paulo, com base no documento "Referências Bibliográficas: exemplos", emanado do Conselho Superior do Sistema Integrado de Bibliotecas da USP.
} 
7. BAKER, C. F. The dowel crown. J. Amer. dent. Ass., v.61, p.479-83, 1960.

8. BALASSIANO, D. F. Contribuição ao estudo dos núcleos metálicos cimentados. Rev. bras. Odont., v.194, p.140-55, 1975.

9. BARABAN, D. J. A simplified method for making posts and cores. J. prosth. Dent., v.24, n.3, p.287-97, Sept. 1970.

10. BARABAN, D. J. Immediate restoration of pulpless teeth. J. prosth. Dent., v.28, n.6, p.607-12, Dec. 1972.

11. BARABAN, D. J. The restoration of endodontically treated teeth: an update. J. prosth. Dent., v.59, n.5, p.553-8, May 1988.

12. BARATIERI, L. N. Influence of post placement in the fracture resistance of endodontically treated incisors veered with direct composite. J. prosth. Dent., v.84, n.2, p.180-4, 2000.

13. BARKHORDAR, R. A.; RADKE, R.; ABBASI, J. Effect of metal collars on resistance of endodontically treated teeth to root fracture. J. prosth. Dent., v.61, n.6, p.676-8, June 1989.

14. BENDER, I. B.; FREEDLAND, J. B. Adult root fracture. J. Amer. dent. Ass., v.107, n.3, p.413-9, Sept. 1983.

15. BERGMAN, B. et al. Restorative and endodontic results after treatment with cast and cores. J. prosth. Dent., v.61, n.1, p.10-5, 1989. 
16. BEX, R.T. et al. Effect of dentinal bonded resin post-core preparations on resístanse to vertical fracture . J. prosth. Dent., v.67, n.1, p.768-72, 1992.

17. BLACK, G. V. A method of grafting artificial crowns on roots of teeth. Mo. Dent. J., v.1, p.233, 1869.

18. BRANDALL, J. L.; NICHOLLS, J. I.; HARRINGTON, G. W. A comparison of three restorative techniques for endodontically treated anterior teeth. J. prosth. Dent., v.58, n.2, p.161-5, 1987.

19. BRAVIN, R. V. Post reinforcement tested. The Functional stress analysis of post reinforcement. J. Calif. dent Ass., v.4, p.66-96, 1976.

20. BRECKER, S. C. Crowns. Philadelphia, Saunders, 1961. p.417-24.

21. CAIlleteAU, J. G.; RIEGER, M. R.; AKIN, E. D. A comparison of intracanal stresses in a post-restored tooth utilizing fuüte element method. J. Endod., v.18, n.11, p.540-4, Nov. 1992.

22. CAPUTO, A. A.; STANDlEE, J. P. Pins and posts-why, when and how. Dent. Clin. N. Amer., v.20, n.2, p.299-311, Apr. 1976.

23. CARDOSO, P. E. C.; POSKUS, L.T. Evaluation of microleakage and vickers microhardness of condensable composite resins. Abstract.n.362 J. dent. Res., v. 79,p.189,2000. Special issue.

24. CHAN, R. W.; BRYANT, R. W. Post-core foundations for 
endodontically treated posterior teeth. J prosth. Dent., v.48, n.4, p.401, Oct. 1982.

25. CHANG, W. C.; MILLSTEIN, P. L. Effect of design of prefabricated post heads on core materials. J. prosth. Dent., v.69, n.5, p.47582, 1993.

26. CHARLTON, G. A., A prefabricated post and core for porcelain jacket crowns. Brit. dent. J., v.119, n.10, p.452-6, Nov., 1965.

27. CHRISTENSEN, G. J. Posts: necessary or unnecessary? J. Amer. dent. Ass., v.127, p.1522-8, Oct. 1996.

28. CHRISTIAN, G. W. et al. Post core restoration in endodontically treated posterior teeth. J. Endod., v.7, p.182-5, 1981.

29. CHRISTY, J. M.; PIPKO, D. J. Fabrication of a dual-post veneer crown. J. Amer. dent. Ass., v.75, n.6, p.1419-25, Dec. 1967.

30. COHEN, B. I. et al. Fracture strength of three different core materials in combination with three different endodontic posts. Int. J. prosth. Odont., v.7, p.178-82, 1994.

31. COHEN, B. I. et al. Four different core materials measured for fracture strength in combination with five different designs of endodontic posts. J. prosth. Dent., v.76, n.5, p.487-95, Nov. 1995.

32. COHEN, B. I. et al. Comparison of torsional forces at failure for seven endodontic post systems. J. prosth. Dent., v.74, n.4, p.350-7, 
1996.

33. COHEN, B. I. et al. Pilot study comparing the photoelastic stress distribution for four endodontic post systems. J. oral. Rehab., v.23, p.679-85, Nov. 1996.

34. COHEN, B. I. et al. Fracture strengths of three core restorative materials supported with or without a pre- fabricated split- shank post . J. prosth. Dent., v.78, n.6, p.560-4, 1997.

35. DALE, J. W.; MOSER, J. A clinical evaltuation of semiprecious alloys for dowels and cores. J. prosth. Dent., v.38, n.2, p.161-4, Aug. 1977.

36. DERAND, T. The principal stress distribution in a roof with a loaded post in model experiments. J. dent. Res., v.56, n.12, p.1463-7, Dec. 1977.

37. DEUTSCH, A. S. et al. Prefabricated dowels: A literature review. J. prosth. Dent., v.49, n.4, p.498-503, Apr. 1983.

38. DEUTSCH, A. S. et al. Root fracture and the design of prefabricated posts. J. prosth. Dent., v. 53, n.1, p.12-4, Jan. 1985.

39. ECKERBOM, M.; MAGNUSSON, T. Restoring endodontically treated teeth: a survey of current opinions among board-certified prosthodontics andgeneral dental practitioners in Sweden. Int. J. Prosthodont., v.14, n.3 p.245-9, 2001. 
40. FAUCHARD, P. Le chirurgien dentisté on traité des dents. 10. ed. Paris, Julien Prélat, v.2, p.244-56, 1946.

41. FEDERICK, D. R. An application of the dowel and composite resin core technique. J. prosth. Dent., v.32, n.4, p.420-4, Oct. 1974.

42. FERNANDES, A. S.; DESSAI, G. S. Factors affecting the fracture resistance of post-core reconstructed teeth: a review.. Int. J. Prosthodont., v.14, n.4, p.355-63, 2001.

43. FRAGA, R. C. et al. Fracture resistance of endodontically treated roots after restoration. J. oral Rehab., v.25, n.11, p.809-13, Nov. 1998.

44. FRANK, A. L. Protective coronal coverage of the pulpless tooth. J. Amer. dent. Ass., v.59, p.895-900, Nov. 1957.

45. FUSAYAMA, T; MAEDA, T. Effect of pupectomy on dentin hardness. J. dent. Res., v.48, n.3, p.452-60, May/June 1969.

46. GEGAUFF, A. G. Effect of crown lengthening and ferrule placement on static load failure of cemented cast post-cores and crowns. J. prosth. Dent., v.84, p.169-79, 2000.

47. GELFAND, M.; GOLDMAN, M.; SUNDERMAN, E. J. Effect of complete veneer crowns on the compressive strength of endodontically treated posterior teeth. J. prosth. Dent., v. 52, p.635-8,1984.

48. GREENFELD, R. S.; MARSAHALL, F. J. Factors affecting dowel 
(post) selection and use in endodontically treated teeth. J. Canad. dent. Ass., v.49, n.11, p.777-83, Nov. 1983.

49. GUTTMAN, J. L. Preparation of endodontically treated teeth to receive a post-core restoration. J. prosth. Dent., v.38, n.4, p.4139, Oct. 1977.

50. GUTMANN, J. L. The dentin-root complex: anatomic and biologic considerations in restoring endodontically treated teeth. J. prosth. Dent., v.67, n.4, p.458-67, Apr. 1992.

51. GUZY, G. E.; NICHOLLS, J. I. "In vitro" comparison of intact endodontically treated teeth with and without endo-post reinforcement J. prosth. Dent., v.42, n.1, p.39-44, July 1979.

52. HARRIS, F. L. An efficient one visit impression technique for goldpost and cast crown fabrication. Dent. Digest., v.76, n.11, p.4646, Nov. 1970.

53. HARTY, F.J.; LEGGETT, L. J. A post crown technique using a nickelcobalt-chromium post. Brit. dent. J., v.132, n.10, p.394-8, May 1972.

54. HATZIKYRIAKOS, A. H.; REISIS, G. I.; TSINGOS, N. A 3-year postoperative clinical evaluation of posts and cores beneath existing cronws. J. prosth. Dent., v.67, n.4, p.454-8, 1992.

55. HENRY, P. J. Photoelastic analysis for post core restorations. Aust. dent. J., v.22, n.3, p.157-9, June 1977. 
56. HENRY, H. W. et al. Fracture behavior of human mandibular incisors following endodontic treatment and porcelain veneer restoration. Int. J. Prosthodont., v.14, n.3, p.260-4, 2001.

57. HEYDECKE, G.; PETERS, M. C. The restoration of endodontically treated, single-rooted teeth with cast or direct posts and cores: a systematic review. J. prosth. Dent., v.87, n.4, p.380-6, Apr. 2002.

58. HO, M. H. Three-dimensional finite element analysis of the effects of posts on stress distribution in dentin. J. prosth. Dent., v.72, n.4, p.367-72, Oct. 1994.

59. HOAG, E. P.; DWYER, T. G. A comparative evaluation of three post and core techniques. J. prosth. Dent., v.47, n.2, p.177-81, Feb. 1982.

60. HOLMES, D. C.; DIAZ-ARNOLD, A. M.; LEARY, J. M. Influence of post dimension on stress distribution in dentin. J. prosth. Dent., v.75, n.2, p.140-7, Feb. 1996.

61. HOLT, J. K. Anterior post crowns. Brit. dent. J., v.113, n.9, p.299301, 1962.

62. HUANG, T. G.; SCHILDER, H.; NATHANSON, D. Effects of moisture content and endodontic treatment on some mechanical properties of human dentin. J. Endod., v.18, n.5, p.209-25, May. 1992.

63. HUNTER, A. J.; FEIGLIN, B.; WILLIAS, J. F. Effects of a post placement on endodontically treated teeth. J. prosth. Dent., v.62, 
n.8, p.166-72, Aug. 1989.

64. IRVIN, A. W. et al. Photoelastic analysis of stress induced from insertion of self-threading retentive pins. J. prosth. Dent., v.53, p.311-6, 1985.

65. ISHIKIRIAMA, A. et al. Resistência à fratura de dentes tratados endodonticamente e restaurados com resina composta. Rev. Fac. Odont. Bauru, v.3, n.1/4, p.47-52, jan/dez. 1995.

66. ISIDOR, F.; BRONDUM, K.; RAVNHOLT, G. The influence of post length and crown ferrule on the resistance to cyclic loading of bovine teeth prefabricated titanium post. Int. J. Prosthodont., v.12, n.1, p.79-82, 1999.

67. JOHNSTON, J. F. et al. Crown and brigde prosthodontics. 2.ed. Philadelphia, Saunders, 1965. p.531-5

68. JOHNSON, J. K.; SCHWARTZ, N. L.; BLACKWELL. R. T. Evaluation and restoration of endodontically treated posterior teeth. J. Amer. dent Ass., v.93, n.3, p. 597-605, Sept. 1976.

69. KAHN, F. H. Selecting a post system. J. Amer. dent. Ass., p.70-1, Dec. 1991.

70. KAHN, F. H. et al. Comparison of fatigue for three prefabricated threaded post systems. J. prosth. Dent., v.75, n.2, p.148-53, Feb. 1994. 
71. KANTOR, M. E.; PINES, M. S. A. Comparative study of restorative techniques for pulpless teeth. J. prosth. Dent., v.38, n.4 p.405412, Oct. 1977.

72. KAYSER, A. F.; LEEMPOEL, P. J. B.; SNOEK, P. A. The metal post and composite core combination. J. oral. Rehab., v.14, n.1 p.3$11,1987$.

73. KEYF, F.; SAHIN, E. Retentive properties of three post-core systems. Aust. dent. J., v.39, n.1, p.20-4, Jan. 1994.

74. KING, P. A.; SETCHELL, D. J. Analisys in vitro evaluation of a prototype CFRC prefabricated post developed for the restoration of pulpless teeth. J. oral Rehab., v.39, n.1, p.599-609, 1990.

75. KORNFELD, M. Mouth rehabilitation. Clinical and laboratory procedures. 2. ed., St Louis, 1974. v.1, p.386-92

76. KURER, P. F. Retention of post crowns. A solution of the problem. Brit. dent. J., v.123, n.4, p167-9, 1967.

77. KURER, H. G. et al. Factors influencing the retention of dowels. J. prosth Dent., v.38, p515-25, 1977.

78. LEARY, J. M.; AQUILINO-ASSWARE, C. W. An evaluation of post strength within the elastic limits of dentin. J. prosth. Dent., v.57, p.277-81, 1987.

79. LEVARTOVSKY, S. et al. A comparison of the diametral tensile 
strength, the flexural strength, and the compressive strength of two new core materials to a silver alloy-reinforcedglass-ionomer material. J. prosth. Dent., v.72, p.481-5, 1994.

80. LINDHE, L. A. The use of composites as core material in root-filled teeth. Swed. dent. J., v.8, p.209-16, 1984.

81. LINDHE, L. A. The use of composite resins in combination with anchorage posts as core material in endodontically treated teeth: clinical aspects of the technique. Quintessence Int., v.24, n.2, p.115-22, Feb. 1993.

82. LONEY, R. W.; KOTOWICS, W. E.; McDOWELL, G. C. Threedimension photoelastic stress analysis of the ferrule effect in cast post and cores. J. prosth. Dent., v.63, n.5, p.506-46, 1990.

83. LYONS, M. F. A preliminary electromyographic study of bite force and jaw-closing muscle fatigue in human subjects with advanced tooth wear. J. oral Rehab., v.17, p.311-8, 1990.

84. MANNING, K. E. et al. Factors to consider for predictable post and core build-ups of endodontically treated teeth. Part I: basic theoretical concepts. J. Canad. dent. Ass., v.61, n.8, p.685-95, Aug. 1995.

85. MANNING, K. E. et al. Factors to consider for predictable post and core build-ups of endodontically treated teeth. Part II: clinical application of basic concepts. J. Canad. dent. Ass., v.61, n.8, p.696-706, Aug. 1995. 
86. MARCHI, G. M. Resistência à fratura de raízes debilitadas reconstruídas morfologicamente com sistema adesivo e pinos intra-radiculares. Piracicaba 1997, 106p. Dissertação (Mestrado) Faculdade de Odontologia de Piracicaba, UNICAMP.

87. MARKLEY, M. R. Pin reinforcement and retention of amalgam foudations and restorations. J. Amer. dent. Ass., v.55, p.675-9, 1958.

88. MARTINEZ-INSUA, A. et al. Comparison of fracture resistances of pulpless teeth restored wth a cast post and core or carbon-fiber post with a composite core. J. prosth. Dent., v.80, n.5, p.527-32, Nov. 1998.

89. MATTISON, G. D. Photoelastic stress analysis of cast-gold endodontic posts. J. prosth. Dent., v.48, n.4, p.407-11, Oct. 1982.

90. Mc DONALD, A. V.; KING, P. A.; SETCHELL, D. J. An "in vitro" study to compare impact fracture resistance of intact root-treated teeth. Int. Endod. J., v.23, p.304-12, 1990.

91. McLEAN, A. Criteria for predictably restorable endodontically treated tooth. J. Canad. dent. Ass., v.64, n.9, p.652-6, Oct. 1998.

92. MCLEAN, A. Predictability of restoring endodontically trated teeth. J. Canad. dent. Ass., v.64, n.11, p.782-7, Dec. 1998.

93. MILLER, A. W. Direct pattern techinique for post and cores. J. prosth. Dent., v.40, n.4, p.319-27, 1978. 
94. MILLER, A. W. Post and core systems: which one is the best? J. prosth. Dent., v.48, p.27-38, 1982.

95. MILOT, P.; STEIN, S. Root fracture in endodontically treated teeth related to post selection and crown design. J. prosth. Dent., v.68, n.3, p.428-35, Sept. 1992.

96. MONDELLI, J. et al. Fracture strength of human teeth with cavity preparations. J. prosth. Dent., v.43, n.4, p.419-22, Apr. 1980.

97. MORGANO, S.; MILOT, P. Clinical success of cast metal post and cores. J. prosth. Dent., v.69, n.1, p.11-6, 1993.

98. MORGANO, S. M. Restoration of pulpless teeth: application of traditional principles in present and future contexls. J. prosth. Dent., v.75, n.4, p.375-80, Apr. 1996.

99. MORGANO, S. M.; BRACKETT, S. E. Foundation restorations in fixed prosthodontics: current knowledge and future needs. J. prosth. Dent., v.82, n.6, p.643-57, Dec. 1999.

100. MOYERS, R. E. Handbook of orthodontics. 3.ed. Chicago, YBMP, 1975. 778p.

101. NEAGLEY, R. L. The effect of dowel preparation on $h$ apical seal of endodontically treated teeth. Oral Surg., v.28, n.5, p.739-45, Nov. 1969.

102. OLIVEIRA, F. C.; DENEHY, G. E.; BOYER, D. B. Fracture resistance 
of endodontically prepared teeth using various restorative materials. J. Amer. dent. Ass., v.115, n.7, p.57-60, July 1987.

103. PAO, Y. C. et al. Roof stresses with tappered end post design in periodontally compromised teeth. J. prosth. Dent, v.57,n.3, p.2816, Mar. 1987.

104. PAULILLO, L. A. M. S. Influência da retenção intra-radicular na resistência de dentes tratados endodonticamente. Piracicaba, 2001. Tese (Livre docência) Faculdade de Odontologia de Piracicaba, UNICAMP.

105. PEGORARO, L. F. et al. Núcleos. In: Prótese fixa. São Paulo, Artes Médicas, 1998. p-85-110.

106. PEREL, M. L.; MUROFF, F. I. Clinical criteria for posts and cores. J. prosth. Dent., v.28, n.4, p.405-11, Oct. 1972.

107. PETERS, M. C. R. B. et al. Stress analysis of a tooth restored with a post and core. J. dent. Res., v.62, n.2, p.760-3, June 1983.

108. PEUTZFELD, A.; ASMUSSEN, E. Flexural and fatigue strengths of root canal posts. Scand. J. dent. Res., v.98, p.550-7, 1990.

109. PIERRISNARD, L. et al. Corono-radicular reconstructionof pulpless teeth. A mechanical study using finite element analysis. J. prosth. Dent., v.88, p.442-8, 2002

110. PILO, R. Residual dentin thickness in mandibular premolars prepared 
withgatesglidden and ParaPost drills. J. prosth. Dent., v.83, n.6, p.617-23, June 2000.

111. PLASMANS, P. J. J. M. et al. "In vitro" comparison of dowel and core techniques for endodontically treated molars. J. Endod., v.12, p.382-7, 1986.

112. PLASMANS, P. J. J. M. et al. "In vitro" resistance of composite resin dowel and cores. J. Endod., v.14, p.300-4, 1988.

113. RADKE, R. A.; BARKHODAR, R. A.; PODESTA, R. E. Retention of cast endodontic posts: comparison of cementing agents. J. prosth. Dent., v.59, n.3, p.318-20. Mar. 1988.

114. RAYGOT, C. G. Fracture resistance and primary failure mode of endodontically treated teeth restored with a carbon fiber-reinforced resin post system In vitro. Int. J. Prosthodont., v.14, n.2, p.141-5, 2001.

115. REAGAN, S. E. et al. Effects of cyclic loading on selected post and core systems. Quintessence Int., v.30, n.1, p.61-7, 1999.

116. REIS, F. N. Preparo e moldagem dos condutos radiculares. Dente uni e multirradiculares. Características do preparo radicular e do núcleo metálico. Bauru, 1976. Dissertação (Mestrado) Faculdade de Odontologia de Natal.

117. ROBBINS, J. W. Guidelines for the restoration of endodontically treated teeth. J. Amer. dent. Ass., v.120, n.5, p.558-66, May 
1990.

118. ROBBINS, J. W. et al. Fracture resistance of endodontically treated cuspids . J. Amer. dent. Ass., v.6, n.1, p.159-61, 1993.

119. ROLF, K. C.; PARKER, M. W.; PELLEU, G. B. Stress analysis of five prefabricated endodontic dowel designs: a photoelastic study. Oper. Dent., v.17, p.86-72, May/June 1992.

120. ROSEN, H. Operative procedures on mutilated endodontically treated teeth. J. prosth. Dent., v.11, p.973-86, 1961.

121. RUEGGEBERG, F. A.; CAUGHMAN, W. F.; CURTIS JR., J. W. Effect of light intensity and exposure duration on cure of resin composite. Oper. Dent., v.19, p.26-32, 1994.

122. RUSSI, S.; LEONARDI, P. Verificação radiográfica de alguns princípios relacionados às coroas com pino. Rev. Fac. Farm. Odont. Araraquara, v.2, p.161-8, 1968.

123. SANTOS, M. J. C. M.; SILVA E SOUZA JUNIOR., M. H.; MONDELLI, R. F. L. Novos conceitos relacionados à fotopolimerização das resinas compostas. J.B.D., v.1, n.1, jan./mar. 2002.

124. SCHIMIDT, J. R. et al. A single visit post and core procedure. N. Y. St. Dent. J., v.39, n.10, p.604-10, Dec. 1973.

125. SEDGLEY, C. M.; MESSER, H. H. Are endodontically treated teeth more brittle? J. Endod., v.18, n.7, p.332-5, July 1992. 
126. SEGAT, L. The restoration of non-vital teeth. J. Mich. dent. Ass., v.44, p.254-9, 1962.

127. SHEETS, C. E. Dowel and core foundations, J. prosth. Dent, v.23, n.1, p.58-65, Jan. 1970.

128. SHILLINBURG JUNIOR, H. T.; FISCHER, D. W.; DEWHIRST, R. B. Restoration of endodontically treated posterior teeth. J. prosth. Dent, v.24, n.4, p.401-9, Oct. 1970.

129. SICKELMORE, F. A. Post crows - some weakness. Brit. dent. J., v.107, p.306-8, 1959.

130. SIDOLI, G. E.; KING, P. A.; SETCHELL, D. J. An "in vitro" evaluation of carbon fiber-based post and core system. J. prosth. Dent., v.78, n.1, p.5-9, July 1997.

131. SILVERSTEIN, W. H. The reinforcement of weakened pulpless teeth. J. prosth. Dent., v.14, p.372-81, 1964.

132. SIRIMAI, S.; RIIS, D.N.; MORGANO, S. M. An "in vitro" study of the fracture resistance and the incidence of vertical root fracture of pulpless teeth restored with six post-and-core systems. J. prosth. Dent., v.81, n.3, p.262-9, Mar. 1999.

133. SMITH, C. T.; SCHUMAN, N. Restoration of endodontically treated teeth: guide for the restorative dentist. Quintessence Int., v.28, n.7, p.457-62, 1997. 
134. SMITH, C. T.; SCHUMAN, N. J.; WASSON, W. Biomechanical criteria for evaluating prefabricated post-and-core systems: aguide for the restorative dentist. Quintessence Int., v.29, n.5, p.305-12, May 1998.

135. SORENSEN, J. A.; MARTINOFF, J. T. Intracoronal reinforcement and coronal coverage: a study of endodontically treated teeth. J. prosth. Dent., v.51, n.6, p.780-4, June 1984.

136. SORENSEN, J. A.; MARTINOFF, J. T. Clinical significant factors in dowel design. J. prosth. Dent., v.52, n.1, p.28-35, July 1984.

137. SORENSEN, J. A. Preservation of tooth structure. CDA Journal, p.1521, Nov. 1988.

138. SORENSEN, J. A.; ENGELMAN, M. J. Ferrule design and fracture resistance of endodontically treated teeth. J. prosth. Dent., v.63, n.5, p.529-36, May 1990.

139. SORENSEN, J. A.; ENGELMAN, M. J. Effect of post adaptation on fracture resistance of endodontically treated teeth. J. prosth. Dent., v.64, n.4, p.419-24, Oct. 1990.

140. SORENSEN, J. A.; AHN, S. G.; BERGE, H. X.; EDELHOFF, D. Selection criteria for post and core materials in restoration of endodontically treated teeth. Acad. dent mat., p.67-84, 2001.

141. SORNKUL, E.; STANNARD, J. T. Strength of roots before and after endodontic treatment and restoration. J. Endod., v.18, n.9, p.440- 
3, Sept. 1992.

142. SPALTEN, R. G. Composite resin to restore mutilate teeth. J. prosth. Dent., v.25, n.3, p.323-6, Mar. 1971.

143. STACKHOUSE, JUNIOR., J. A. Reinforcement of nonvital crowed teeth. J. Amer. dent. Ass., v.104, p.859-61, June 1982.

144. STANDLEE, J. P.; COLLARD, E. W.; CAPUTO, A. A. Dentinal defects caused by some twist drills and retentive pins. J. prosth Dent., v.24, n.2, p.185-92, Aug. 1970

145. STANDLEE, J. P. et al. Analysis of stress distribution by endodontic posts. Oral Surg., v.33, n.6, p.953-60, June 1972.

146. STERN, N.; HIRSHFELD, Z. Principles of preparing endodontically treated teeth for dowel and core restorations. J. prosth. Dent., v.30, n.2, p.162-5, Aug. 1973.

147. STOCKTON, L. W. Factors affecting retention of post systems: a literature review. J. prosth. Dent., v.81, n.4, p.380-5, Apr. 1999.

148. STOKES, A. N. Post crowns: a review. Int. Endod. J., v.20, p.1-7, 1987.

149. TALEGHANI, M.; MORGAN, R. W. Reconstructive materials for endodontically treated teeth. J. prosth. Dent., v.57, n.4, p.446-9, Apr. 1987. 
150. TALEGHANI, M.; LEINFELDER, K. F. Evaluation of a newglass ionomer cement with silver as a core buildup under a cast restoration. Reconstructive materials for endodontically treated teeth. J. prosth. Dent., v.57, n.4, p.446-9, Apr. 1988.

151. TJAN, A. H. L.; WHANG, S. B. Resistance to root fracture of dowel channels with various thicknesses of buccal dentin walls. J. prosth. Dent., v.53, n.4, p.496-500, Apr. 1985.

152. TORBJORNER, A.; KARLSSON, S.; ODMAN, P. A. Survival rate and failure characteristics for two post designs. J. prosth. Dent., Saint Louis, v.73, n.5, p.439-44, May 1995.

153. TRABERT, K. C.; CAPUT, A. A.; ABOU-RASS, M. Tooth fracture-a comparison of endodontic and restorative treatments. J. Endod., v.4, n.11, p.341-5, Nov. 1978.

154. TROPE, M.; MALTZ, D. O.; TRONSTAD, L. Resistance to fracture of restored endodontically treated teeth. Endod. dent. Traumat., v.1, n.3, p.108-111, June 1985.

155. TROPE, M; RAY JUNIOR, $\mathrm{H}$. Resistence to frature of endodontically treated roots. Oral Surg., v.73, n.1, p.99-102, Jan. 1992.

156. TYLMAN, S. D.; TYLMAN, S. G. Theory and practice of crown and brigde prosthodontics. St. Louis, Mosby, 1960. p.740-83.

157. VALLE, A. L. Avaliação do desajuste vertical, resistência à tração e compressão de núcleos metálicos fundidos, cimentados 
com cimentos de fosfato de zinco e resinoso em condutos tratados ou não com ácido fosfórico . Bauru 2000. 191p. Tese (Livre-Docência) - Faculdade de Odontologia de Bauru , Universidade de São Paulo .

158. WEINE, F. S.; WAX, A. H.; WENCKUS, C. S. Retrospective study of tapered, smooth post systems in place for 10 years or more. J. Endod., v.17, n.6, p.293-7, 1991.

159. YeTtRAM, A. L.; WRIGHT, K. W. J.; PICKARD, H. M. Finite element stress analisys of the crowns of normal and restored teeth. J. dent. Res., v.55, n.6, p.1004-11, 1976.

160. ZALKIND, M.; HOCHMAN, N. Esthetic considerations in restoring endodontically treated teeth with posts and cores. J. prosth. Dent., v.79, n.6, p.702-5, June 1998. 
ABSTRACT 


\section{ABSTRACT}

The aim of this study was to analysed the influence the influence of coronal remainders amounts on the resistence of teeth endodontically treated. For that purpose, sixty anatomically similar upper human canines were selected and divided into six groups with ten specimens each, with the element of group 1 did not receive any post, group 2 restored with cast post and core, and groups 3, 4, 5, 6 with pre-fabricated post and composite core with different amount of coronal dental remainders of $0,1,2,3 \mathrm{~mm}$, respectivally. After restoration the teeth were subjected to compression tests at $45^{\circ}$ in the Universal Test Machine. The assessment of results (ANOVA) showed significant statistical difference amoung the groups. The Tukey test reveiled resistence to fracture values significantilly higher for the cast post and core, followed by the pre-fabricated post with no coronal remainders. The other groups presented lower values much closed amoung each other, thus, showing that the coronal remainders exerts little influence on the resistence of teeth endodontically treated.

Keywords: Resistence, post, core, composite. 